\title{
Summary of Off-Normal Events in US Fuel Cycle Facilities for AFCI Applications
}

Lee C. Cadwallader

Steven J. Piet

Stephen O. Sheetz

David H. McGuire

W. Brent Boore

September 2005

Idaho National Engineering and Environmental Laboratory Bechtel BWXT Idaho, LLC 


\title{
Summary of Off-Normal Events in US Fuel Cycle Facilities for AFCI Applications
}

\author{
Lee C. Cadwallader ${ }^{a}$ \\ Steven J. Piet ${ }^{\mathrm{a}}$ \\ Stephen O. Sheetz \\ David H. McGuire ${ }^{\text {b }}$ \\ W. Brent Boore ${ }^{b}$ \\ adaho National Laboratory \\ ${ }^{\mathrm{b}}$ Westinghouse Savannah River Company
}

September 2005

Idaho National Engineering and Environmental Laboratory Idaho Falls, Idaho 83415

\section{Westinghouse Savannah River Company \\ Aiken, South Carolina 29808}

Prepared for the

U.S. Department of Energy

Office of Nuclear Energy

Under DOE Idaho Operations Office

Contract DE-AC07-05ID14517

and

Savannah River Operations Office

Contract DE-AC06-09-96SR18500 


\begin{abstract}
This report is a collection and review of system operation and failure experiences for facilities comprising the fission reactor fuel cycle, with the exception of reactor operations. This report includes mines, mills, conversion plants, enrichment plants, fuel fabrication plants, transportation of fuel materials between these centers, and waste storage facilities. Some of the facilities discussed are no longer operating; others continue to produce fuel for the commercial fission power plant industry. Some of the facilities discussed have been part of the military's nuclear effort; these are included when the processes used are similar to those used for commercial nuclear power. When reading compilations of incidents and accidents, after repeated entries it is natural to form an opinion that there exists nothing but accidents. For this reason, production or throughput values are described when available. These adverse operating experiences are compiled to support the design and decisions needed for the Advanced Fuel Cycle Initiative (AFCI). The AFCI is to weigh options for a new fission reactor fuel cycle that is efficient, safe, and productive for US energy security.
\end{abstract}




\section{SUMMARY}

This report is a collection of historical data on the US fission fuel cycle facilities, focusing on the incidents and off-normal events that have occurred. These data are useful input to the Advanced Fuel Cycle Initiative (AFCI), which is to weigh options for a new fission reactor fuel cycle that is efficient, safe, and productive for US energy security. Only published reports and papers have been researched; no classified or sensitive data were used during this report preparation.

The intent of this report is to provide a summary of accidents and events that have occurred in the nuclear fuel cycle for use as operating experience feedback to the design of future fuel cycle facilities that support the commercial nuclear power industry. The nuclear fuel cycle is a mixture of industrial processes. Initially, solution mining that produces the uranium feedstock is an industrial process similar to well drilling in the petroleum industry and it has similar hazards of drilling and pumping fluid. Purifying the uranium solution by solvent extraction is a chemical treatment process similar to different types of ore purification performed in other industries and has the hazards inherent with chemical process plants. Uranium enrichment is performed chemically and mechanically, which in principle is similar to the activities and hazards of the chemical process, petroleum, and other industries. During the enrichment step, nuclear criticality safety concerns begin to arise, which is a complication not found in other industries. Fuel pellet and fuel element fabrication is similar to many manufacturing processes that produce large numbers of high precision parts. Fuel fabrication assembly lines, like those in many industries, are partly automated and partly operated by workers. Uranium fuel has very low radioactivity, so the handling concerns dwell mainly on chemical exposure issues and the special concern of nuclear criticality safety. Much of the nuclear industry's initial 1940's facilities at Oak Ridge and Hanford were designed, built and operated by chemical companies under wartime urgency. Some of those facilities were focused on the production goal and were not optimized for protection of the environment or personnel. The commercial facilities that followed incorporated more safety features. This report describes events and accidents that have occurred in each phase of the fuel cycle, and dwells on commercial nuclear fuel cycle facilities but some other experiences are included when they are pertinent for future fuel cycle facilities. Most of these events occurred in the 1950' and 1960's while the industry was young and still recognizing some of the less-obvious hazards. Some of the facilities discussed in this report have either closed in the 1980's or 1990's, or have had their throughput reduced to meet the steady demand for commercial nuclear fuel. The decades of operating experiences provide a solid basis for identifying hazards and implementing safety in the design of future fuel cycle facilities.

Several facts are apparent from this operating experience data review. In the earliest years of solvent extraction operations, the 1950's and 1960's, there were some fires and explosions due to the chemical handling. The number and severity of such 
events have decreased over the decades as the processes have become better understood and plant experiences have shown what collateral hazards can be created during the process operations. Some of the chemicals handled at facilities can pose higher hazard offsite than the nuclear materials; for example, the ammonia and hydrogen fluoride that were used in large quantities for decomposition into hydrogen and fluorine feed materials. Over time, the operations, procedures, and staff knowledge has improved at these facilities so that safety has improved. The industry also decreased from meeting military needs to supplying only the more modest needs of a relatively fixed commercial power industry. Another notable fact is that as the uranium is purified from ore and then enriched, the concern for nuclear criticality increases. The double contingency principle of guarding against criticality by the two means - reducing mass handled and controlling the physical geometry of containment piping, tanks, etc., has in general precluded a number of events. The instances of unanticipated material accumulation in undesignated areas have led to some of the past criticality events.

Noting and making use of these decades of operating experiences from fuel cycle facilities is a prudent action and demonstrates that the AFCI is striving to use best engineering practices in their tasks. Utilizing feedback from field experiences is a fundamental step to improve a design. 


\section{ACRONYMS}

\begin{tabular}{|c|c|}
\hline ADU & ammonium diuranate \\
\hline $\mathrm{AFCI}$ & Advanced Fuel Cycle Initiative \\
\hline DOE & Department of Energy \\
\hline FMPC & Feed Materials Production Center, Fernald, Ohio \\
\hline HEPA & high efficiency particulate air (filter) \\
\hline HEU & highly enriched uranium \\
\hline HW & Hanford Works \\
\hline $\mathrm{ICPP}$ & Idaho Chemical Processing Plant \\
\hline ISL & in situ leaching \\
\hline LEU & low enriched uranium \\
\hline LWR & light water reactor \\
\hline NIOSH & National Institute for Occupational Safety and Health \\
\hline \multicolumn{2}{|c|}{ NMEDNuclear Material Events Database } \\
\hline NRC & Nuclear Regulatory Commission \\
\hline ORGDP & Oak Ridge gaseous diffusion plant \\
\hline PGDP & Portsmouth gaseous diffusion plant \\
\hline PUREX & Plutonium uranium extraction process \\
\hline Recuplex & plutonium waste recovery facility \\
\hline REDOX & Reduction oxide process \\
\hline RWMC & Radioactive Waste Management Complex \\
\hline SAIC & Science Applications International Corporation \\
\hline $\mathrm{SFC}$ & Sequoyah Fuels Corporation \\
\hline
\end{tabular}


TBP tributyl phosphate

UREX Uranium extraction process

USEC United States Enrichment Corporation, Inc. 


\section{TABLE OF CONTENTS}

ABSTRACT

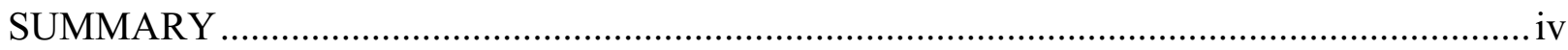

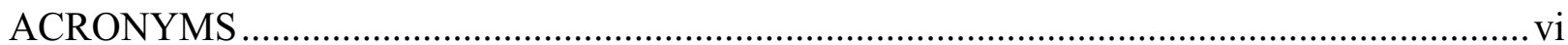

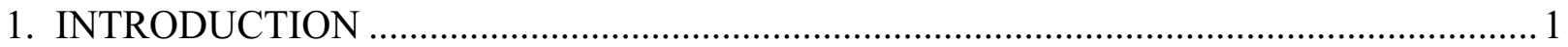

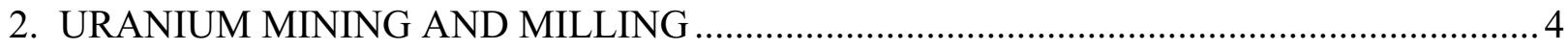

2.1 Uranium Mining............................................................................................. 4

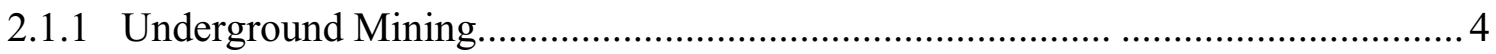

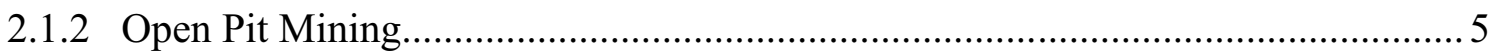

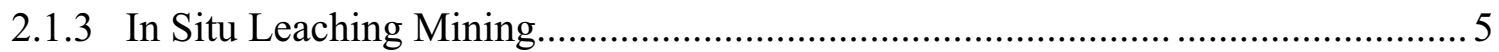

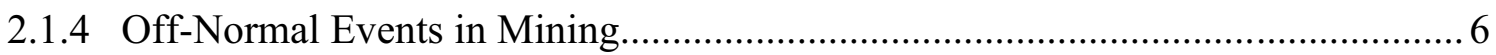

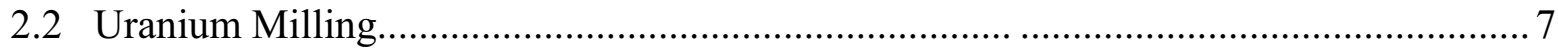

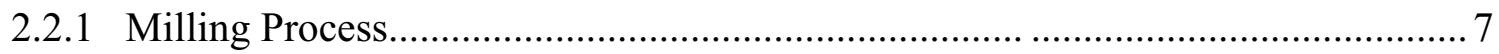

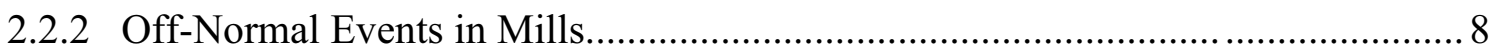

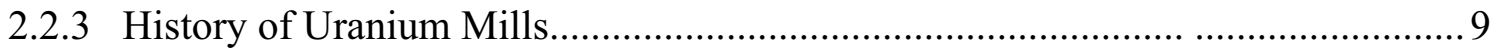

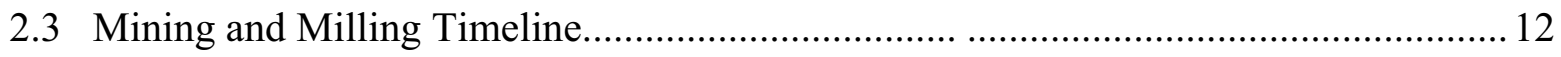

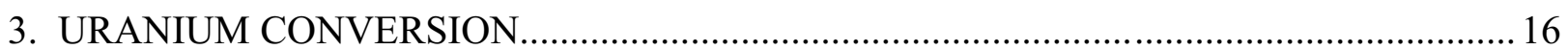

3.1 Brief History and Description of Uranium Conversion.............................................. 16

3.2 Summary of Uranium Conversion Events of Safety Importance................................. 18

3.2.1 Feed Materials Production Center................................................................. 19

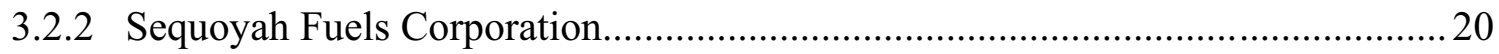

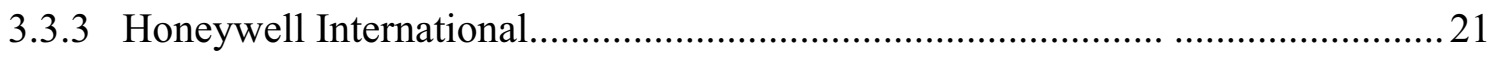

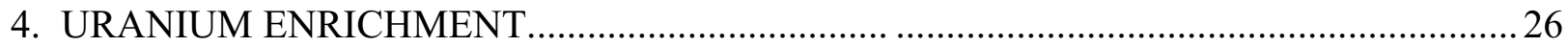

4.1 Brief History and Description of Uranium Enrichment...............................................2 26

4.2 Summary of Uranium Enrichment Events of Safety

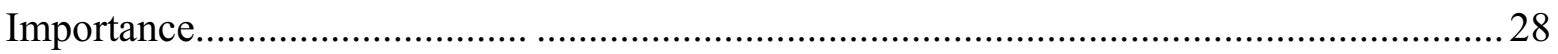

4.2.1 Portsmouth Gaseous Diffusion Plant............................................................. 29

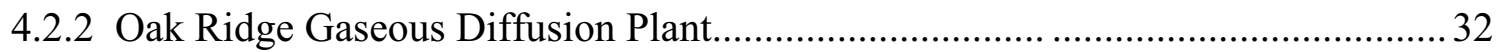

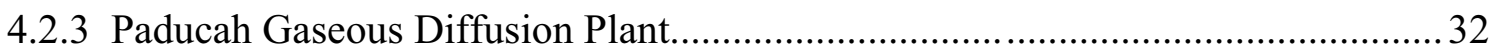

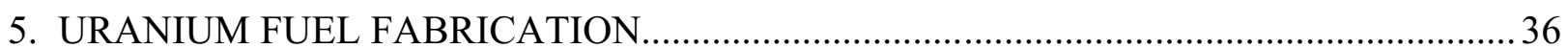

5.1 Brief History and Description of Uranium Fuel

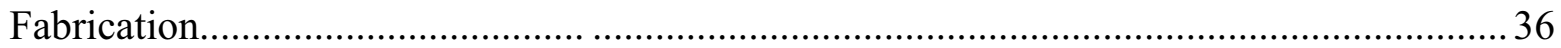

5.2 Summary of Uranium Fuel Fabrication Events of Safety

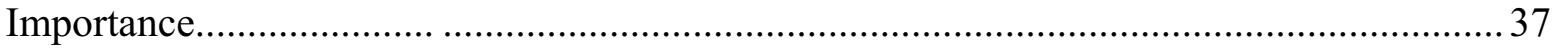

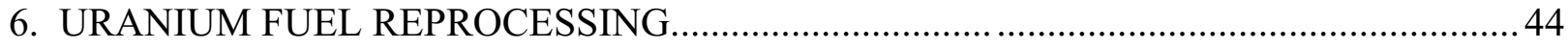

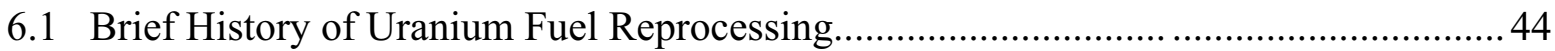


6.2 Summary of Uranium Fuel Reprocessing Events of Safety

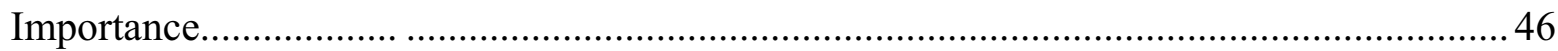

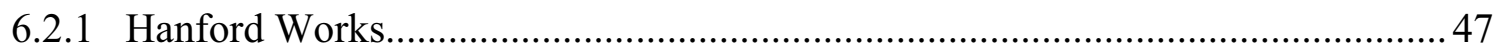

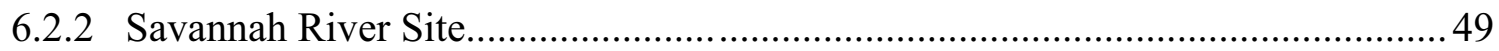

6.2.3 Idaho Chemical Processing Plant.................................................................5 50

TABLE OF CONTENTS

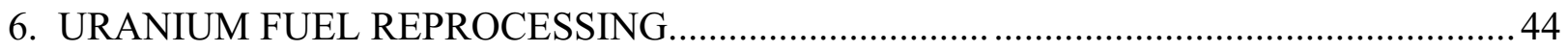

6.2.4 United Nuclear Corporation........................................................................... 51

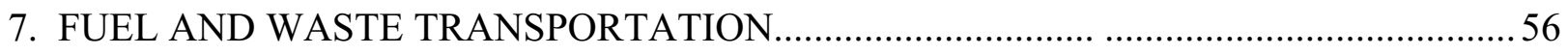

7.1 Brief History of Uranium Fuel and Waste Transportation........................................56

7.2 Summary of Off-Normal Events in Uranium Fuel and

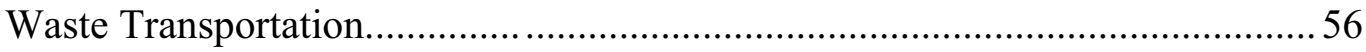

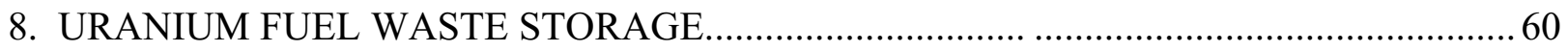

8.1 Brief History and Description of Uranium Fuel

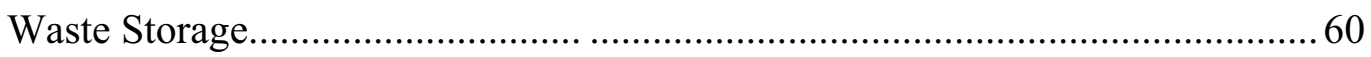

8.2 Summary of Uranium Fuel Waste Storage Events of

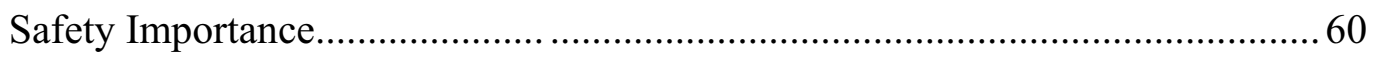

APPENDIX A. Trip Notes from a Visit to a Fuel Fabrication Facility.......................................65

APPENDIX B. Preliminary Quantification of Fuel Cycle Worker

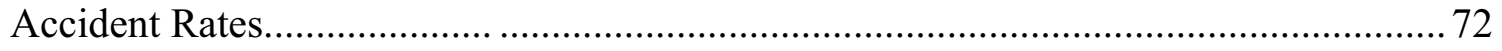

APPENDIX C. Radiation Protection When Handling Minor Actinides for

Nuclear Fuel.................................................................................................... 90

APPENDIX D. Safety and Reliability Issues in the Fabrication of Recycle

Nuclear Fuel 


\section{SUMMARY OF OFF-NORMAL EVENTS IN}

\section{US FUEL CYCLE FACILITIES FOR AFCI APPLICATIONS}

\section{INTRODUCTION}

The Advanced Fuel Cycle Initiative (AFCI) has been initiated by the Department of Energy to examine attractive potential options for new commercial nuclear power fuel cycles. This report originates from the Facility Cycle Safety Assessment task from within the Systems Analysis portion of the AFCI.

The existing US nuclear fuel cycle is the "once-through" cycle of obtaining new uranium from ore, fabricating it into fuel, burning the fuel in a light water reactor, and then storing the spent fuel. The AFCI is to identify several other fuel cycles that are attractive candidates for adoption. There are many criteria to judge in reviewing and comparing various fuel cycle pathways, among them is the safety of the process. There are several levels of safety being considered - the public, fuel cycle workers, co-located workers, and environmental safety.

This report offers an initial step in identifying the past off-normal events and incidents in US fuel cycle operations. This compiled information supports the pathwayto-pathway comparison process. Taking operating experience feedback into account when designing a new facility or choosing a new process is also a best practice in engineering design (Kjellen, 2000). Noting what events have occurred and how these events have affected system and facility designs is important to the AFCI design process; however, the work presented here is an overview nature and more detailed review should be performed to support the detailed design of a new facility. The chapters in this report also contain historical information about the facilities that have operated. The historical information is included for several reasons, including the fact that time periods of operation relate to the technologies available at that facility, the successful operation is counterpoint to reading about accident events, and documentation of facility shut downs can be used when estimating facility deactivation and decommissioning, which has to be performed during the planning of new facilities.

The once-through fuel cycle is defined in Figure 1. The steps consist of mining uranium, conversion of uranium to enrich the percentage of U-235, fabrication of the enriched uranium into fuel assemblies, uranium transport between processing steps and also to a reactor facility, uranium consumption in the power reactor, and then spent fuel storage. While 10CFR20.1003 defines the uranium fuel cycle as milling, conversion, enrichment, fuel fabrication and use in reactors, and reprocessing (not including mining, transportation, disposal site operations or reuse of recovered uranium), here we define the fuel cycle to include all of these related operations. Each of the major steps - mining, conversion, fuel fabrication, transportation, and spent fuel storage - is addressed in this report. 


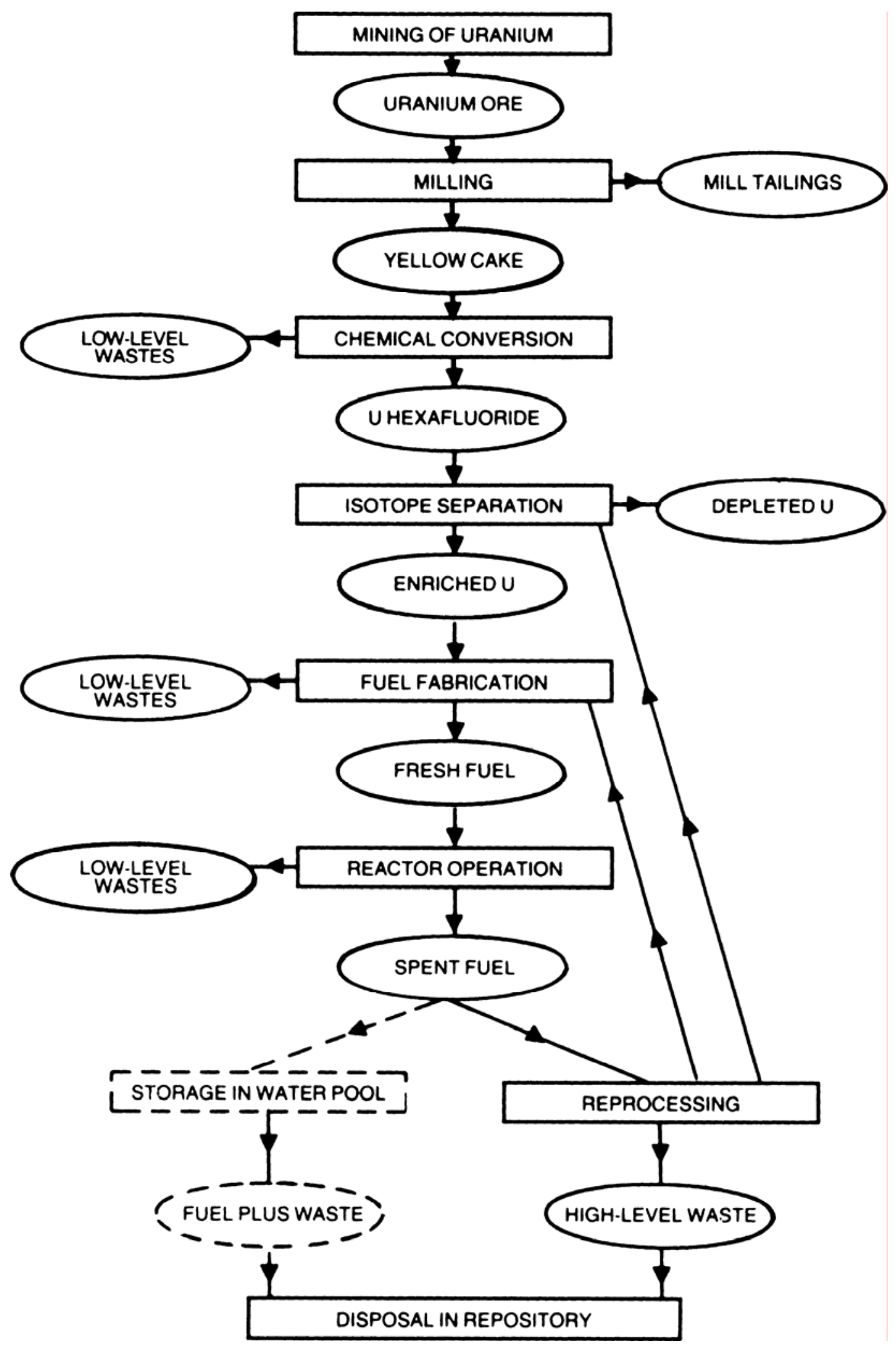

Figure 1. The typical US uranium fuel cycle. (sketch taken from Murray, 1994) 
note: In-Situ Leaching is the only mining process currently in use, thus precluding the need for the traditional uranium milling process 


\section{Chapter 1 References}

Kjellen, 2000. U. Kjellen, Prevention of Accidents through Experience Feedback, Taylor \& Francis, Inc., New York, 2000, chapter 3.

Murray, 1994. R. L. Murray, Understanding Radioactive Waste, fourth edition, Battelle Press, Columbus, Ohio (1994). 


\section{URANIUM MINING AND MILLING}

This chapter describes uranium mining and milling, giving the background and history as well as summarizing safety issues with uranium mines and mills. Mining is the initial event where new uranium is procured. Mining can be underground mining, open pit mining, or in situ leaching (ISL). The type of mining depends on the type of ore that exists and the local geology in the uranium-rich area. Uranium can be found in igneous rock, such as granite, or sedimentary rock, such as sandstone. The chapter is arranged by the steps inherent in this portion of the fuel cycle.

\subsection{Uranium mining}

In the past, beginning in the 1940's, uranium was either mined in underground or open pit mines. Ore that is rich in uranium has also been known to also hold other metals, such as vanadium. Therefore, mills to process the ore to separate out the uranium were needed, and in some cases, separating out the other metals is also beneficial since there is also commercial demand for some of these other metals. Mining and milling developed very rapidly in the 1950's; it has been compared to the gold rush of the 1850 's. Growth was stimulated by the Federal government to assure a reliable domestic supply of uranium for the purpose of weapons production. This purpose was also bolstered by the uranium fuel needs of the developing nuclear power industry in the 1960 's and 1970's. 1980 was the highest production year in the US, with nearly 22,000 tons of natural uranium yellow cake, $\mathrm{U}_{3} \mathrm{O}_{8}$, were produced by twenty-one mills. Demand dropped off as weapons production goals were met and nuclear power fuel needs leveled off. By 1985, only two conventional mills had plans for continued operation (NAS, 1986). Between 1980 and 1993, yellow cake production dropped from 44 million pounds per year to 3 million pounds (EIA, 1995).

2.1.1 Underground mining. Underground mining of uranium in sedimentary ores, primarily sandstone, is performed mainly by the room and pillar method. The room and pillar method is where rooms are cut into the body of ore, leaving large walls of intact ore that act as pillars to support the mine roof and to control the flow of air in the mine. Most coal mining and also much of the salt and limestone mining are done by the room and pillar method; it is the best method for large bodies of ore that are relatively uniform. Veins of ore are mined by the cut and fill method. This method begins with the end of the vein of ore most close to the surface of the ground; the miners tunnel in or down to the vein and as they tunnel deeper into the earth after the vein they fill the upper tunnels with low grade ore and perhaps sand and cement. Thus, the roof of the new, deeper tunnel is composed of the fill material that is stronger and lower density than the initial ore (Wilson, 1996).

Some underground mines would crush ore to the $\sim 300 \mathrm{~mm}$ size on site. Then the crushed ore was trucked to a nearby mill (Wilson, 1996). The mill operates to reduce the size of the ore by crushing and grinding the ore rocks to granule and large powder size so that it can be chemically treated to remove the sought-after metals or metal oxides from 
the other constituent compounds (usually silicon and calcium compounds, and also aluminum compounds and other metal compounds).

2.1.2 Open pit mining. Open pit mining is typically used for materials that are found at depths less than about 200 meters. Generally, explosives are used to break rock into benches of 5 to 20 meters height. Then miners drive progressively into the rock face at the bench. Open pit mining usually has advantages over underground mining, such as higher productivity, higher recovery, and safer working conditions. Often uranium is found in sandstone that is close to the surface; open pit mines were common in the 1950's. However, the environmental impact of open pit mines is greater than in underground mining (Wilson, 1996).

2.1.3 In Situ leaching mining. In situ leaching (ISL) is also called solution mining, and it has two potential advantages over the other, more traditional mining approaches (Wilson, 1996). First, leaching eliminates stripping, mining and milling of the ore, and it does not deposit waste tailings in the mining area. Second, ISL offers the possibility of uranium recovery from lower ore grades than can be economically achieved by the other methods. Solution mining has been used in Texas and Wyoming since the 1970's (Cochran, 1999). In ISL, typically four small wells are drilled at the corners of a $\sim 50$ foot or larger square, and then another small well is drilled at the center of the square. The center well is an injection well for the liquid solution and the corner wells are production wells that recover solution and remove uranium. The liquid solution is typically a mixture of water, oxidants, and an ionic complex agent; it is injected at $\sim 1$ liter/s under a pressure of perhaps 1.5 $\mathrm{MPa}$ to mobilize and dissolve uranium from porous media such as sandstone and then the solution carries the uranium to the surface. ISL eliminates stockpiling, hauling, and blending ore, and it eliminates ore crushing, grinding, and some other milling operations. It also eliminates large-scale excavations (either at ground level or underground), and reduces risk to miners. With ISL, the miners do not work underground or with explosives. Bromley (1987) evaluated mining risks and noted that despite concerns expressed about the hazards of dust, radon exposure, and mine tailings, the dominant form of risk in uranium mining was the mining industrial accidents that resulted in acute fatalities. Anti-nuclear activists assert that miners were never informed of the cancer risks of uranium mining (Eichstaedt, 1994). Bromley noted that, based on industrial accident rates, the ISL was inherently low risk, followed by open pit mining that was lower risk than underground mining. Bromley's values were: 0.17 fatalities per gigawatt-electric/year for underground uranium mining, 0.005 to 0.032 fatalities in open pit uranium mining per gigawatt-electric/year, and 0.012 fatalities per gigawatt-electric/year for ISL. Bromley noted that the mining risk decreased as the ore grade rose. Unfortunately, the ore grade (concentration of uranium in the ore) has declined in the US over the decades (NAS, 1986). Fortunately, the ISL process, that is about 10x less fatality risk than underground mining, can recover uranium from low concentration ores.

The uranium raw material industry in the US is not large; in 2002 employment was only 426 person-years (EIA, 2003). US mine production of uranium is by ISL; there were three commercially operating uranium mines during 2002; the Smith Ranch- 
Highland mine complex in Wyoming, the Highland mine in Wyoming, and the Crow Butte mine in Nebraska. The mines produced a total of 1,150 tons of $\mathrm{U}_{3} \mathrm{O}_{8}$ in 2002 (EIA, 2003).

The Smith Ranch mine (Stover, 1997) uses anionic resin ion-exchange treatment to remove the uranium oxides from the ISL solution. A salt-water solution is added to saturated resin to strip the uranium oxides. Eluted uranium oxide is precipitated, washed to remove impurities, and the resulting yellow cake $\left(\mathrm{U}_{3} \mathrm{O}_{8}\right)$ is dried and packaged in metal drums for truck shipment to an enrichment plant. There are few public risks from ISL and the process is less damaging to the environment than open pit mining. Environmental concerns focus on ground water pollution from ISL; however, the Wyoming Department of Environmental Quality has granted approval to operate such mines (Stover, 1997).

2.1.4 Off-Normal events in mining. The Atomic Energy Commission (AEC) gave some postulated accidents in mines, including floods and washout from heavy rain, fires, loss of ventilation, and loss of control of mine drainage water (AEC, 1972). There were no documents found in the literature search that described actual accidents or incidents with the former uranium mines, and nothing was found in the literature about events involving ISL mining. This finding leaves us with three possibilities: there are no events worthy of reporting, any events that do occur do not reach publication, or the computerized literature searching was not reaching appropriate mining industry publications. From the Mine Safety and Health Administration web page, for 1999-2003, coal mining resulted in an average of 34 fatalities per year, and metal/non-metal mining resulted in an average of 40 fatalities per year. Since uranium mining is a small part of total mining activity in the US, the fatalities in uranium conventional mines should have been commensurately fewer than the coal and metal/non-metal mining industries.

There is; however, literature that documents chronic health problems with uranium miners. Hornung (2001) discussed a study of the health of underground uranium miners. Because of the confined nature of underground mines, this group of miners is at the highest risk for health effects of inhaling radon gas emitted by the uranium ore, and these miners can contract lung cancer from exposure to Radon. Radon222 is a chemically inert gas that is created by U-238 decay. Rn-222 decays into a number of beta- and alpha-emitting radionuclides. Po-214 and Po-218 are radionuclides in this decay chain and are short-lived alpha emitters. These polonium isotopes are thought to be responsible for the alpha particle induced lung damage. Radon is not exclusive to uranium mining, it has been found in other mines, including coal and metal mines (Hewson, 1994). Mining is also a dusty environment, with inhalation exposure to silica, arsenic, chromium and nickel aerosol particles. Underground miners are also exposed to diesel engine fumes and fumes from blasting. Some mines also contain asbestos dust. Underground mining also carries the dangers of poor ventilation, high temperature environment (rock temperatures increase $1{ }^{\circ} \mathrm{C}$ per $100-\mathrm{m}$ depth; there is also exhaust heat from mining machines combined with the heat stress of hard physical labor), large mechanical forces from machines designed to break ore, and other physical hazards 
that include noise and vibration, high humidity due to the use of water to suppress dust, poor lighting, and ergonomic repetitive motion issues (Burgess, 1995).

Based on Bromley's (1987) risk figures, assuming the 100 nuclear power plants in the US are 1,000 MWe and half the mines were underground mines, an average estimate of $\sim 8$ underground miners and $\sim 3$ open pit miners would be killed each year in industrial accidents while keeping US power plants fueled. If all uranium needs were met by ISL, as they are now, then an average estimate of $\sim 1$ miner fatality per year would occur using Bromley's figures. Bromley noted that coal mining risk was in a range of 10 to 30 times higher than uranium mining risk per gigawatt-electric/year.

\subsection{Uranium milling}

The traditional method of obtaining uranium was to mine uranium rich ore and then break up the ore rocks into a powder form and chemically remove the uranium from the other elements in the powder. It is an energy intensive process to haul many tons of ore and to pulverize the ore into powder form. That is one reason for adopting ISL mining. ISL mining can also economically recover uranium from average ore concentrations of $0.1 \%$ yellow cake (Stover, 1997).

2.2.1 Milling process. The initial steps in the milling process included ore weighing, moisture determination, crushing, sampling metal content, blending grades of ore, and grinding (Merritt, 1971). Crushing was accomplished with conventional equipment to reduce the ore size to the 0.75 to 1 -inch size, and ore would be stored in bins where it was stockpiled at the mill and could be blended more easily to achieve a constant uranium concentration as feed input to the mill. Then grinding the ore to the 20 mesh (841 microns) to 200 mesh (74 microns) size was carried out, depending on the ore characteristics and process requirements. Grinding was accomplished by a ball or rod mill (Merritt, 1971). Typically, the ground ore had the consistency of fine sand (NAS, 1986).

After grinding, the ore underwent the uranium extraction phase, where a leach reagent was used to separate the uranium from the rest of the ore. A roasting (furnace heating) step might have been added to increase the solubility of the valued ore minerals during leaching. Most mills used sulfuric acid for an acid leach process; a few mills used sodium carbonate for an alkaline leach process. In either process, the reagent strength, leaching time, oxidation potential and temperature were among the controlled variables (Merritt, 1971). Generally, efficiencies of $90 \%$ uranium collection or better were obtained by the leaching process. The residue from this step is the tailings, which consists of a slurry of sand and fine particles. The tailings include over $90 \%$ of the radionuclide species created by uranium decay and about $99 \%$ of the original ore mass going in to the extraction phase. The tailings also contain varying amounts of the acid or alkaline chemicals, and the toxic elements that were part of the rock that initially contained the ore (NAS, 1986). 
Next, the dilute and impure acid leach solution underwent uranium concentration and purification. There are two major techniques that have been used for this step; these were resin ion exchange and solvent extraction. Usually, ion exchange yielded adequate results, and solvent extraction has been used as a second purification stage following ion exchange. The combined process was referred to as the Eluex process (Merritt, 1971).

Finally, the uranium was recovered from the purified leach solution by chemical precipitation. For the acid leach approach, ammonia, lime, magnesia, or another base was added to precipitate the uranium oxide from the solution. Other metals, such as iron, vanadium, etc., would precipitate out at lower $\mathrm{pH}$ values, so these metals could be extracted for other uses. The uranium precipitate was further purified by roasting, releaching, re-dissolution and re-precipitation, and washing to remove soluble impurities. Then the uranium oxide (yellow cake) was dewatered, dried, and packaged. The yellow cake produced at the mill was an intermediate, semi-refined product.

2.2.2 Off-Normal events in mills. The literature search did not reveal many documents that described actual accidents or incidents in uranium mills in any detail. These facilities were in the private sector and typically did not report any events in the open literature, trade magazine articles, etc. The AEC (1972) briefly described two 1968 solvent fires. The solvent was often kerosene, and it was used in large quantities. At the Petrotomics mill in Wyoming, a kerosene fire was initiated in the solvent extraction system by welding; the fire created $\$ 300 \mathrm{k}$ damages. A similar kerosene fire in an Atlas Company mill caused nearly $\$ 1 \mathrm{M}$ damages, that fire was probably ignited by an electrical arc. In both cases, there was essentially complete recovery of the uranium from the process. Examining soot from the fires showed less than $0.02 \%$ yellow cake, and the readings may have been sensing yellow cake from before the fire occurred (AEC, 1972). There was also mention of a release of 35,000 gallons of tailings to the Colorado River in 1968. Other actual events were smaller fires of industrial origins. Postulated events were given as overflows from process tanks, process line breaches, failure of offgas or scrubbing equipment, and large spills of reagents such as sulfuric acid or kerosene. These types of events were considered to be credible for uranium mills and similar to events occurring in other chemical process industries (AEC, 1972).

The NRC briefly cited two 1980's solvent fires at mills, one event in October 1980 at the Sweetwater mill, and a January 1981 event at the Atlas mill (NRC, 1987). These fires were not consequential events. In 1986, the Plateau Resources, Ltd. mill reported that two employees in the yellow cake packaging area exceeded 40 maximum permissible concentration hours of uranium exposure (NRC, 1987). In 1988, the Atlas Corporation reported it had released Radon-222 to unrestricted areas in excess of $220 \%$ (when averaged over one year) of the maximum permissible concentration permitted by 10CFR20 (NRC, 1989). In 1989, the Sparkling City Nuclear Corporation in Glen Rock, WY, reported a spill of about 7,000 gallons of yellow cake slurry in its processing building. A filter pump that transferred yellow cake to a dryer failed, allowing the slurry to escape (NRC, 1990). After 1989, there was little mention of mills in the NRC 'nonreactor' annual reports. In the early 1990's the last of the conventional mills had shut down in favor of the ISL mines. 
The US Nuclear Regulatory Commission (NRC) issued an information notice about yellow cake (NRC, 1995). The notice described a yellow cake drying process where the granular product was poured onto open trays, heated from the bottom with propane burners, and workers manually mixed and stirred the yellow cake as it dried. The workers were required to wear respirators since the derived air concentration above the trays was about 40 times higher than the 10CFR20 airborne exposure limits for natural uranium. The information was cautionary since the workers could be exposed to amounts greater than the allowable limits.

2.2.3 History of Uranium mills. This section gives brief outlines of the conventional uranium mills that operated in the 1950's and 1960's. The number of mills that were built and operated in a short amount of time give credibility to the statement of very rapid growth of the uranium industry.

The Climax Uranium Company began operations in Grand Junction, Colorado in 1951 with the first mill designed for uranium extraction and vanadium extraction as a byproduct. By 1956 the underground mines were producing 500 tons of ore per day, with typical ore averages of $0.28 \%$ yellow cake and 1.5 to $2.0 \%$ vanadium pentoxide. The average recovery of uranium was $94 \%$ and vanadium was $75 \%$.

The Anaconda Company prospected and also operated an ore buying site for the Atomic Energy Commission at the Bluewater site near Grants, New Mexico in the 1950's. Ore milling commenced in late 1955 and continued for many years. The ore treatment plant could process up to 3,300 tons of ore per day. Mining in the area was mainly open pit mines on the nearby Indian Reservations. The ore typically ranged from 0.25 to $0.60 \%$ yellow cake.

The Atlas Corporation contained a minerals division that operated a mill near Moab, Utah. The mill began operation in 1956. Both the alkaline and acid leach processes were used at the mill, and throughput could reach as high as 1,700 tons of ore per day. Ore was shipped to Moab from 30 various underground mines in the area, some in Utah and some in Colorado. The most famous of those mines was the Mi Vida mine. The ore feeds varied, $0.28 \%$ yellow cake for the alkaline leach circuit and $0.40 \%$ yellow cake for the acid circuit.

The Cotter Corporation built a pilot plant mill at Canon City, Colorado; it was the only uranium ore processing facility on the eastern slope of the Colorado Rocky Mountains. The 75 ton per day pilot plant was expanded to a capacity of 150 to 220 tons per day, and then expanded again to 400 tons per day. The typical ore feed was $0.5 \%$ yellow cake.

The Federal-American Partners Company built a mill near Gas Hills, Wyoming and began operation in 1959. The initial mill capacity was 520 tons of ore per day, it was expanded to handle 950 tons per day. Ore was blended to reach $0.15 \%$ yellow cake concentration. The ore arrived from nearby open pit mines. 
The Foote Mineral Company owned a mill outside of Shiprock, New Mexico. Originally built by Kerr-McGee Oil Industries, Inc., in 1954, the mill was purchased by the Vanadium Corporation of America, which became the Foote Mineral Company. The mill was on the Navajo Indian Reservation, and typically processed 300 tons of ore per day. The mill took ore from as many as 80 small, underground mines in the area, most were very close by, but one mine was 200 miles away. The typical ore concentration was $0.23 \%$ yellow cake and $1.5 \%$ vanadium pentoxide. The Navajo mill produced nearly equal volumes of uranium and vanadium.

The United Nuclear Homestake Partners mill was near Grants, New Mexico. The mill could process over 3,500 tons or ore per day. It was built in 1958 and was fed with ore from underground mines in the Ambrosia Lake and Smith Lake areas near Grants. The ore typically contained $0.21 \%$ yellow cake.

The Kerr-McGee Corporation owned the Grants Uranium Mill, also near Grants, New Mexico. The plant was built in 1958 and it had a rated capacity of 5,000 tons of ore per day. The ore came from underground mines in the Ambrosia Lake area. The ore was handled in 1,000 ton lots. Ore concentration averaged $0.227 \%$ yellow cake, and varied from 0.05 to $0.2 \%$ vanadium pentoxide.

Mines Development, Inc., opened a mill near Edgemont, South Dakota in 1956. The AEC had an ore buying station in Edgemont as well. The mill processed 500 tons of ore per day, and in 1960 installed equipment to also extract vanadium from the ore. The ore concentration was typically $0.20 \%$ yellow cake and $0.25 \%$ vanadium pentoxide. Elemental recoveries were 90 to $95 \%$ uranium and 75 to $80 \%$ vanadium. Some of the ore came from underground mines in the Black Hills of southwestern South Dakota, and some was shipped from Douglas, Wyoming and even from Washington State.

The Petrotomics Company mill was south of Casper, Wyoming. The mill began operation in 1962. It was the most modern, newest mill in the US, being 5 to 10 years younger than other mills. Its capacity reached 1,000 tons of ore per day. The ore was blended to achieve an average $0.20 \%$ yellow cake. Most of the ore came from open pit mines adjacent to the mill.

Susquehanna-Western, Inc., operated a mill near Falls City, Texas (about 50 miles southeast of San Antonio). The mill began operation in 1961, and with upgrades could process up to 1,000 tons of ore per day. The mill was supplied by an open pit mine about 2 miles distant. The ore averaged $0.22 \%$ yellow cake.

The Union Carbide Corporation operated the Uravan mill, in Uravan, Colorado. It was a very old mill, first operated in 1915 by the Standard Chemical Company to recover vanadium and radium, with uranium recovered as well. Union Carbide purchased the mill in 1936 through its subsidiary, the US Vanadium Company and produced uranium and vanadium. The mill could process between 1,000 and 1,200 tons of ore per day. The ore came from underground mines in the Uravan mineral belt, all 
around the mill for a radius of about 35 to 40 miles. The ore concentration was typically $0.20 \%$ yellow cake and $1.0 \%$ vanadium pentoxide.

Union Carbide also operated a mill near Gas Hills, Wyoming. The mill could process up to 1,000 tons of ore per day and began operation in 1960. The ore came from open pit mines nearby. The ore grade ranged from 0.15 to $0.18 \%$ yellow cake.

The Utah Construction and Mining Company began operation in 1958 with the Lucky Mc mine and mill, located in the Gas Hills of Wyoming. The mill was upgraded to handle 1,200 tons of ore per day. Open pit mines were used to collect ore, and the mines were close to the mill. The ore averaged $0.25 \%$ yellow cake.

Western Nuclear, Inc. operated a mill near Split Rock, Wyoming. The mill was built in 1957 and was upgraded to process 1,200 tons of ore per day. Ore came from open pit mines in the Gas Hills region. The average ore grade was $0.25 \%$ yellow cake.

The 15 mills named in this section had an average of $0.256 \%$ yellow cake in their ore at the time Merritt visited the sites. There were also older mines and mills. Before 1962, there were 31 mills built and operated to produce uranium concentrates for the Atomic Energy Commission (Merritt, 1971). Some were small scale 'pilot plant' size. The first was the Grand Junction, Colorado, plant built by the AEC in 1951. It handled 6 tons of ore per day. From 1951 to 1958, the plant produced 69 tons of yellow cake.

The Monticello, Utah mill was also built and operated by the AEC. It was constructed in 1941 and was shut down in 1959. The mill was originally built to obtain vanadium to use in the war effort. Vanadium was used as an alloying element in steel for strength and toughness. In 1949 the mill was rebuilt to collect both uranium and vanadium. Operations at Monticello were terminated on January 1, 1960 and the plant was dismantled.

The Atlas Corporation ran the Mexican Hat mill. The mill was located in southeastern Utah, on the Navajo Indian Reservation. The mill started up in 1957 and it was shut down in 1965. The mill processed up to 1,000 tons of ore per day.

The Dawn Mining Company operated a mill from 1957 to 1965 next to its mine outside of Spokane, Washington. The mill operated at 400 tons of ore per day.

The El Paso Natural Gas Company operated its Tuba City mill, located near Tuba City, Arizona, from 1956-1966. The mill handled slime ores from the Cameron Mining district at 300 tons per day.

After uranium was discovered in 1954 in the Cochetopa mining district southeast of Gunnison, Colorado, a mill was constructed in Gunnison. It was operated by the Gunnison Mining Company. The mill ran from 1958 to 1962, processing 200 tons of ore per day. The mill was shut down and dismantled in late 1962. 
The Homestake-New Mexico Partners built a mill near Grants, New Mexico in 1958. The mill had a feed rate of 750 tons of ore per day. The mill operated until 1962, when it was acquired by another company and some of the equipment was added to the other company's circuit. This mine was plagued with vanadium impurities in its output yellow cake - like many mills using the alkaline leaching process.

The Lakeview Mining Company operated a mill in Lake County, Oregon. The mill was supplied with ore from silicified volcanic rock in the White King ore body, and the mill handled 200 tons of ore per day.

Susquehanna-Western, Inc., built a mill in 1958 near Riverton, Wyoming. The mill operated at 500 tons of ore per day until mid-1963, when it was shut down.

Union Carbide operated a mill near Maybell, Colorado from 1957 to 1964 . The uranium concentration was fairly rich; ore with concentrations of less than $0.20 \%$ yellow cake was considered a lower grade.

Union Carbide also operated a mill near Rifle, Colorado for production of uranium and vanadium. The mill operated for over 45 years, with one element or the other as the leading output. The mill began operation as a US Vanadium Company plant in 1924, and operated until 1932 when ore shortages caused closure. The plant was reactivated during World War II to obtain vanadium. The plant converted to include uranium extraction in 1946. The plant closed in the late 1960's.

In 1963, the United Nuclear Corporation obtained the mill built by the Phillips Petroleum Company in 1958. The mill, near Ambrosia Lake, New Mexico, processed 1,750 tons of ore per day.

The Vanadium Corporation of America (VCA) built a mill near Durango, Colorado in 1941 as part of a Federal Government program to supply vanadium needed for World War II production. Retreatment of vanadium tailings began in 1943 to scavenge uranium to supply the Manhattan Project. The initial capacity of the mill was 175 tons of ore per day, and in 1958 the capacity was expanded to 750 tons per day. The mill was shut down in 1963 and later dismantled. The VCA also bought an idle mill in Naturita, Colorado in 1939. The mill process was altered in 1942 to produce uranium along with the vanadium. The mill processed 150 tons of ore per day.

The Vitro Chemical Company acquired an alumina plant near Salt Lake City, Utah in 1951. The plant was converted to process uranium ore at 100 tons per day. The company halted its uranium processing in 1963 and converted the plant to vanadium production from Idaho ferrophos that came from phosphorous production. The plant was shut down in 1968 and dismantled in 1970.

From this number of mills and the throughput production values, it is easy to understand why the amount of mill tailings was estimated to be over 200 million metric tons (NAS, 1986). Some critics contend that mill tailings are the most serious radioactive 
waste threat since they comprise an extremely large volume of material and contain longlived radionuclides. Proponents argue that the radioactivity is as small or smaller than background radioactivity and the tailings are located in remote mining areas so that the public risk of exposure is very low.

\subsection{Mining and Milling Timeline}

The uranium industry had several perturbations after its rapid growth in the 1950's. First, in the 1960's and 1970's, uranium ore being mined in the traditional method began to decrease its yellow cake concentration, which meant cost increases and increased risks as more ore had to be mined to continue to provide high quality product. ISL was examined as a possible means to mine uranium (Cochran, 1999). Congress enacted the Uranium Mill Tailings Radiation Control Act in 1978 to provide for the disposal, long-term stabilization and control of mill tailings and to minimize or eliminate the health hazards to the public (NAS, 1986). Twenty-four inactive mill sites where uranium was produced for the government weapons program were included for remedial action. In the 1980's, uranium importation became cost competitive with domestic production and nuclear power plant orders were declining, which caused the price of uranium to decrease. More mines and mills shut down when it was no longer economically viable to operate and some of the companies went bankrupt, abandoning the mines, mills, and mill tailings. The tailings issue became a State and Federal government problem by the late 1980's and a portion of 10CFR40 was written in 1985 to address mill tailings. In the 1990's, the tailings problem was studied and efficient methods to deal with the tailings were investigated. Today, most of the mill tailings sites are being remediated; ground water has been cleaned at many sites and final radon barriers have been placed over most of the tailings piles and interim radon barriers over the remaining piles (NRC, 2003). 10CFR40 directs that mill tailings shall be transported to a mill tailings impoundment area for disposal; however, the only uranium mining being performed is by ISL, which is the lowest hazard type of mining and does not produce tailings. The regulation also states that ISL wastes; that is, liquid wastes from the solution extraction process, must be transported to impoundment area or tailings storage sites as well. The NRC has licensed one mill tailings waste disposal facility at South Clive, Utah. The DOE is the steward of this disposal facility. The facility has stored the remediated waste from the Vitro Chemical Company since 1988. The Vitro plant, south of Salt Lake City, was dismantled in 1970. In 1984, the NRC, the State of Utah, and the DOE agreed to move the tailings to South Clive. The 2,798,000 tons of contaminated materials - with a total activity of 1,550 Curies of Ra-226 - were moved by 1988. The Utah disposal facility consists of a 54-acre cell located on a 100 acre plot. The cell is 1,115 feet by 2,110 feet, is 9 feet below grade and rises to 35 feet above grade. the cell is unlined, and has a three-layer cover. The first cover layer is a radon barrier, it is composed of a compacted silty clay that is 7 feet thick. Next is a sand layer, 0.5 foot thick, which protects the radon barrier. Finally, a 2-foot thick rock layer protects the other two layers. The rock "riprap" protects against wind and water erosion, plant root intrusion, and burrowing animals. The layers of the cover are sloped to promote rapid runoff of precipitation to minimize leachate from the tailings. The site has security 
fencing and warning signs. As long as the disposal cell functions as designed, human health risks and environmental risks are negligible (DOE, 2002). 


\section{Chapter 2 References}

AEC, 1972. Environmental Survey of the Nuclear Fuel Cycle, WASH-1237, US Atomic Energy Commission, November 1972.

Bromley, 1987. J. Bromley, "Comparing the hazards of coal and uranium mining," Atom, 365 (March 1987) 3-9.

Burgess, 1995. W. A. Burgess, Recognition of Health Hazards in Industry, A Review of Materials and Processes, 2/e, John Wiley \& Sons, New York, 1995, chapter 26.

Cochran, 1999. R. G. Cochran and N. Tsoulfanidis, The Nuclear Fuel Cycle: Analysis and Management, second edition, American Nuclear Society, La Grange Park, Illinois, 1999.

DOE, 2002. Salt Lake City, Utah, Disposal Site, Long-Term Surveillance and Maintenance Program Fact Sheet, US Department of Energy, Grand Junction Office, Grand Junction, Colorado, March 2002.

EIA, 1995. Decommissioning of US Uranium Production Faculties, DOE/EIA-0592, US Department of Energy, Energy Information Administration, Washington, DC, February 1995.

EIA, 2003. Uranium Industry Annual 2002, DOE/EIA-0478(2002), US Department of Energy, Energy Information Administration, Washington, DC, May 2003.

Eichstaedt, 1994. P. H. Eichstaedt, If You Poison Us: Uranium and Native Americans, Red Crane Books, Santa Fe, New Mexico, 1994.

Hewson, 1994. G. S. Hewson and M. I. Ralph, "An investigation into radiation exposures in underground non-uranium mines in Western Australia," Journal of Radiation Protection, 14 (1994) 359-370.

Hornung, 2001. R. W. Hornung, "Health Effects in Underground Uranium Miners," Occupational Medicine: State of the Art Reviews, 16 (2001) 331-344.

Merritt, 1971. R. C. Merritt, The Extractive Metallurgy of Uranium, Colorado School of Mines Research Institute, Golden Colorado, Library of Congress No. 71-157076, 1971.

NAS, 1986. National Academy of Sciences, $\underline{\text { Scientific Basis for Risk Assessment and }}$ Management of Uranium Mill Tailings, National Academy Press, Washington, DC, 1986. 
NRC, 1987. Report to the US Nuclear Regulatory Commission on Analysis and Evaluation of Operational Data - 1986, NUREG-1272, US Nuclear Regulatory Commission, May 1987.

NRC, 1989. Office for Analysis and Evaluation of Operational Data, 1988 Annual Report - Nonreactors, NUREG-1272, volume 3, number 2, US Nuclear Regulatory Commission, June 1989.

NRC, 1990. Office for Analysis and Evaluation of Operational Data, 1989 Annual Report - Nonreactors, NUREG-1272, volume 5, number 2, US Nuclear Regulatory Commission, July 1990.

NRC, 1995. Handling Uncontained Yellowcake Outside of a Facility Processing Circuit, Information Notice 95-55, US Nuclear Regulatory Commission, December 6, 1995.

NRC, 2003. Uranium Mill Tailings Fact Sheet, US Nuclear Regulatory Commission, Washington, DC, August 2003.

Stover, 1997. D. E. Stover, "Smith Ranch, North America's newest ISL uranium mine," Mining Magazine, October 1997.

Wilson, 1996. P. D. Wilson, The Nuclear Fuel Cycle, from Ore to Waste, Oxford University Press, Oxford, 1996. 


\section{URANIUM CONVERSION}

The previous chapter described mining and milling uranium to produce yellow cake, which is an intermediate product in the process of obtaining uranium for nuclear fuel. This chapter describes the process for converting the yellow cake unenriched uranium $\left(\mathrm{U}_{3} \mathrm{O}_{8}\right)$ into the uranium hexafluoride $\left(\mathrm{UF}_{6}\right)$ feed material for the uranium enrichment process. This $\mathrm{UF}_{6}$ is unenriched, that is, it contains only natural uranium, which is only $0.711 \%$ by weight of the desired U-235 isotope. After the yellow cake is produced at the mill or ISL mine, then it is typically placed in 55 gallon drums and shipped by truck to its destination. After yellow cake purification and conversion to unenriched uranium hexafluoride, the gas is stored in metal cylinders until enrichment proceeds.

\subsection{Brief History and Description of Uranium Conversion}

The yellow cake is a uranium oxide, but despite the efforts at the mill, it is not pure and it is not enriched in U-235. Although the milling or leaching removed or selectively left behind many impurities, such as fission products from spontaneous decay, radium and heavy metals from the earth, etc., the yellow cake must be further purified before it enters the fuel enrichment process. Specifically, any elements such as boron or cadmium that have high neutron capture cross sections must be removed. The elements that could form volatile fluorides later in the refining process, such as molybdenum, vanadium, tungsten, and chromium, must be removed so that they do not contaminate the uranium hexafluoride to be produced at later stages. Other chemically reactive elements, such as chlorine, and their compounds, also require removal. Any metals with properties similar to uranium, such as thorium, must be removed. While some thorium would be removed at the mill, any traces must be removed before enrichment. The yellow cake must be purified to reach "nuclear grade" (Wilson, 1996).

Fortunately, uranium forms coordination compounds easily, meaning the uranium metal atom becomes the central atom of a molecular compound. Such compounds allow the uranium atoms in the molecules to be chemically accessible by organic solvents. The organic solvents are immiscible in water, so aqueous solutions can be used to carry the process chemicals through the process (Cochran, 1999).

Uranium hexafluoride $\left(\mathrm{UF}_{6}\right)$ was chosen as the compound for enrichment since it has several important properties that lend themselves to enriching the uranium. $\mathrm{UF}_{6}$ is a solid at room temperature, which allows easier storage and handling than gases. Above $64 \mathrm{C}$ and $0.15 \mathrm{MPa}, \mathrm{UF}_{6}$ vaporizes. The fluorine atoms have only one stable nuclide and are low atomic weight, 19, compared to uranium 238, so forming 6 fluorine atoms with uranium gives less than $50 \%$ additional weight to the molecule; the 6 fluorine atoms are always atomic weight 19 and they do not dwarf the mass difference between U-235 and U-238. Keeping the total molecular mass low allows the U-235 hexafluoride to be separated from the U-238 hexafluoride by either gaseous diffusion or by gas centrifuge operation. 
There are two approaches to purifying the yellow cake before converting it to uranium hexafluoride. These are both solvent extraction processes. The first is the uranium extraction (UREX) process, where uranyl nitrate, $\mathrm{UO}_{2}\left(\mathrm{NO}_{3}\right)_{2}-6 \mathrm{H}_{2} \mathrm{O}$, is extracted selectively from aqueous solutions by oxygenated solvents, such as diethyl ether, methyl isobutyl ketone, and tributyl phosphate (TBP) (Benedict, 1957; Harrington, 1959; Cochran, 1999). At the Feed Materials Production Center (FMPC) at Fernald, Ohio, the TBP process was used to purify uranium. The yellow cake was dissolved in aqueous nitric acid and then the uranyl nitrate was extracted from the solution using TBP in kerosene, forming a complex molecule, $\mathrm{UO}_{2}\left(\mathrm{NO}_{3}\right)_{2} \cdot 2 \mathrm{TBP}$, which is soluble in kerosene and was extracted by the kerosene. With the uranyl nitrate selectively separated from the impure yellow cake, it would be back-extracted into a large volume of water. The purified uranyl nitrate would be concentrated by evaporating the water and then calcined (heated) to produce $\mathrm{UO}_{3}$, sometimes called "orange oxide" (Benedict, 1957). The uranium trioxide was another intermediate product. The $\mathrm{UO}_{3}$ was then fed through a set of furnaces or chemical reactors. The first furnace reduced the $\mathrm{UO}_{3}$ to $\mathrm{UO}_{2}$. Heated hydrogen was flowed over the uranium oxide to form some water vapor, leaving $\mathrm{UO}_{2}$; the furnaces or chemical reactors each had an internal screw to churn the material for increased contact with the counter-flowing gas. The hydrogen reactors operated at $\sim 650$ ${ }^{\circ} \mathrm{C}$. The plant produced the quantities of hydrogen needed by cracking ammonia. Next, the $\mathrm{UO}_{2}$ was moved to another furnace or chemical reactor for hydrofluorination at 650 ${ }^{\circ} \mathrm{C}$, that is, the oxide was converted to $\mathrm{UF}_{4}$ by flowing hydrogen fluoride over the uranium compound. Water vapor and HF gas would leave the furnace. The uranium tetrafluoride has been called "green salt". The uranium tetrafluoride product can be converted into uranium hexafluoride or into uranium metal. The Fernald plant also would produce uranium metal from $\mathrm{UF}_{4}$; the uranium metal was used as targets in fission reactors to produce plutonium by neutron absorption in $\mathrm{U}-238$.

To convert to hexafluoride, the uranium tetrafluoride was reacted with fluorine gas in a furnace at $250{ }^{\circ} \mathrm{C}$, thus creating $\mathrm{UF}_{6}$ gas. The fluorine feed material at FMPC was produced by electrolysis of HF gas (Benedict, 1957). The hot UF 6 gas leaving the furnace was cooled and condensed, then the liquid was poured into large cylindrical tanks and allowed to solidify at room temperature, typically requiring $\sim 5$ days at $20 \mathrm{C}$ atmospheric temperature to equilibrate. The tanks were shipped to an enrichment center for storage until the product could enter the enrichment process.

The processes described here were all chemical separations processes to purify uranium and prepare the purified, natural uranium for enrichment in the isotope U-235. Obviously, there are a number of hazards, including high temperature processes, acids, flammable solvents, toxic gases, pyrophoric compounds, and potential exposure to uranium powder.

Uranium conversion plants that prepare uranium to make power plant nuclear fuel in the US include the Sequoyah Fuels plant in Gore, Oklahoma (now shut down), and the former Allied Signal conversion plant in Metropolis, Illinois. The Metropolis plant is now owned by Honeywell International, Inc., and is the only operating facility in the US 
at this time; the plant has a capacity of 12,700 tons Uranium/year (IAEA, 2001; NRC, 2005).

\subsection{Summary of Uranium Conversion Events of Safety Importance}

The AEC (1972) described a few events that had occurred in conversion plants. The Kerr-McGee plant in Oklahoma suffered a valve bonnet failure in the line from a vaporizer tank in the distillation portion of the plant (this plant later was renamed as the Sequoyah Fuels plant). This plant converted yellow cake to $\mathrm{UF}_{6}$ by using the dry hydrofluor process, hence the vaporizer tank. The release was about 90 to 95 pounds of uranium as $\mathrm{UF}_{6}$ gas into a basement room of the plant. The workers acted to freeze the vaporizer tank to stop the leak, and they used a vacuum to retrieve the effluent gas. During repairs, two employees were exposed to hydrogen fluoride and uranyl fluoride $\left(\mathrm{UO}_{2} \mathrm{~F}_{2}\right)$ gases, but no gas escaped the building. Another event occurred at the Allied Chemical plant when an operator spilled yellow cake. While introducing yellow cake into the head end of the $\mathrm{UF}_{6}$ production process, the operator was attempting to empty a non-standard short drum of yellow cake concentrate with a mechanical drum dumper. He accidentally spilled about 250 pounds of yellow cake, which required cleanup on three floors of the process building. No yellow cake was released to the environment (AEC, 972). Other events that were briefly mentioned were valve and piping failures, gland leaks, joint breaks, loss of services or utilities, and other small spills. These types of events were classed as typical industrial accidents that had low potential for off-site effects. These events are also typical of the chemical process industry. The large quantities of nitric and hydrofluoric acid stored at these facilities means there is some likelihood of a leak or spill; however, the typical industrial precautions of dikes, berms, and crushed limestone for neutralization mitigate any releases. Other possible events are: solvent fire, release of hot $\mathrm{UF}_{6}$ gas, waste retention pond dike rupture, and uranyl nitrate (UNH) evaporator breach (AEC, 1972).

The US Nuclear Regulatory Commission (NRC) issued an information notice about yellow cake storage (NRC, 1999). The notice reported that yellow cake in 55gallon drums had undergone strong exothermic reactions. For yellow cake that was hydrogen peroxide precipitated at a mill, either excess oxygen was given off or hydrocarbon contamination (e.g., such as lubricating oil or grease from conveyors or auger machines) of the yellow cake caused heat that pressurized the drums. Any hydrogen peroxide left after processing the yellow cake had decomposed and the oxygen and hydrogen gas overpressurized the drums, bulging the sides and the lids. When lubricating oil leaked into the yellow cake and was packaged into a drum, energetic reactions occurred. In one drum, the lid melted to the rim in one spot, and in another drum the reaction reached $648^{\circ} \mathrm{C}\left(1,200{ }^{\circ} \mathrm{F}\right)$. The NRC stated that yellow cake is one of the more benign substances in the fuel process, but it is by no means a harmless chemical. Yellow cake will continue to oxidize when heated, and it also has occupational inhalation exposure limits. This information is presented in the conversion section since the yellow cake most often resides at the conversion center rather than at the mill. 
The experiences of uranium conversion centers in the US include plants now decommissioned and the single operational plant. The Feed Materials Production Center (FMPC) is decommissioned, but its experiences are relevant to future plant design. The FMPC is located about 20 miles northwest of Cincinnati, Ohio, near the town of Fernald. The FMPC is also referred to as the Fernald plant. The FMPC could use up to $375 \mathrm{MW}$ of electricity to operate and process over 1,000 tons of yellow cake per month (NLCO, 1965). The plant began full-scale operation in January 1954, but is no longer operational and it is currently undergoing decommissioning and environmental cleanup; according to the web site fernald.gov, as of June 2005 the cleanup of all 255 buildings in the FMPC complex was $80 \%$ complete. Other plants include the Mallinckrodt Chemical Works at Weldon Spring, Missouri (Harrington, 1959), and the Sequoyah Fuels Corporation (SFC) facility near Gore, Oklahoma (IAEA, 2001). The Mallinckrodt facility operated from 1942 to 1966, employing 3,300 personnel and produced over 100,000 tons of purified natural uranium materials (Goldsmith, 1981). No reports about events at the Mallinckrodt facility were found in the literature search. One worker health study was found that indicated the average exposure for radiation workers at Mallinckrodt was 9.2 $\mathrm{mSv} / \mathrm{year}$, and the cohort of former workers exhibited the 'healthy worker' effect (Dupree-Ellis, 2000). There has been public concern about environmental pollution of waterways near the facility. The FMPC, SFC, and Honeywell plant experiences are discussed below.

3.2.1 Feed Materials Production Center. The FMPC site had several safety issues, among them were the atmospheric releases (Boback, 1987; Clark, 1989) and losses of product. An example of a release is an event on February 14, 1966. A UF 6 release of 3,844 pounds occurred when an operator inadvertently unscrewed the valve from a 10ton cylinder during routine startup operations. One employee received inhalation exposure and was hospitalized for six days. Other exposed workers were treated at the dispensary. Product loss was estimated at $\$ 278 \mathrm{k}$ and cleanup costs were $\$ 21 \mathrm{k}$ (AEC, 1975).

A uranium trioxide spill at the FMPC was documented in an accident investigation report (DOE, 1986). On November 11, 1986, about 230 pounds of uranium trioxide powder was spilled from the chemical processing system that converted oxide to fluoride. The powder was slightly enriched, at $1.25 \% \mathrm{U}-235$. The incoming $\mathrm{UO}_{3}$ powder was moved by screw augers and fed via a hopper and valves into a fluid bed reactor, where the powder would be exposed to hydrogen to begin the conversion of uranium trioxide to dioxide. Then the mixture would be moved to a heated chemical reactor with an internal screw. In the chemical reactor the reaction would be completed. The spilled powder remained in the radiological control area. The spill occurred because of an opening that was created between the $\mathrm{UO}_{3}$ hopper and the feeder line to the fluid bed reactor. Miscommunication allowed the hopper to be overfilled, and component wear, combined with less than adequate maintenance, led to the creation of a breach in the system. The operator noticed dust emanating from the hopper and shut down the system. Within two minutes of his action, the supervisor shut down both fluid bed reactors. Temporary barriers were erected to identify the affected area. Bioassay samples from 
personnel involved in the operation in the building all showed uranium concentrations below the administrative notification level of 15 micro-grams U/liter. Worker exposures were at $1 \%$ of the DOE radiation standards.

The National Institute for Occupational Safety and Health (NIOSH) visited the FMPC twice in the 1980's in response to requests from workers. In the first site visit, the NIOSH team investigation focused on the extent of uranium exposure and potential health effects on workers after releases of uranium during November and December 1984. The Department of Energy Mobile Van for in vivo monitoring of workers gave data results that showed that if there was any contamination of workers, it was below the maximum permissible lung burdens permitted by the DOE and therefore no adverse health effects would be expected (NIOSH, 1987). The team did recommend that the Mobile Van should have an independent check of its monitoring system, particularly by installing a permanent system for in vivo monitoring at the FMPC. The second report described NIOSH measurements made with alpha particle-detecting radiation survey meters and air sample collectors, which identify radioactivity and chemicals present in air. Chemicals that were assessed included particulate and gaseous fluorides, nitric acid, nitrogen dioxide, hydrofluoric acid, ammonia, graphite dust, and oil mist. The contractor verified the calibration of the radiation survey meters and also collected many "side-byside" samples of air in the facilities that NIOSH visited. The results were that there was some chemical exposure in the air, slight amounts of fluorides, hydrogen fluoride, and ammonia, but the concentrations of these chemicals were well below the threshold limit values of the time period. NIOSH recommended forming better communications between safety personnel, plant workers, and management.

The FMPC has been estimated to have released 179,000 kilograms of uranium and 6,500 kilograms of thorium into the air between 1951 and 1987 (Clark, 1989). While this is a large amount, it is only a small fraction of the total production. Consider that at $\sim 1,000$ tons of yellow cake per month, with yellow cake being $85 \%$ uranium, and using $\sim 30$ years of production, the result is that the FMPC processed over $2.5 \times 10^{8} \mathrm{~kg}$ of uranium. The ratio of total uranium lost to the total production flow is then $0.065 \%$. The total releases are large at 179 metric tons, but the scale of uranium that the facility handled was much larger at 250,000 metric tons. The largest airborne releases were early in the life of the facility (Clark, 1989). As part of the Fernald Living History project, an interview with Mr. Bernard Gessiness, an analytical chemist and materials accountancy manager at FMPC from 1952-1987, indicated that there was a 'production quota' mentality at the facility, where the production supervisors were always striving to produce high amounts of final uranium product. This is a well-known attitude among operations personnel, and in the FMPC case there was also the issue that their output was not only unique but also a crucial constituent for national defense. Mr. Gessiness stated that periodic cleanup sessions in FMPC buildings were viewed as detracting from production goals. He mentioned that sometimes the filter bags in the bag houses would break and send airborne dust up the building stacks, and surges in the processes would release airborne material. He noted that sometimes the staff could see orange oxide or green salt on the building roofs and the staff would clean the roof and try to estimate the mass released (FLHP, 2000). If a new facility should operate with lower emissions than 
FMPC, then the advantages of new technology and successive levels of confinement must be used. At FMPC, releases of powder from the process equipment were direct to the plant room, then room ventilation filtered the air and powder, and then the effluent was vented to the atmosphere. A new design might use secondary confinement barriers around the production lines, or local exhaust ventilation with extra filtration stages, to reduce off site releases.

3.2.2 Sequoyah Fuels Corporation. Another conversion facility was operated by the Sequoyah Fuels Corporation, (SFC) located near Gore, Oklahoma (NRC, 1986). This facility is also shut down (IAEA, 2001). At the SFC facility, dry yellow cake was stored in 55-gallon drums, the drums were tied to pallets for protection from toppling. The yellow cake would be poured from 55-gallon drums into feed hoppers that used screwtype feeders to route the powder into 4,000-gallon nitric acid digestion tanks. There the yellow cake would be converted into uranyl nitrate solution. The tanks used in-tank steam coils to heat the nitric acid to between 88 and $104 \mathrm{C}$. The yellow cake to uranyl nitrate reaction is exothermic, so water-cooling coils were also used on the tank walls to control the solution temperature. Nitrogen oxides would be evolved in this step. Then the liquid would be pumped to solvent extraction systems to purify the uranium. The SFC used the tributyl phosphate in hexane solvent as the process for separating and purifying the uranium. The SFC used a countercurrent extraction with a series of pumper-decanters. The organic extraction product contained most of the uranium, there was little in the raffinate waste stream. The raffinate was left in settling basins for treatment and disposal. The organic extraction product was rinsed with nitric acid and then the uranium would be stripped from the organic into an aqueous phase. Aqueous uranyl nitrate 'liquor' would be evaporated and recondensed. The concentrated product, uranyl nitrate hexahydrate would be heated in a denitrator at $\sim 288 \mathrm{C}$ to obtain $\mathrm{UO}_{3}$, nitrogen oxides, and water vapor. Like the FMPC, ammonia would be cracked to provide hydrogen. The hydrogen would be combined with the uranium trioxide in a fluid bed reactor to reduce it to uranium dioxide and water vapor. The reactor would operate in the 510 to $590 \mathrm{C}$ temperature range.

The US NRC reported an event of a uranium hexafluoride cylinder rupture and release on January 4, 1986 (NRC, 1986; NRC, 1987). This event was much more consequential than those of many years of fuel plant operations. A cylinder overfill also occurred at SFC on March 13, 1986, but there was no release in the second event (NRC, 1986a). The US NRC reported two employee exposure events in 1987 . Due to equipment failures of a fill line and a dust collector, two employees received 2.26 and 9.82 maximum permissible concentration-days of uranium exposure. One event occurred in February and the other event was in March 1987 (NRC, 1988). In 1989, SFC workers were performing maintenance on a vaporizer. The bleed valve to a second vaporizer was inadvertently left open and residual heating allowed HF gas to form, which passed through the bleed valve to the vaporizer under maintenance. A small amount of HF gas was released to the air, but there were no injuries (NRC, 1990). Searching the Nuclear Material Events Database (NMED) that is operated by the US Nuclear Regulatory Commission, there were over 50 events that have occurred at the SFC in over the 19901993 time span. These events were mainly small releases of uranium compound powders 
and vapors from process equipment. The typical types of events were valve failures, valve seal leaks, flange leaks, cracks in piping, and bellows failure. A few other events involved a broken automatic sprinkler pipe and the fire water leakage washed uranium contamination from the machines into process rooms. In other events, workers opened an access port on a powder conveyor and powder leaked out, and when trying to clear a plugged line some solidified uranium hexafluoride combined with air and formed a cloud. Most releases were gram scale, only a few were kilogram scale. The SFC shut down in the mid-1990's.

3.2.3 Honeywell International. The Metropolis, Illinois uranium conversion plant was operated by Allied Signal, Inc. for many years, and then it was acquired by Honeywell International, Inc., in 2000. The site accepts yellow cake from mines and produces uranium hexafluoride for enrichment. The NRC reported a few events of concern in 1987. One event was a small hexafluoride release when a cylinder was sampled. Another event was a near miss during cylinder handling. A liquid-filled cylinder was being towed and the driver crossed a rail track while a tank car of HF was being moved on the track. He did not see nor hear the moving tank car and engine, the engine stopped within three feet of the cylinder. In another event, a drum was accidentally overturned in the plant, spilling 300 pounds of yellow cake (NRC, 1988). Scanning the NMED data on this facility has given a few events of safety importance from 1990 to 2004. The largest leak was about $3.2 \mathrm{~kg}$ of uranium hexafluoride gas in December 2003. The gas release cloud propagated off site and a limited public evacuation was required for safety; this event is discussed in more detail in chapter 5. Other events have involved releases in the less than $1 \mathrm{~kg}$ range, usually the gram range. Those events involved heat exchanger tube failures, operators dislodging a plug of solidified $\mathrm{UF}_{6}$ in a sampling line (which resulted in a small gas release), valve and valve gasket failures, and a few human errors in system operation and valve alignment. Some power losses led to small releases when dust collector vacuum was lost; there were also reports of the emergency diesel generators not operating when tested. There were no fires reported, and no personnel exposures above recommended limits in the NMED. Events of valve stem leaks, flange leaks, pipe cracks, etc., are endemic in the chemical process industry (Kletz, 1988; Kletz, 1998; Sanders, 1999; Kletz, 2003; King, 1998) and also occur in these predominately chemical processes (AEC, 1972).

The chemical processes described in this chapter - including furnace heating, acid reactions, and bulk material handling - and the operating experience evidence from the NRC and the NRC NMED indicates that the fuel purification and conversion process is based in the chemical industry rather than the nuclear power industry even though nuclear material is being handled. Due to the lack of criticality concerns, the uranium materials, processes, and operating experience described in this chapter are more closely aligned with traditional chemical industry processing than the nuclear power industry. The purification and conversion plants are designed and operate more like chemical process industry plants than power plants or other nuclear facilities. This is not surprising since these processes and some of the plants were born from chemical companies for the wartime need of producing uranium and plutonium for the war effort. As is more typical of the chemical process industry, a single failure of a pipe, tank, or 
valve allows a release to the room or to the air, and the rooms use ventilation control with filtration rather than the containment buildings used in nuclear power plants, which followed $\sim 10$ years after some of these facilities. The construction is commensurate with the hazard. 


\section{Chapter 3 References}

AEC, 1972. Environmental Survey of the Nuclear Fuel Cycle, WASH-1237, Atomic Energy Commission, November 1972.

AEC, 1975. Operational Accidents and Radiation Exposure Experience within the United States Atomic Energy Commission, 1943-1975, WASH-1192, US Atomic Energy Commission, Fall 1975.

Benedict, 1957. M. Benedict and T. H. Pigford, Nuclear Chemical Engineering, McGraw-Hill Book Company, New York, 1957.

Boback, 1987. M. W. Boback et al., History of FMPC Radionuclide Discharges, FMPC2082, Westinghouse Materials Company of Ohio, May 1987.

Clark, 1989. T. R. Clark, History of FMPC Radionuclide Discharges: revised estimates of uranium and thorium air emissions from 1951-1987, FMPC-2082-addendum, Westinghouse Materials Company of Ohio, March 1989.

Cochran, 1999. R. G. Cochran and N. Tsoulfanidis, The Nuclear Fuel Cycle: Analysis and Management, second edition, American Nuclear Society, La Grange Park, Illinois, 1999.

DOE, 1986. Investigation of Uranium Trioxide Spill at the Feed Materials Production Center, Plant Four, DOE/ORO-878, US Department of Energy, November 11, 1986.

Dupree-Ellis, 2000. E. Dupree-Ellis, J. Watkins, J. N. Ingle, and J. Phillips, "External Radiation Exposure and Mortality in a Cohort of Uranium Processing Workers," American Journal of Epidemiology, 152 (2000) 91-95.

FLHP, 2000. Fernald Living History Project, interview with Bernard Gessiness, performed on February 23, 2000, FER/FLHP/TRANS/FLHP-103, interview number 103, available at the fernald.gov web site.

Goldsmith, 1981. W. A. Goldsmith et al., Radiological Survey of the Mallinckrodt Chemical Works, St. Louis, Missouri, DOE/EV-0005/27, ORNL-5715, Oak Ridge National Laboratory, December 1981.

Harrington, 1959. C. D. Harrington and A. E. Ruehle, Uranium Production Technology, Van Nostrand Company, Princeton, New Jersey, 1959, chapter 4.

IAEA, 2001. Country Nuclear Fuel Cycle Profiles, Technical Reports Series No. 404, International Atomic Energy Agency, Vienna, Austria, 2001. 
King, 1998. R. King and R. Hurst, Safety in the Process Industries, second edition, Elsevier Publishers, Amsterdam, 1998.

Kletz, 1988. T. A. Kletz, Learning from Accidents in Industry, Butterworths, London, 1988.

Kletz, 1998. T. A. Kletz, What Went Wrong? Case Studies of Process Plant Disasters, Gulf Publishing Company, Houston, Texas, 1998.

Kletz, 2003. T. A. Kletz, Still Going Wrong: Case Histories of Process Plant Disasters and How They Could Gave Been Avoided, Elsevier Publishers, New York, 2003.

NIOSH, 1987. Health Hazard Evaluation Report HETA 85-111-1770, Feed Materials Production Center, Fernald, Ohio, accession number PB87-206587, National Institute for Occupational Health and Safety, Cincinnati, Ohio, January 1987.

NIOSH, 1989. Health Hazard Evaluation Report HETA 83-144-2001, Feed Materials Production Center (Westinghouse Materials Company of Ohio), Fernald, Ohio, accession number PB91-108183, National Institute for Occupational Health and Safety, Cincinnati, Ohio, December 1989.

NLCO, 1965. National Lead Company of Ohio, contract operator for the Feed Materials Production Center, NLCO-950, NLCO, Cincinnati, Ohio, March 1965.

NRC, 1986. Assessment of the Public Health Impact from the Accidental Release of UF 6 at the Sequoyah Fuels Corporation Facility at Gore, Oklahoma, NUREG-1189, US Nuclear Regulatory Commission, March 1986.

NRC, 1986. Rupture of Model 48Y UF-6 Cylinder and Release of Uranium Hexafluoride, Sequoyah Fuels Facility, Gore, Oklahoma, January 4, 1986, NUREG-1179, volume 1, US Nuclear Regulatory Commission, February 1986.

NRC, 1986a. Rupture of Model 48Y UF-6 Cylinder and Release of Uranium Hexafluoride, Cylinder Overfill, March 12-13, 1986, Investigation of a Failed UF-6 Shipping Container, NUREG-1179, volume 2, US Nuclear Regulatory Commission, June 1986.

NRC, 1988. Report to the U.S. Nuclear Regulatory Commission on Analysis and Evaluation of Operational Data - 1987, Nonreactors, NUREG-1272, volume 2, number 2, US Nuclear Regulatory Commission, October 1988.

NRC, 1990. Analysis and Evaluation of Operational Data, 1989 Annual Report Nonreactors, NUREG-1272, volume 4, number 2, US Nuclear Regulatory Commission, July 1990. 
NRC, 1999. Exothermic Reactions Involving Dried Uranium Oxide Powder (Yellowcake), Information Notice 99-03, US Nuclear Regulatory Commission, January 29, 1999.

NRC, 2005. Information Digest, 2004-2005 edition, NUREG-1350, volume 16, revision 1, US Nuclear Regulatory Commission, February 2005.

Sanders, 1999. R. E. Sanders, Chemical Process Safety: Learning from Case Histories, second edition, Elsevier Publishers, New York, 1999.

Wilson, 1996. P. D. Wilson, The Nuclear Fuel Cycle, from Ore to Wastes, Oxford University Press, Oxford, UK (1996) chapter 3. 


\section{URANIUM ENRICHMENT}

The previous chapter described conversion of yellow cake into uranium hexafluoride gas, which is the compound of choice for enriching the natural uranium to higher levels of U-235. The uranium hexafluoride is stored in gas cylinders, some of which can be quite large, and is transported by truck or rail to the enrichment plant. There the $\mathrm{UF}_{6}$ is enriched to the desired concentration of $\mathrm{U}-235$ and the $\mathrm{UF}_{6}$ compound is retained as enriched $\mathrm{UF}_{6}$. Depleted $\mathrm{UF}_{6}$ is also retained in the case that depleted uranium can be used for other purposes. As the uranium is enriched, nuclear criticality concerns appear. Up to this point in the fuel manufacturing process, the uranium was only natural and had no criticality concerns unless excellent neutron moderation was provided.

\subsection{Brief History and Description of Uranium Enrichment}

When the wartime need of uranium for weapons was understood, some choices had to be made regarding the means to obtain large quantities of the rare U-235 isotope. Two approaches were adopted, electromagnetic separation and gaseous diffusion. In electromagnetic separation, the $\mathrm{UF}_{6}$ was ionized, and the slightly heavier U-238 hexafluoride molecule did not migrate to a charged plate as quickly as the lighter U-235 hexafluoride. Therefore, the gas molecules were separated. The Y-12 plant at Oak Ridge National Laboratory operated the electromagnetic separation process during World War II. The other means was gaseous diffusion, where the $\mathrm{UF}_{6}$ was passed through membranes with very small openings or passages, so that the lighter U-235 hexafluoride could negotiate the membrane slightly faster than the heavier molecules. By routing the gas through many sets (i.e., thousands) of membranes in series, the gas was separated. The electromagnetic separation was quite energy intensive for the efficiencies realized, and gaseous diffusion was the chosen as the main approach for enrichment (LLNL, 1995). However, gaseous diffusion is also very energy intensive.

The Oak Ridge Gaseous Diffusion Plant near Oak Ridge, Tennessee, began construction in 1944 to support the wartime need for uranium; its first shipment of enriched uranium was made in March 1945. The plant additions were completed in 1954. The plant was quite large, with 210 acres of building floor area; there were five very large process buildings and about 70 auxiliary buildings. At full power, the plant drew 2,100 MW of electricity. There were 5,100 enriching membrane stages in the facility, which could enrich up to $93.15 \%$ U-235. In June 1985, the US DOE made the decision to place the plant in standby mode since there was a decreased need for enriched uranium in both the nuclear power industry and in the national defense effort. In December 1987, the DOE reached a decision to shut down the plant permanently (LLNL, 1995).

The Paducah gaseous diffusion plant, outside of Paducah, Kentucky, was constructed between 1951 and 1954. The process building area was 150 acres. This plant used 3,040 MW of electricity and had 1,800 enriching stages. The Paducah plant could only enrich up to $2 \% \mathrm{U}-235$. The original intent for this plant was to help meet the increased enrichment demands that had been placed on the Oak Ridge plant. Paducah 
was meant to operate in conjunction with Oak Ridge; all enriched uranium from Paducah was to be sent to Oak Ridge for further enrichment. The Paducah plant capacity was later increased to produce up to $5 \%$ enriched uranium, which could meet commercial needs (LLNL, 1995).

The Portsmouth gaseous plant, near Piketon, Ohio, was constructed between 1953 and 1956. The process building area itself was 200 acres. The Portsmouth plant originally was built with 4,000 enrichment stages and could enrich up to $97.65 \%$ uranium-235. That enriched uranium was used for the Naval Reactors program. After the high enrichment production equipment was placed on standby, the plant then used 2,150 MW of electricity and only 2,820 enriching membrane stages. The maximum enrichment possible was 10\% U-235 (LLNL, 1995). In May 2001, the United States Enrichment Corporation (USEC) terminated enrichment operations at Portsmouth. Therefore, the only operating gaseous diffusion plant in the US is at Paducah, Kentucky.

On October 24, 1992, the President signed the "Energy Policy Act of 1992", which established a new corporation, the United States Enrichment Corporation, to manage and operate the uranium enrichment plants owned and operated by the US DOE. The two plants were the Portsmouth and Paducah plants, and final transfer of regulatory authority over diffusion plant operations occurred on March 3, 1997 (NRC, 1998).

The US DOE also began some small scale testing of gaseous centrifuge enrichment processes at Portsmouth (from the usec.com web site). The centrifuge concept also uses the mass difference between U-235 hexafluoride and U-238 hexafluoride. The hexafluoride gas is sent to an evacuated cylindrical drum. By imparting rotational motion to the centrifuge drum, the heavier gas moves to the outer circumference of the drum, and the lighter gas molecules are then drawn off from the axis of the drum. Many tall, slender centrifuge drums are needed for efficient separation, similar in principle to the cascade of membrane stages in a diffusion plant. Centrifuges also refer to a cascade, which is a row of centrifuge drums that are interconnected in series. Centrifuge enrichment is the favored approach in Europe (Wilson, 1996), since it is much less energy intensive than diffusion; instead of compressing and driving gas through successive stages of membranes, the centrifuges are mechanically rotated at high revolutions per minute. Centrifuges use on the order of $\sim 4 \%$ of the energy that diffusion plants use. The US planned for construction of a centrifuge plant in the 1970's and 1980's (Arthur, 1980) and early 1990's (NRC, 1994; NRC, 1994a) but neither were constructed. Reasons for the initial building construction at Portsmouth with subsequent cancellation in the 1980's are not clear. The 1990's plans were challenged when laser isotope separation techniques looked technically promising. A newer centrifuge plant design is currently under development by the USEC, considering a site in New Mexico. The US NRC gave license approval for construction and operation of an advanced gas centrifuge enrichment facility in February 2004 (from the usec.com web site).

The Paducah plant receives the large cylinders (e.g., 10 and 14 ton cylinders) of uranium hexafluoride from a conversion center, such as the Honeywell plant in Illinois. The cylinders are stored in cradles inside a fenced plot of ground; they are moved by 
straddle carrier to the plant as needed. A cylinder placed in an autoclave type of oven and is plumbed to plant piping through a 'pig tail' hose assembly. Then the cylinder is heated to at least $67 \mathrm{C}$ to change the solid phase $\mathrm{UF}_{6}$ to gaseous form. Steam heat is used in the autoclave, which is basically a much larger version of the traditional benchtop laboratory apparatus. A cylinder may take some time to warm to temperature. Then the $\mathrm{UF}_{6}$ is drawn into the plant systems where it is sent through the diffusion cascades. The effluent, enriched $\mathrm{UF}_{6}$, is cooled and then the liquid is poured into cylinders for truck or rail shipment to a fuel fabrication facility.

\subsection{Summary of Uranium Enrichment Events of Safety Importance}

The three gaseous enrichment plants have been reviewed for $\mathrm{UF}_{6}$ handling experiences because such experiences may be useful to any facility handling $\mathrm{UF}_{6}$. There is not much published information on the centrifuge pilot plant tests or the centrifuge facilities at Portsmouth.

There are some general articles in the literature about uranium hexafluoride safety. Hull (1979) discussed $\mathrm{UF}_{6}$ releases from diffusion plants. In the low-pressure sections of the plant, the safety concern is moist air inleakage with subsequent chemical reactions rather than releasing the hexafluoride. The analysis by Hull showed that releases occurred more often in the first few years of operation than later in the life of the three mature diffusion plants. Improvements in design, operation and maintenance led to the trend of decreasing releases. The releases were categorized by cylinders, valves, and piping manifolds (including the tubing referred to as pigtails which connect cylinders to the fixed piping). Hull discussed a few important events in each category. In a 1960 event, a cylinder was supposed to be connected to a low pressure system to draw off any noncondensable gases in the cylinder headspace before the cylinder was steam heated for process feed purposes. The cylinder was inadvertently connected to a high pressure feed line; the cylinder was cold $(\sim 20 \mathrm{C})$ and acted as a condenser to the hot feed gas. The cylinder was overfilled by an additional $766 \mathrm{~kg}$ of hexafluoride. The practice at the time was to isolate the cylinder and begin the heating process on a closed cylinder, letting the vapor headspace in the cylinder pressurize before opening the cylinder to the feed lines. When the overfilled cylinder was steam heated, it ruptured by internal hydraulic overpressure before operators were prepared to open the valve; there was less headspace than normal to accommodate the overpressure. The release into the building was brought under control by personnel who applied dry ice to cool the hexafluoride. The cylinder was kept cool for two days before it was removed. The cylinder was salvaged by welding a patch over the $0.95 \mathrm{~cm}$ by $10.2 \mathrm{~cm}$ crack.

Hull (1979) also discussed two valve events. In 1952, a UF 6 cylinder had been placed in a feed bath. The cylinder's hexafluoride had been heated to liquid state and the valve connected to the feed sampling manifold. As the operator attempted to open the valve to obtain a sample, the valve was leaking to the room. The operator closed the valve but the valve continued to leak and then the liquid pressure forced the valve stem and seat assembly out of the valve body. The building was evacuated and emergency personnel attempted to cool the cylinder with carbon dioxide fire extinguishers. The 
cylinder was then taken outside, the valve was plugged and the cylinder was cooled down with dry ice. In an event in 1953, a cylinder was being heated in a hot water bath vaporizer (autoclaves were installed later at Paducah). The operator began to move an overhead crane as part of a different task. The crane hook and sling struck the cylinder valve. The damaged valve immediately began to leak $\mathrm{UF}_{6}$; while attempting to close the valve, operators broke the valve from the cylinder. The release was stopped by driving a tapered wooden plug into the valve opening. Hull also described a pigtail incident. In 1955 , during a withdrawal operation, liquid $\mathrm{UF}_{6}$ was properly being poured into a cylinder. The cylinder was resting in a cart typically used to move cylinders. The cart axle broke during the filling operation and the cylinder rolled out of its saddle as the cart dropped to the floor. The withdrawal drain line emergency block valve was quickly closed by operators, stopping the loss of liquid from the plant, but the cylinder valve was flowing liquid as well. Visibility was obscured as the hexafluoride was reacting in the air. Emergency personnel managed to attach a hitch to the cylinder and drag it from the room with a crane. In better visibility, the cylinder valve was closed, stopping the release.

4.2.1 Portsmouth Gaseous Diffusion Plant. In March 1978, at the Portsmouth diffusion plant, a $\mathrm{UF}_{6}$ cylinder was breached during handling (ORO, 1978). The 10- and 14-ton cylinders were stored on cradles in storage lots. A mobile crane was used to stack the cylinders in the lots, and straddle carriers were used to move the cylinders to and from the plant. In the plant, bridge cranes were used to move the cylinders. On March 7, an operator using a straddle carrier had picked up a 14 ton cylinder $(1.2 \mathrm{~m}$ diameter by $3.7 \mathrm{~m}$ length) filled with liquid $\mathrm{UF}_{6}$ at $88 \mathrm{C}$ and $0.38 \mathrm{MPa}$. The operator drove the carrier to the cylinder's new location for cooldown in a storage lot, but the cylinder dropped from the load shoes as it was being lowered onto its wooden cradle; the carrier was in poor mechanical condition and had allowed the cylinder to fall. The cylinder wall was ruptured when it struck the cradle. Natural $\mathrm{UF}_{6}$ liquid was exposed to air and smoke engulfed the straddle carrier. The operator abandoned the carrier and informed his manager. The nearby buildings were evacuated. The emergency team arrived and covered the cylinder with tarps and then sand bags. Attempts to place dry ice at the rupture opening failed to 'freeze block' the leak. The cylinder was then covered with snow, which provided enough cooling to stop the $\mathrm{UF}_{6}$ release. The cylinder was patched, decontaminated, and then was unloaded. The total release was estimated to be $6,477.5 \mathrm{~kg}$ of $\mathrm{UF}_{6}$ feed material. Cleanup of the spill location recovered $551.7 \mathrm{~kg} \mathrm{U}$, for a net release of $5,925.8 \mathrm{~kg} \mathrm{U}$. At the time that mass released was valued at $\$ 272 \mathrm{k}$. There was no criticality concern since the $\mathrm{UF}_{6}$ was natural rather than enriched. Some of the hexafluoride reacted to create $\mathrm{UO}_{2} \mathrm{~F}_{2}$ particles that became airborne and dispersed to the atmosphere. There was some plateout on the plant site; the offsite release was considered to be negligible. After that event, the diffusion plants formulated a new policy to not move hot cylinders with straddle carriers. Only in-building cranes are allowed to move hot cylinders. After cooldown the cylinders could be moved with straddle carriers.

The NMED database had several hundred events for the Portsmouth gaseous diffusion plant. Some events were near misses, some were procedure violations, and some were process off-normal events. The recurring events to note were autoclaves 
whose safety instrumentation would shut down the steam flow due to high condensate level. The condensate drain lines or strainers tended to plug with rust and debris. While this is not a large safety concern, the $\mathrm{UF}_{6}$ was being held mid-process and the more fragile flexible connection (the pigtail) to the fixed system was being relied upon as a confinement barrier for a longer time. Over half of the NMED reports discussed criticality safety, namely loss of spacing between U-235 contaminated items, such as removed parts to be discarded, removed parts to be repaired, used high efficiency particulate air (HEPA) filters, chemistry samples, contaminated laundry items, dry active waste containers, liquid waste containers, large storage cylinders, and other items. The principles of criticality control - to control geometry/volume of uranium-bearing items, controlling neutron moderation, and controlling the uranium mass - serve well, since these reports described loss of only one of these measures and no inadvertent criticalities had occurred. A 1997 event described that two HEPA filters had been removed from service but the filters had been placed closer than $60 \mathrm{~cm}$ apart in the maintenance area. This violated criticality controls, but since the filters were only loaded with $\sim 30 \mathrm{~g}$ of uranium, and the critical mass of uranium for that configuration was over $700 \mathrm{~g}$, there was ample margin precluding criticality.

There were small, gram-scale leaks described in the NMED, from instrument lines, bellows, valve stems, compressor shaft seals, etc. The operators had a safety policy of "see and flee", so if they noted any type of leak, they were to flee the immediate area and quickly notify the control room. Then emergency personnel would be mobilized. Using personal protective gear the emergency crews could repair the leak. The dry ice freezing technique was often used.

On December 9, 1998 (NMED 981204), during normal operations, a cell began to behave abnormally; with vibration, pressure surges, and a temperature increase. Operators could not restore normal parameters and an exothermic reaction began in the gas cascade. The cell cooling system was overwhelmed and failed. The reaction breached the gas cascade to the cell, the cell was shut down, there was sufficient heat to actuate the automatic fire sprinkler system, and the on-site fire department had about two hours of firefighting. Firefighting was hampered by low water pressure to the foam eductor system. Staff injuries included minor smoke inhalation, and there were minor injuries from slipping on spilled lubricating oil; the fire department was not able to shut down the lube oil system to the cell. Radiological exposures were very low. The exothermic reaction was not specifically identified, the investigation team believed it could have originated from chemical deposits due to wet air inleakage or foreign material in the process lines. Equipment failure was believed to be the cause, either the compressor's impeller parts rubbing or impeller failure. Cochran (1999) commented on the possibility of uranium settling out into solid compounds in the cascade, such as $\mathrm{UO}_{2} \mathrm{~F}_{2}$, if moist air entered the cascade. A prime concern with this air inleakage would be the solid plugging the diffusion membranes, and at higher stages where the U-235 concentration is high, $\mathrm{UO}_{2} \mathrm{~F}_{2}$ plating is a criticality concern.

The plant descriptions in this chapter showed that these plants used a great deal of electrical power. The NMED database also showed that these facilities have had a few 
electrical fires, in motors and transformers, as well as transformer oil leaks. For example, Portsmouth had a substantial electrical substation fire (Goodyear, 1982). That event was outside the plant buildings, but other events have occurred inside the buildings.

Portsmouth also has entered some occurrence reports into the DOE Occurrence Reporting and Processing System. Many were the same types of events as in the NMED, namely small losses of hexafluoride, lost production time, security infractions, etc. Two events were noteworthy in the $\sim 50$ submitted reports. In 1993, a compressor debladed during startup operations (ORPS, 1993). The diffusion cell was started according to procedures and was pressurizing with $\mathrm{UF}_{6}$ up to $0.2 \mathrm{MPa}$ when the staff noted an alarm that the compressor motor current had dropped from its typical 280 amperes at that pressure. The motor current was only 50 amperes. The staff shut down the motor and operators investigated the cell to find that there was no outgassing, fire, or external equipment damage. The process gas was bled into the cascade from this cell and preparations were made to hand the cell over to maintenance to replace the compressor. The axial flow compressor was part of the original equipment procurement in 1955, had been rebuilt in 1959 and was modified in 1983. Investigators believed that the failure was equipment or material related, meaning a failed part, since there was no operational challenge or stress on the compressor when it debladed. The report also cited five other compressor deblade events in the past few years. This event does suggest that high speed rotating parts do eventually fatigue and can fail. Fortunately the event was not a catastrophic loss. There was no fire, and the compressor had served a long useful lifetime of over 35 years. The issue of reliability of high speed rotating parts is also a concern for the many stages of rotating gas centrifuges.

Another occurrence report described a failure of a valve in the secondary side of a condenser in a cell (ORPS, 1993a). The condenser removes heat from the $\mathrm{UF}_{6}$ process gas. An operator was placing a valve identification tag on a $3.8 \mathrm{~cm}(1.5$-inch) strainer blowdown valve in the condenser water system. The valve began to leak. The operator tried to tighten the valve on its threads to stop the leak, but the valve separated from its nipple. Water at $0.36 \mathrm{MPa}$ and $\sim 32 \mathrm{C}$ flowed from the $3.8 \mathrm{~cm}$ opening in the strainer. The operator called for assistance and the cell was shut down. Fortunately, the water was not contaminated and the operator was not injured. A taper plug was inserted into the leak opening and a water wagon was moved into place to catch any leaking water, but it was not needed after the taper plug was installed. The valve was replaced and the cell returned to service in about 10 hours. The valve's steel nipple had corroded. The staff is aware of corrosion issues and had placed corrosion inhibitor in the condenser water, but in static areas the concentration of the inhibitor decreases over time and allows corrosion to proceed. This event shows the dependence of the process on the secondary systems; the support systems must be as reliable as the primary systems to keep the plant operational. This event was dealt with in a timely fashion, proceeding from the initial failure event to water spill, then repair and back to operation in only 10 hours.

Some other Portsmouth events included $\mathrm{UF}_{6}$ losses (DOE, 1980). On April 10, 1975, a compressor in the Extended Range Product Station failed and caused the release of $12 \mathrm{~kg}$ of uranium $(0.372 \mathrm{~kg}$ was enriched uranium). The release remained within the 
building. The estimated cost of the property loss was \$29k (in 1975 dollars). On November 10,1975, $10.5 \mathrm{~kg}$ of enriched uranium hexafluoride was released in the High Assay Sampling Area of the plant. A pigtail valve connector leaked when the sample valve was opened. The room exhaust fans failed to shut down immediately, and extensive contamination of the building resulted. The property loss was $\$ 101 \mathrm{k}$ (in 1975 dollars) (DOE, 1980).

4.2.2 Oak Ridge Gaseous Diffusion Plant. The Oak Ridge Gaseous Diffusion Plant was the first US facility to be constructed and also the first to be closed. Much of its operation was kept secret due to national defense needs. Johnson (1994) stated that over 12,000 employees operated the plant. Only a few off-normal events were found in the literature. On November 17, 1960, a ten-ton hexafluoride cylinder ruptured. The report did not give any details, but the cost of the event was \$103k in 1960 dollars. In 1965, while people performed conversion of uranium oxide to uranium hexafluoride, eight employees received lung depositions resulting in lung doses of 36, 29, 25, 22, 22, 21, 20 and $16 \mathrm{rem}$. On May 2, 1973, an employee was attempting to take a liquid sample from a ten ton $\mathrm{UF}_{6}$ cylinder. The cylinder began to leak. The leak lasted for $\sim 20$ minutes and released 215 pounds of hexafluoride (AEC, 1975). On September 17, 1975, a cylinder had just been filled with $3.28 \%$ enriched $\mathrm{UF}_{6}$ and while the $\mathrm{UF}_{6}$ was liquid the cylinder was transported by forklift to a storage pad outside of the building. After the cylinder was lowered to the pad, an explosion occurred inside the cylinder, so that the concave ends of the cylinder bulged outward. Smoke began to emerge from a crack that had formed in the valve body and also from a crack that formed in the cylinder wall. One operator was slightly injured when his hand was struck by a lifting hook that was propelled away from the end of the cylinder. The other operator received a knee laceration and was knocked to the ground when he was struck by the cylinder's identification plate that was ejected away from the cylinder end when the end bulged outward. The man's fractured knee cap and partially severed tendon proved to be a disabling injury. The explosion occurred due to hydrocarbon contamination in the cylinder. A motor failed on a mechanical vacuum pump that was used to evacuate the cylinder and the failure allowed pump oil migration into the cylinder. The oil intrusion was not noticed and the cylinder was loaded with hexafluoride. Emergency response personnel sprayed $\mathrm{CO}_{2}$ from portable fire extinguishers and later packed the cylinder with dry ice to cool the cylinder and bring the release under control. About 18 pounds of enriched $\mathrm{UF}_{6}$ (a cost of about $\$ 5 \mathrm{k}$ ) were released before the cylinder was cooled and brought under control. Employees submitted bioassay samples to test for uranium uptake. The highest reading was $17 \%$ of the quarterly exposure limit, and most employees tested at less than $1 \%$ of the quarterly exposure limit (Legeay, 1986).

4.2.3 Paducah Gaseous Diffusion Plant. The Paducah plant has not filed many occurrence reports or NMED reports. An explosion event occurred on December 13, 1962 in a cell at the plant. Following the explosion, an intense localized chemical reaction fire caused heavy damage to the cell. Water from the automatic sprinkler system was turned to steam and this steam caused over 2,000 other water sprinkler heads to open. It is unlikely that any other plant would have had enough water supply to operate 2,341 open sprinkler heads. Over 2.8 M gallons of water were consumed. Despite the 
high water usage, the plant was $90 \%$ back in operation within 4 days (DOE, 1982). The Paducah plant also had a 2,000 horsepower motor short circuit and ignite when starting up on December 13, 1976. Twenty sprinklers opened to flow water, and the fire department completed extinguishment (DOE, 1982). Other literature discussed an occupational fatality in 1977 (DOE, 1980). On February 16, 1977, an electrical mechanic trainee contacted an energized section of an electrical substation with a metal tool. The trainee sustained third degree burns from the resulting electrical fault; he perished about eight hours later. The electrical fault and subsequent fire caused extensive damage to the substation equipment, estimated at $\$ 50 \mathrm{k}$ (in 1977 dollars). Another event was an explosion that occurred in the Tails Withdrawal Facility on January 3, 1978 (DOE, 1980a; DOE, 1982). An automatic recycle valve failed to operate properly in the uranium hexafluoride compression loop during a large inventory shift in the cascade. Mechanical damage, chemical reactions, and hydraulic rupture of the gas coolers permitted release of the coolant inventory and combustion of some of the release. The uranium hexafluoride release was less than 30 pounds $(66 \mathrm{~kg})$. No employees were injured, but the explosion caused extensive equipment loss, estimated at $\$ 200 \mathrm{k}$ (in 1978 dollars). The sprinkler system was credited with controlling the fire and preventing the loss of the entire facility (DOE, 1982).

These events have illustrated several important issues with the enrichment plants. There are always equipment failures that can lead to degraded safety (i.e., failed monitors) and to small releases (pipe leaks, compressor deblading, etc.). There are some concerns over criticality of the enriched uranium, especially nuclear material accumulating in undesignated areas. Releases of non-radioactive chemicals used in the processes; for example, hydrogen or fluorine, are safety issues, and the release of uranium hexafluoride has caused health effects. 


\section{Chapter 4 References}

AEC, 1975. Operational Accidents and Radiation Exposure Experience within the United States Atomic Energy Commission, 1943-1975, WASH-1192, US Atomic Energy Commission, Fall 1975.

Arthur, 1980. W. B. Arthur, Description of the Portsmouth Gas Centrifuge Enrichment Plant, K/OA-4783, Union Carbide Corporation, Oak ridge, Tennessee, December 1980.

Cochran, 1999. R. G. Cochran and N. Tsoulfanidis, The Nuclear Fuel Cycle: Analysis and Management, second edition, American Nuclear Society, La Grange Park, Illinois, 1999, chapter 3 .

DOE, 1980. Operational Accidents and Radiation Exposures at ERDA Facilities, 19751977, DOE/EV-0080, US Department of Energy, May 1980.

DOE, 1980a. Operational Accidents and Radiation Exposures at DOE Facilities, Fiscal Year 1978, DOE/EV-0091/1, US Department of Energy, 1980.

DOE, 1982. Automatic Sprinkler System Performance and Reliability in United States Department of Energy Facilities, 1952-1980, DOE/EP-0052, US Department of Energy, June 1982.

Goodyear, 1982. Investigation of Auxiliary Power Substation 95A4 Fault and Fire, Portsmouth Gaseous Diffusion Plant, March 24, 1982, GAT/GDP-1100, Goodyear Atomic Corporation, June 1982.

Hull, 1978. G. T. Hull, $\underline{U F}_{6}$ Release Experience and Prevention in United States Gaseous Diffusion Plants, KY-690, CONF 780669-2, Union Carbide Paducah Gaseous Diffusion Plant, June 1978.

Johnson, 1994. L. Johnson and D. Schaffer, Oak Ridge National Laboratory: The First Fifty Years, University of Tennessee Press, November 1994.

Legeay, 1986. A. J. Legeay et al., Investigation of a Uranium Hexafluoride Release Incident on September 17, 1975 in the K-1423 Toll Enrichment Facility, K/P6197, revision 1, Union Carbide Corporation, Oak Ridge Gaseous Diffusion Plant, Tennessee, April 16, 1986.

LLNL, 1995. This is Gaseous Diffusion, how a gaseous diffusion plant operates, UCRLAR-122154, Lawrence Livermore National Laboratory, September 1995.

NRC, 1994. Safety Evaluation Report for the Claiborne Enrichment Center, Homer, Louisiana, NUREG-1491, US Nuclear Regulatory Commission, 1994. 
NRC, 1994a. Final Environmental Impact Statement for the Construction and Operation of the Claiborne Enrichment Center, Homer, Louisiana, NUREG-1484, US Nuclear Regulatory Commission, 1994.

NRC, 1998. Analysis and Evaluation of Operational Data, 1997 Annual Report Nuclear Materials, NUREG-1272, Volume 11, Number 2, US Nuclear Regulatory Commission, November 1998.

ORO, 1978. Investigation of Occurrence Involving Release of Uranium Hexafluoride from a Fourteen-Ton Cylinder at the Portsmouth Gaseous Diffusion Plant on March 7, 1978, ORO-757, US Department of Energy Oak Ridge Operations Office, June 1978.

ORPS, 1993. Cell 31-4-2 Stage 1 Compressor Deblade - PTS-3-053, ORPS number ORO-MMES-PORTCASOPS-1993-0005, US Department of Energy, February 8, 1993.

ORPS, 1993a. Loss of Production of "000" Cell 33-3-6, X-333 Process Building, Failed Recirculating Condenser Water Strainer Blowdown Valve PTS-93-62, OROMMES-PORTCASOPS-1993-0008, US Department of Energy, February 13, 1993.

Wilson, 1996. P. D. Wilson, The Nuclear Fuel Cycle, from Ore to Wastes, Oxford University Press, Oxford, UK, 1996, chapter 3. 


\section{URANIUM FUEL FABRICATION}

The enrichment plant produces enriched uranium hexafluoride, usually up to 5\% enrichment, and the cylinders of solidified hexafluoride are transported by rail or truck to the fuel fabrication plant. The fuel fabrication plant converts the pure, enriched $\mathrm{UF}_{6}$ into $\mathrm{UO}_{2}$ for production of reactor fuel. This second conversion process is simply changing the chemical compound, there is no purification of the $\mathrm{UF}_{6}$.

\subsection{Brief History and Description of Uranium Fuel Fabrication}

The large scale manufacture of nuclear fuel in the United States has been focused on three major types:

- Low enriched fuel for commercial light water power reactors (pressurized and boiling water)

- Defense fuels (low enriched) for production of nuclear weapons materials

- Naval fuels (more highly enriched) that power America's aircraft carriers and submarines

The fuel for the defense materials production reactors located at DOE's Hanford and Savannah River Sites used an aluminum cladding. These reactors were low temperature/low pressure reactors, which made use of aluminum possible, and use of the aluminum clad helped in the dissolution of the irradiated rods for subsequent recovery of the weapons materials. The fuel rods were made on-site, but these reactors are no longer in service; consequently aluminum clad fuels are no longer being fabricated.

Naval fuels are a very specialized fuel fabricated to power the nuclear naval vessels. These contain more highly enriched uranium and are currently fabricated at two facilities in the United States. Neither the defense nor the naval spent fuels will be considered under the AFCI program.

The fuel for commercial light water power reactors (LWRs) comprises by far the largest percentage of fuel manufactured and utilized in the United States and will be the focus of the AFCI. This fuel typically begins with receipt of low-enriched uranium (LEU) hexafluoride $\mathrm{UF}_{6}$ from an enrichment plant. The LEU usually contains $5 \%$ or less of U-235. The enriched $\mathrm{UF}_{6}$ is transported to a fuel fabrication plant where it is converted to uranium dioxide $\left(\mathrm{UO}_{2}\right)$ powder using an integrated dry route process or ammonium diuranate (ADU) conversion. The $\mathrm{UO}_{2}$ powder is then pressed into small pellets, sintered to final density, and ground to final diameter. These pellets are inserted into thin tubes, usually composed of a zirconium alloy (zircalloy) or stainless steel, to form fuel rods. The rods are then sealed and assembled in clusters to form fuel elements or assemblies for use in the nuclear reactor core. The $\mathrm{UO}_{2}$ fuel fabrication process is strictly regulated by the NRC. 
For the near-term, commercial fuel will also be made using high-enriched uranium (HEU) that has been declared excess from the U.S. and Russian military programs. This "blend-down" program takes weapons-grade HEU and dilutes it down to LEU specifications so it is no longer readily useable for nuclear weapons. This demilitarized uranium can then be fed directly into standard fuel fabrication process for LWR's.

Fuel assemblies, while similar, are designed to meet the specific requirements of each nuclear reactor. To ensure that each fuel assembly performs to its design criteria over its lifetime, fuel fabricators employ stringent quality control measures throughout the production process. The completed fuel assemblies are delivered to the energy companies that have ordered them. Several hundred fuel assemblies make up the core of a reactor. For a commercial reactor with an output of 1,000 megawatts (MWe), the core would contain about 75 metric tons of low-enriched uranium. Some 25 metric tons of fresh fuel is required each year by a 1000 MWe reactor.

Three companies in the United States provide fabrication services for low enriched fuel for commercial power reactors: Framatome ANP Inc. in Lynchburg, Virginia and Richland, Washington; Global Nuclear Fuel in Wilmington, North Carolina; and Westinghouse Electric in Columbia, South Carolina and Hematite, Missouri. Essentially all U.S. fabrication demand is met by these five facilities. Two additional facilities, operated by BWXT in Lynchburg, Virginia, and Nuclear Fuels Services, in Erwin, Tennessee, produce HEU fuels for the U.S. Navy. All of these private companies are licensed by the NRC and operate in accordance with their regulations (NRC, 2005).

\subsection{Summary of Uranium Fuel Fabrication Events of Safety Importance}

The significant potential accidents at fuel fabrication facilities are $\mathrm{UF}_{6}$ releases, fires, and criticality accidents - the latter being an unintended, self-sustaining nuclear chain reaction. In general, there is likely to be little or no warning before these accidents begin. However, they are likely to be controlled within roughly half an hour in a majority of cases. Thus, quick decisions and prompt actions are necessary.

Nuclear Fuel Services, Inc., while a high enriched uranium facility, reported an event of importance to all facilities. On October 5, 1984, the company informed the $\mathrm{NRC}$ that an excessive buildup of uranium had been discovered in the new ventilation system, including a venturi scrubber, of the scrap recovery facility at their plant (NRC, 1985). The new ventilation system had been operating less than 1.5 years. It had been installed to reduce the level of radioactive effluents and offsite losses. In July 1983, a heat exchanger was removed from the system and was later found to contain several hundred grams of U-235. Action limits of uranium were set in the operating license, and these limits were exceeded on several occasions in 1984. On October 3 and 4, 1984, the company detected uranium concentrations above the limits in the venturi scrubber solution. The venturi was opened and inspected. About $1 \mathrm{~kg}$ of U-235 was found to have accumulated on the scrubber walls, and about $1 \mathrm{~kg}$ of U-235 was accumulated in the duct leading to the scrubber. Analysis showed that a criticality event could not have occurred 
in this situation, but the amount of U-235 was considerably greater than a safe mass. About $1.6 \mathrm{~kg}$ of U-235 was removed mechanically, and another $0.6 \mathrm{~kg}$ was removed by water flushes. The scrubber design was meant to capture all solid material entering with the air, but the existence of acid and moisture in the scrubber allowed the solid material to deposit on the ducting above the scrubber solution. The most significant sources of uranium were considered to be the scrap furnace and the scrap dissolvers, and it was also possible that the HEPA filters on other process equipment may have leaked. After the safety concern of criticality, other concerns included the fact that special nuclear material was not maintained within a material balance area and was not measured during physical inventories, and the material in the duct and scrubber was not stored properly.

The NRC has reported several events of importance in fuel fabrication plants. In 1986, the Nuclear Fuel Services plant reported that they had experienced a fire in the reserve hydrogen tube trailer outside the process buildings (NRC, 1987). In 1987, two events of importance occurred; in one event, nitrogen gas service to operating equipment was interrupted, and air replaced the nitrogen. A series of small explosions occurred when the air mixed in hydrogen blanket gas, damaging some equipment. In a second event, a scrap furnace exploded when combustible liquid was being processed. The furnace temperature volatilized the material and ventilation failure (due to plugging) allowed the gas to accumulate and explode (NRC, 1988). These events show the combustible nature of the chemicals and chemical processes in these facilities. In 1989, the Allied Signal plant in Metropolis, Illinois reported that a 125,000 gallon hydrofluoric acid storage tank ruptured. The tank had contained about 33,000 gallons of $0.36 \% \mathrm{HF}$ solution at the time of the rupture, about $80 \%$ of that was contained in the diked area. The liquid contained only 5 ppm of Fluoride ion, which was below the Environmental Protection Agency limit. In the same year, the Babcock and Wilcox plant reported a flash fire that ignited zirconium fines; the fire self-extinguished in $\sim 30$ seconds. The process operator was contaminated but there was no off-site release (NRC, 1990). In 1990, the General Electric plant in Wilmington, NC reported a fire in the containment ventilation of a slugger press (NRC, 1991). These events illustrate the pyrophoric nature of finely divided metals

A review of the NMED database provided 117 events related to fuel fabrication facilities in the United States from 1990 to 2004. These events were categorized to assist in a discussion of their general nature and the lessons learned that should be applied to the AFCI program facilities. Possible design attributes to prevent recurrence are discussed in each section with the guiding premise that effective engineering design, instead of operator action/intervention, will be used where practicable to maintain the facility within its safety envelope.

There has never been a criticality incident during the fabrication of LEU power reactor fuels in the U.S. Most fuel fabrication activities utilize $\mathrm{UO}_{2}$ powder so criticality is controlled by maintaining sub-critical quantities of uranium dioxide in favorable geometry containers while excluding moderator. This double contingency of 
geometry/volume control and moderator control maintains safety in the facilities. The types of incidents from the NMED data are as follows:

Criticality of solids due to spills: There were 23 occurrences where equipment malfunctions led to substantial accumulations of $\mathrm{UO}_{2}$ powder in areas that had not been evaluated for favorable geometry. In most cases less than a critical mass accumulated and in all cases moderator control remained intact. Unplanned accumulation of material is inevitable when handling powders/pellets due to either equipment failures or small chronic losses. Design attributes that should be considered are:

- Any voids that could accumulate materials within dust covers and equipment should be evaluated for favorable geometry.

- $\quad$ Equipment should be designed for easy inspections to assure no accumulation of materials.

- Critical instrumentation monitoring levels/materials should be redundant or failsafe.

- Software controlling processes should monitor material balances and note/alarm discrepancies.

Criticality of solids due to proximity: On nine occasions, operators either placed materials into containers that did not have favorable geometries or placed uranium bearing product or equipment too close together. When relying on operating procedures or analysis of materials to maintain criticality control, there is an opportunity for a mistake or oversight. Design attributes that should be considered are:

- $\quad$ Equipment configuration should allow only containers of suitable geometry to be filled.

- $\quad$ Physical spacers should be built into containers and equipment to assure suitable spacing for criticality control.

Moderator control: Moderator control provides one half of the double contingency for control of criticality in fuel fabrication facilities. None of the nine incidents in the NMED data search resulted in criticalities but were classified as loss of double contingency. They included lack of moisture analyses of powder batches, minor liquid traces on/in powder containers and minor equipment or facility leaks. Design criteria that should be considered are:

- Double containment of piping

- $\quad$ Elimination or minimization of moderator

Criticality of solutions: Only 4 events were noted on control of uranium solutions in US fuel fabrication facilities. Most of these involved the ADU wet process for conversion of $\mathrm{UF}_{6}$ to $\mathrm{UO}_{2}$. Although no criticalities occurred in these events, the Japanese Tokai Mura plant had a criticality on September 30, 1999. They were using the same process while restarting a fuel-making operation for the JOYO reactor for the first 
time in three years. This event was caused by gross failure to follow procedures to increase production throughput. Multiple buckets of uranium solution were poured into an unfavorable geometry vessel. The enriched solution reached critical mass and went prompt critical resulting in the deaths of two workers (Suzuki, 2000). Due to the concerns of using enriched uranium solutions, many fuel fabrication plants have changed to a dry process thus removing moderator from the process and further minimizing the chance for criticalities. Suitable design criteria include:

- Use of dry processes where applicable

- Use of only favorable geometry vessels in process equipment

- $\quad$ Physical interlock or isolation to prevent transfer of solutions to unfavorable geometry tankage.

Controls: Seven events were related to control of critical materials or monitoring of critical processes/data. Failure of controls or improper configuration control contributed to most occurrences. Control of facility configuration is closely managed and these occurrences are rare. Design attributes that are traditionally applied to nuclear facilities will be applicable to AFCI facilities, including:

- Controls and equipment failing in a safe configuration (fail safe)

- Redundant controls for critical instrumentation

Fires: A total of 14 minor facility fires were reported in the database; eight involved uranium materials, five were general facility fires and one was an equipment fire. Material fires are of concern for uranium materials and will be more problematic for fuel bearing plutonium, americium, curium, and neptunium.

Procedural: Approximately 11 occurrences were wholly or partially attributed to procedural violations. Any operations aspects of fuel fabrication will continue to rely on effective training, compliance with procedures and management oversight. The AFCI should investigate all aspects of facility designs that eliminate or minimize any risks due to operator error. It is especially important with criticality control. Judicious application of nuclear design should strive to eliminate unfavorable geometry vessels, exclusion of moderator, redundant critical instrumentation and effective software material control and accountability to detect any potential process losses that may indicate potential accumulations of critical materials.

Releases: Releases were limited to $\mathrm{UF}_{6}$ gaseous emissions from the vaporization of $\mathrm{UF}_{6}$ to convert it to $\mathrm{UO}_{2}$. All seven releases were minor with little or no health impact to on and off-site personnel. Due to close proximity, operations personnel are at greatest risk of exposure and additional design considerations may include improved ventilation and enclosures around the $\mathrm{UF}_{6}$ vaporization equipment.

Shipping Violations: Ten events were related to shipments of materials. Three of these concerned slightly elevated surface contamination or radiation levels. Three were incomplete container certification or documentation. The most serious events were the inadvertent shipment of $1684.2 \mathrm{w} \%$ fuel pellets in a shipment of scrap zirconium tubes 
and the omission of two neutron absorber plates in a shipment of assemblies with enrichment greater than $4.65 \mathrm{w} \% \mathrm{U}-235$. Although these events did not lead to any transportation occurrences, they are important because of their close interaction of the public with these materials. High assurance of compliance with shipping regulations is important to maintain a high level of confidence in the public sector. Most often shipping violations occur due to non-compliance with procedures so there may be few opportunities to improve this performance through prudent design. One opportunity for improvement is to design shipping containers with absorber plates and/or shielding that is integral or interlocked such that the container cannot be closed without them.

Related Occurrences: Lessons learned from two occurrences from processes closely related to fuel fabrication are applicable to fuel fabrication.

1. Event: On May 29, 1991 at the General Electric Company's Nuclear Fuel and Components Manufacturing facility, an estimated 150 kilograms of uranium in solution was inadvertently transferred into tanks with unfavorable geometry (NRC, 1991a). Problems with a level control valve in a solventextraction column led operators to force the valve open and this caused the process to be ineffective. From the onset, feed material continued to enter the column, creating a large volume, high concentration uranium solution that was directed to two favorable geometry aqueous waste quarantine tanks. Sampling problems, including no samples on 4 operations, led to the transfer of 9 volumes of the waste quarantine tanks to be pumped to the unfavorable geometry waste accumulation tank. When the control received a quarantine tank sample of 6,977 ppm uranium (versus the transfer limit of $150 \mathrm{ppm}$ ), the control room operator immediately shut down the solvent-extraction process. Meanwhile, another operator unaware of the process upset, transferred the 20,000 gallons of solution in the waste accumulation tank to a second unfavorable geometry tank at the Waste Treatment Facility. Once the high concentration of uranium was discovered, operators initiated air sparging of the tanks to minimize criticality potential in the tanks due to precipitate settling. A technical evaluation team was assigned, the NRC was notified, an Alert emergency classification was made to authorities and uranium recovery plans using centrifuges were initiated. After approximately 48 hours, the contents of the tanks were reduced to less than critical mass and the alert was terminated. It took approximately two days to complete the uranium recovery operation.

Design Impact: This will only be a concern at fuel fabrication facilities if aqueous processing is utilized for functions such as scrap recovery. The use of favorable geometry vessels should be required when the potential exists for introduction of solutions with a high concentration of fissile materials during both normal operation and worst case off-normal operating conditions. 
2. Event: January 4, 1986, an overfilled cylinder containing $\mathrm{UF}_{6}$ ruptured while it was being heated in a steam chest at the Sequoyah Fuels Conversion Facility near Gore, Oklahoma (NRC, 1986; NRC, 1986a). One worker died because he inhaled hydrogen fluoride fumes, a reaction product of $\mathrm{UF}_{6}$ and airborne moisture. Several other workers were injured, but none seriously, and there was on-site and off-site contamination with hydrogen fluoride and uranyl fluoride, a second reaction product. One root cause was traced to a weighing error during the filling of the cylinder. One wheel of the cylinder cradle was not completely on the scale, which caused a low reading of the weight. Cylinder filling continued until the scale indicated the proper weight, when in fact, the cylinder was much heavier and contained an excess quantity of $\mathrm{UF}_{6}$. When the cylinder was found to be overfilled, a supervisor directed operators to place the cylinder in a steam jacket to speed product removal. This second causal factor was in violation of company procedures that do not allow over-filled cylinders to be placed in steam jackets.

Design Impact: Facility design should address ventilation of $\mathrm{UF}_{6}$ releases. Scale designs should incorporate physical guides to prevent incorrect positioning of cylinders on the scales. 
Chapter 5 References

NRC, 1985. Report to Congress on Abnormal Occurrences, October-December 1984, NUREG-0090-V7-N4, US Nuclear Regulatory Commission, May 1985, pages $10-12$.

NRC, 1986. Rupture of Model 48Y UF 6 Cylinder and Release of Uranium Hexafluoride (Sequoyah Fuels Facility, Gore, Oklahoma, January 4, 1986), NUREG-1179, US Nuclear Regulatory Commission, 1986.

NRC, 1986a. Assessment of the Public Health Impact From the Accidental Release of $\underline{\mathrm{UF}}_{6}$ at the Sequoyah Fuels Corporation Facility at Gore, Oklahoma, NUREG1189, US Nuclear Regulatory Commission, 1986.

NRC, 1987. Report to the US Nuclear Regulatory Commission on Analysis and Evaluation of Operational Data - 1986, NUREG-1272, Us Nuclear Regulatory Commission, May 1987.

NRC, 1988. Report to the US Nuclear Regulatory Commission on Analysis and Evaluation of Operational Data - 1987, NUREG-1272, Volume 2, Number 2, Us Nuclear Regulatory Commission, October 1986.

NRC, 1990. Analysis and Evaluation of Operational Data, 1989 Annual Report Nonreactors, NUREG-1272, volume 4, number 2, US Nuclear Regulatory Commission, July 1990.

NRC, 1991. Analysis and Evaluation of Operational Data, 1990 Annual Report Nonreactors, NUREG-1272, volume 5, number 2, US Nuclear Regulatory Commission, July 1991.

NRC, 1991a. Potential Criticality Accident at the GE Nuclear Fuel and Component Manufacturing Facility, May 29, 1991, NUREG-1450, US Nuclear Regulatory Commission, 1991.

NRC, 2005. Information Digest, 2004-2005 edition, NUREG-1350, volume 16, revision 1, US Nuclear Regulatory Commission, February 2005.

Suzuki, 2000. A. Suzuki, "Causes of the JCO criticality accident and lessons learned," Nuclear Energy, 39 (2000) 373-380. 


\section{URANIUM FUEL REPROCESSING}

After the fuel is fabricated, it is shipped to a commercial nuclear power plant and it is used in the reactor core. After perhaps 24 or 36 months, the U-235 has been fissioned, or 'burned', to the extent that it is no longer plentiful enough to operate well in the reactor. Cochran (1999) stated that spent fuel is typically on the order of 0.6 to $0.8 \%$ $\mathrm{U}-235$, from an original 4 or $5 \% \mathrm{U}-235$. The spent fuel is removed and allowed to cool down. That is, time to allow the short-lived fission products to decay, giving up some energy and heat in the process. The fuel is still in fuel elements, that is, in uranium oxide pellet form, inside tubes of zircaloy cladding and arrayed as fuel elements. Most of the fission products are trapped in the $\mathrm{UO}_{2}$ matrix within each pellet. To reclaim the useful uranium, it must be chemically separated from the fission products and the rest of the spent fuel. The weight percent is nearly that of natural uranium, but reclaiming the U235 from spent fuel would reduce the mining needed to obtain new uranium.

\subsection{Brief History of Uranium Fuel Reprocessing}

The nuclear industry was born in the effort to produce nuclear weapons during World War II. The first fuel reprocessing efforts had the goal of separating and removing plutonium from the irradiated uranium fuel. The first separations plant was the Hanford Works, near the Columbia River at Hanford, Washington (DOE, 2003). The DuPont chemical company was chosen to build and operate Hanford because the large company had the design, construction, and operations experience to do the job (Mottel, 1995). The separation process was based on chemical separation. At that time, the focus was only on obtaining the plutonium. During the Cold War the scope expanded to also retrieve the uranium from the irradiated fuel. The chemical separations were credited with generating the most mass and the most hazardous waste; an estimated 10,000 gallons of liquid waste for every metric ton of uranium fuel processed (DOE, 2003). Over the years at Hanford, three types of separations processes were used: the initial bismuth phosphate batch processing, solvent extraction through reduction oxidation reactions, and solvent extraction through plutonium-uranium extraction, called PUREX.

Irradiated fuel was usually allowed to decay, in a temporary storage location often referred to as "lag storage". This was simply to allow short-lived radionuclides time to decay to low levels. Some short-lived radionuclides, like I-131 (half-life of $\sim 8$ days), are significant safety concerns to personnel. During the war, cooling times were on the order of only 15 to 30 days, but after the end of the war, times expanded to $\sim 50$ days. During the Cold War, the irradiated fuel storage periods were between 90 to 120 days (DOE, 2003).

After fuel element cool down, the fuel elements would be moved in water-filled, shielded casks and conveyed by on-site rail to a 'canyon' facility. A canyon is a concrete trench inside a processing building where casks or the irradiated material was handled, usually by remote cranes or manipulators. This wartime, large-scale use of reach rods, shielded operations booths on cranes, remotely operated cranes, and manipulators, was the birth of remote handling in the nuclear industry. For the initial bismuth phosphate 
batch processing, the irradiated materials would be loaded into water-filled dissolver tanks. At Hanford the limit was about 3 tons of fuel elements per tank. The tank was sealed and concrete shielding was replaced on top of the tank. The next step at Hanford was to verify that the prevailing weather conditions at the site were conducive to atmospheric dilution. If so, then processing could proceed. Processing first heated the dissolver tank contents with steam heat coils, then introduced a caustic agent, such as sodium hydroxide, to dissolve the aluminum cladding without reacting with the uranium. Monitoring the specific gravity of the tank contents indicated when the reaction was complete. The aluminum solution was then transferred to a waste tank and the dissolver tank was rinsed with water. Next, nitric acid was added to dissolve the uranium and form uranium nitrate. Several batches of acid would be needed to dissolve all of the uranium. The heat of reaction would boil the liquid in the tank. Any remaining uranium not reacted or not transferred out of the tank would be the 'heel' of the tank. The heel had to be monitored to track uranium accumulation. The dissolver tank would vent any fission product gases (I-131, Xe-135, Krypton, etc.) and nitrogen oxides to a stack at that point, hence the need for weather conducive to atmospheric dilution. Note that this was a wartime design whose sole purpose was to arrive at nuclear weapons before the Axis powers; later designs did not vent to the atmosphere to the extent that this initial system vented. The plutonium nitrate would be separated from the uranium nitrate and the fission products by the bismuth phosphate precipitation agent. Bismuth phosphate was the first laboratory scale process that showed promise for large scale operations, it was used even though it did not salvage the uranium and it created high levels of waste. The planners under wartime emergency did not consider the post-war world or the possible need for more weapons (DOE, 1997; Reed, 2002), their goal was to produce enough plutonium for a few weapons, and, if need be, continue making a few weapons for use until the Axis powers capitulated. The bismuth phosphate initial process was replaced in the 1950's by the continuous solvent extraction process; the continuous process using hexone was more economic and more efficient at extracting plutonium. Also, the 8-story tall slender columns allowed processing of individual fuel elements without concern for nuclear criticality (DOE, 1997; Benedict, 1957). The continuous reduction oxide process (REDOX) meant a constant stream flow in a dissolver column instead of sealing a dissolver tank and processing a batch (Reed, 2002).

Extraction columns were used, where the aqueous acid solution entered at the top of the column, and the organic phosphate solution entered at the bottom of the column. As the immiscible solutions passed each other as they traversed the column, and the fuel element was dissolving in the column, uranium or plutonium would be selectively reacted out of one stream and enter the other stream. In the continuous process, the off gases would be cooled in a condenser, to retrieve nitric acid vapor for reuse, then the remaining gases would be steam heated and routed to a column with silver nitrate. The silver nitrate would react with the iodine gas, forming silver iodide. In that way, some of the iodine was trapped in the column instead of being released to the air.

The solvent extraction processes are similar to the yellow cake purification processes described earlier in this report, with the exception that fuel reprocessing involves more steps because there are more elements involved (i.e., the spectrum of 
fission products) and the very high decontamination factors needed to arrive at very pure uranium to be used in new fuel fabrication (Benedict, 1957). New fuel should not have any fission product delayed neutrons present. An important issue is that the fuel reprocessing chemically based steps separate one element from another. Once the uranium is chemically separated, there could be U-232, U-233, U-235, and U-238 isotopes. When the reprocessed uranium returns to a gaseous diffusion plant, the nuclides lighter than U-235 will pass through enrichment quite easily. Likewise, when plutonium is chemically separated, there could be $\mathrm{Pu}-238, \mathrm{Pu}-241$, etc., in the plutonium stream.

Benedict (1957) discussed some of the issues with various solvents, such as hexone (methylisobutyl ketone) in the reduction oxide process. There are flammability hazards due to the low flash point of the hexone solvent vapor (that is, the low temperature that a flame will begin to burn in the vapor above the liquid solvent, the hexone flashpoint is $27 \mathrm{C}$ ), the solvent had losses due to solubility in the aqueous solution, and the hexone was unstable when mixed with concentrated nitric acid. However, the nitric acid had to be concentrated to dissolve the fuel and form nitrates. Impurities in commercially available hexone also posed problems for successful removal of zirconium and cerium. Highly impure hexone would have to be purified in another multi-step process.

TBP solvent was used in place of hexone in the PUREX process. The TBP is less toxic, less flammable, and more easily handled than hexone, and the TBP usage precluded the need for a salting agent, which reduced the amount of radioactive solids sent to waste disposal. The TBP is less soluble in water, fewer liquid-liquid contact steps were needed to decontaminate the process liquid, and most of the nitric acid would be recovered for reuse (Benedict, 1957). The TBP process did have difficulty in adequately removing zirconium, then niobium, and finally ruthenium. The TBP was an improvement over the REDOX method in terms of versatility, reduced operating costs, and the safety issues mentioned above (Stacy, 2002).

The Idaho Chemical Processing Plant outside of Idaho Falls, Idaho, initially used a hexone process (AEC, 1955). The plant reprocessed aluminum clad fuels from the test reactors at the Idaho site, and other fuels, either zircalloy or steel clad, from other sites.

US efforts at uranium fuel reprocessing culminated with the West Valley plant outside of Buffalo, New York. The plant operated from 1966 to 1972 and processed over 200 tons of commercial and DOE fuel (Runion, 1969; Bailey, 1990). Delange (1985) suggested that the plant was closed mainly due to safety reasons of personnel radiation exposure.

\subsection{Summary of Uranium Fuel Reprocessing Events of Safety Importance}

One of the first events noted was in a technical development facility at Savannah River, code named TNX. This was a test bed facility built in 1951 to perform experiments using mockups of the prototype of the equipment for the TBP process. One 
of the parts tested was a nitric acid evaporator to remove excess nitric acid from the plutonium stream. On January 12, 1953, the TNX evaporator exploded. Investigation revealed that TBP and a kerosene-like diluent, which were immiscible in the aqueous acid, had nonetheless transferred into the evaporator and then chemically reacted with the materials in solution, causing the explosion. This was a matter of concern since it could also occur in production units. The evaporators were removed from the design in favor of an ion-exchange process where cation resins bonded with plutonium (Reed, 2002). The sections below describe some events that have occurred at reprocessing facilities.

6.2.1. Hanford Works. The Pacific Northwest National Laboratory's library has a number of declassified reports from the 1950's, 1960's, and later available for download. This section discusses a few representative events. Parker (1951) discussed I131 uptake in a worker's thyroid gland and that the I-131 emissions were exceeding desired levels at the separations plant. I-131 vegetation contamination in the Walla Walla, Lewiston and Spokane areas was higher than levels that should be maintained in a public area. On December 4, 1951, a laboratory room suffered a fire (HW, 1951). Apparently, nitric acid on rags used for cleaning and decontaminating parts had been boxed for disposal. The rags spontaneously combusted in the waste storage room of a small laboratory building. The security patrol noted smoke from the ventilation stack after the normal work day and heard crackling noises over the night alarm public address system. Firefighters arrived, used water to extinguish the fire. The fire burned for about four hours. Firefighting was hampered by the need for protection from plutonium inhalation. The building air filters were difficult to extinguish and had to be removed to prevent further release of $\mathrm{Pu}-239$ to the atmosphere. The fire damage was not severe, but the contamination spread throughout the building was quite severe. The laboratory building had to be abandoned.

During a process evolution, an acid solution and a caustic solution were improperly mixed (HW, 1953). Metal waste supernatant was being pumped from a holding tank to a blend tank to prepare process feed for the TBP. Approximately 2,800 gallons of $60 \%$ nitric acid was first added to the blending tank. The metal waste addition began, and the agitator for the tank was started. After about 100 minutes, a supervisor noted yellowish ooze coming from the tank cover blocks. As he rushed to the controls to stop the supernatant flow, a geyser of liquid quickly rose about 10 meters in the air for about 30 seconds, and the prevailing wind carried the geyser liquid onto the supervisor and other nearby workers. They were contaminated at $\sim 4,000 \mathrm{cpm}$ and they had stinging sensations from the liquid. The supervisor called to shut the roadway that had been contaminated by the geyser. Investigation revealed that the operator had activated the agitator switch but the agitator had "bumped", it started to operate but had not continued to run. The operator had not paused to verify that the agitator was continuing to run. Trough areas near the blend tank contained up to about 6-inch deep yellowish liquid that read $35 \mathrm{rem} /$ hour at 6 -inches. The spill was cleaned up and operations continued. There were a significant number of personnel contamination reports from maintenance and operations tasks at the Hanford Works. 
The REDOX plant had a contamination event on June 18, 1956. An operator was in the control room for the plutonium concentration facility when a continuous survey meter began to 'break down', that is, to saturate counts at its given setting. The operator investigated and found the meter to be working correctly, the control room had become contaminated. The control room surfaces were contaminated to greater than 7 million disintegrations per minute, off the scale of the instrument. Two process solution (highly concentrated acidic plutonium product) spills were found on the floor behind the control panel. The solution gained entry to the control room by an instrument air line. The instrument air line operated a flow control valve in the process transfer line from the final product concentrator tank to a receiver vessel. When air pressure was relieved from the flow control valve, the air was intended to bleed harmlessly into the control room. The flow control valve stem had a bellows to protect it, but the bellows had failed and process solution had, over time, collected in the valve superstructure. The bleed hole in the valve superstructure still had the manufacturer's dust plug in place. Over time, with no other pathway, the process solution backed up into the air line and out of the vent in the control room. The operator who noted the survey meter "break down" was contaminated on all skin surfaces to over 40,000 dpm. Nasal smears read 30,000 dpm and all of his clothing was contaminated. A rough estimate was that only about $350 \mathrm{~cm}^{3}$ was spilled in the control room, and that was in the $\$ 2-2.5 \mathrm{k}$ cost range.

In the PUREX plant, an event report discussed a heat exchanger failure (Walker, 1961). The acid waste concentrator used a heat exchanger to help condense acid. The heat exchanger had to be taken out of service after only 18 months of operation (planned life was two years, longer if the unit was still operating well) because it had failed. Tests showed that its corrosion resistance was good. The failure was caused by improperly placed weld bead at several tube to tubesheet welds. The welder had laid bead by hand and apparently had deviated by as much as 50 mils $(1.27 \mathrm{~mm})$. The tube wall thickness was affected by the weld placement and this led to premature failure of the tube bundle. The investigators also noted that some tubes had been plugged with solid material and other tubes had solid films, which would have reduced the effective heat transfer.

Backman (1965) discussed airborne releases from Hanford. The PUREX plant stacked 62 curies of I-131 over a three day time period beginning on September 3, 1963. Several "short cooled" fuel elements were placed in the dissolver and significant I-131 was released. On November 6,1963 , resin in a plutonium extraction column caught fire. The fire spread plutonium contamination throughout the building and some outside of the building.

Raab (1970) discussed the silver reactors used to react iodine from the Hanford stack effluents. The system worked well, except for two instances. In the first event, in February 1958, a silver reactor had been flushed with ammonium hydroxide and then water to remove a plug of silver compounds that had accumulated after repeated regenerations. The ammonia compound allowed a rapid exothermic reaction (Irish, 1958). Since that time, plugged silver reactors have been flushed with sodium thiosulfate. The second event was also in 1958 when operators noted that after processing ammonia laden off-gas, the silver reactors would experience exothermic 
reactions that would result in increased outlet temperatures. The plant piping was changed to keep ammonia from the silver reactors, to preclude the possibility of exothermic reactions.

Other events have also occurred at Hanford. In 1976, an ion exchange column suffered a chemical reaction and explosion. A worker was in front of the glovebox that housed the column at the time of the explosion. The worker was injured by glass from the glovebox's shattered window, and the worker received Americium-241 contamination as well (McMurray, 1983). The americium had been collected on the ion exchange resin before the explosion and was dispersed throughout the room in the course of the explosion.

McLaughlin (2000) described a Hanford event in his noted report on criticalities. On April 7, 1962, a plutonium solution reached criticality in a transfer vessel. The total excursion yield was $8 \mathrm{E}+17$ fissions from the vessel. The vessel was allowed to be overfilled with high concentration plutonium solution. The initial fission spike was $1 \mathrm{E}+16$ fissions, and the tank remained supercritical for about 37.5 hours. The plutonium waste recovery facility (Recuplex) was a pilot plant and it was closed after the event (Brown, 1989). Of the twenty-two persons in the building at the time of the event, three received high doses $(110,43$, and 19 rem).

6.2.2 Savannah River Site. A few events were found regarding incidents in the Savannah River reprocessing operations. In both the 1953 TNX event discussed above and in another event on February 12, 1975, there was a 'red oil' explosion in the Thermal Denitrator at the reprocessing plant (McKibbon, 1976). The cause was attributed to the exothermic reaction between TBP and uranyl nitrate. Above $150 \mathrm{C}$, the reaction can become vigorous and result in a thermal runaway event. In general, this type of reaction is referred to as a "red oil"reaction (James, 1991; Gordon, 1994; Robinson, 2003). The name was given to such reactions due to the red colored residue found after such events. Usually TBP and kerosene, the organic material, when mixed with nitric acid or uranyl nitrate, the nitrate material, will react to evolve heat and noncondensable gases. James stated that simply adding a high quantity of organic material alone is not sufficient to result in a thermal runaway. Only the gross mass ingress combined with a failure of the cooling water to the vessel can result in a thermal runaway event.

In initial operations in the 1950's, the PUREX solvent appeared to be degrading and as it degraded it tended to carry radioactives along the solvent stream. The solvent should have chemically resisted entraining any radioactive waste products. Initially, the staff believed that the TBP was partially decomposing to dibutyl phosphate, but testing showed that the kerosene they initially used, called ultrasene, was decomposing and carrying radioactives. They switched to a more stable hydrocarbon, adakene, and this ended most of the solvent degradation troubles (Bebbington, 1990).

An important event occurred in 1960. On September 13, 1960, a valve corridor was highly contaminated by leaking coolant water (Bebbington, 1960). The coolant 
water had become contaminated by high activity waste from the PUREX process, and then the water had leaked through a defective waste evaporator reboiler. Approximately 5,000 Curies was released with the water. Most of the released radioactivity was contained in the building and was flushed to the waste handling facilities. Minor amounts of liquid were released to the seepage basins outside the building. A series of operating errors and miscommunications allowed the initial leakage water to flow back through open valves on steam traps and then out into the corridor. The corridor was flooded with water, and the contaminated water flowed down a stairwell and spread widely throughout normally nonradioactive sections of the building. Radiation readings as high as $400 \mathrm{rad} /$ hour at $30 \mathrm{~cm}$ were measured after the incident. Cleanup was costly and time consuming (Bebbington, 1990). Water flood amounts were not given, but the valve corridor was over $200 \mathrm{~m}$ in length, and the water had to be several $\mathrm{cm}$ deep to flow from the corridor to other areas, so the leak had to be on the order of thousand gallons.

Another issue that Savannah River faced was the same as other chemical plants the process equipment in the separations areas were susceptible to deterioration and failure due to wear and corrosion, and sometimes due to obsolescence (Bebbington, 1990). Hence, the plant was replacing equipment more often than power plants replace equipment, and decontamination cells were needed to decontaminate the removed parts. The canyon cranes presented many maintenance problems. Repairs were hands-on, after the crane was decontaminated as much as possible. In the late 1980's, remote controlled cranes were installed (Bebbington, 1990).

6.2.3 Idaho Chemical Processing Plant. The Idaho Chemical Processing Plant (ICPP) began operations in February 1953 with a processing run on some Hanford targets, called slugs. The ICPP processed mainly aluminum clad fuels for the test reactors at the Idaho site, as well as some academic research reactors, a few foreign reactors, and some naval reactors (Stacy, 2000). The plant recovered over $31,000 \mathrm{~kg}$ of highly enriched uranium and other by products over its life (Knecht, 1997). Accepting various types and enrichments of fuel was a challenge, and the variety sometimes led to unfortunate events.

Searching the DOE Occurrence Reporting and Processing System for ICPP events returned $\sim 600$ events in the past 14 years. Many of these events were personnel anticontamination clothing or skin contamination events, and a number of false fire alarms (as well as false criticality, security, and evacuation alarms) were included in the 600 events. There were several power outage and voltage dip events, and a number of personnel safety issues, including lockout-tagout deficiencies, chemical overexposure, radiation overexposure, procedure violations, and industrial injuries. There was a lightning strike at the facility in June 1998, but there was little damage after alarm systems were returned to normal. Several small fires were reported, in electrical distribution and other equipment, and two small fires with kerosene in the calciner apparatus. Other events included wrong casks and wrong fuel moved or stored, environmental contamination by chemicals (motor oil, diesel fuel, etc.), equipment failures, a few dropped items, and a bomb threat hoax. An ICPP worker was killed in an 
industrial accident when he was struck by a forklift truck in May 1991 (DOE, 1992). These events are tragic and nonetheless endemic to many types of industrial facilities.

The ICPP released 7 million Curies of airborne radioactivity between 1953 1974. Most of the radionuclides released were short-lived; a notable exception is $\mathrm{Kr}-85$ (half-life of $\sim 10.7$ years). In 1975, the Atmospheric Protection System, an air filtering system, was installed. This system greatly reduced the radionuclide releases (Till, 2002). The first ten years of ICPP operations gave the largest releases, with a few years over 1 million Curies. The latter decades of operation produced much smaller releases.

On February 9, 1991, the plant experienced a small explosion that ruptured a 6inch diameter borosilicate glass vessel during dissolving operations to retrieve $1.9-\mathrm{kg}$ of highly enriched, unirradiated uranium fuel from a scrap fuel can of predominantly uranium-zirconium. The uranium was contaminated with thorium, plutonium, and other nuclides. The dissolver vessel was set up within a walk-in confinement hood, but in the course of the explosion some of the 4 liters of hot nitric acid and uranium was splattered onto the three operations personnel in the area. They were not injured by the acid, or by glass shards, but the three operators and one emergency response worker were alpha contaminated; the contamination was not significant. The second dissolver, next to the failed unit, was intact and there was no damage to other equipment. Evidence suggested that a reaction of epsilon phase $\mathrm{U}-\mathrm{Zr}_{3}$ alloy and nitric acid $\left(\mathrm{NHO}_{3}\right)$ occurred (DOE, 1992a). Durant reported some similar events, most of low consequence, at Savannah River (Durant, 1991).

There were three noted criticality events at the plant. The first criticality occurred on October 16, 1959, at 0250 hours. Concentrated uranyl nitrate was accidentally transferred from a geometrically safe storage bank to a waste collection tank. Air sparging was believed to be the cause of the unwanted transfer. There were twenty-one personnel on duty at the time, only seven received notable radiation doses, the highest individual dose being $8 \mathrm{rem}$ (Ginkel, 1960; McLaughlin, 2000). The second event occurred on January 25, 1961 (Paulus, 1961; McLaughlin, 2000). A solution of enriched uranyl nitrate was accidentally lifted from a geometrically safe section of an evaporator to the upper, vapor-disengager section that was not geometrically safe. The liquid may have moved upward due to a burst of air being introduced into the bottom of the evaporator as operators tried to clear a line. An energy excursion of $20 \mathrm{MW}$-s occurred $(6 \mathrm{E}+17$ fissions). The highest personnel exposure was $55 \mathrm{mrem}$. The third event occurred on October 17, 1978 (ACI, 1978; NS, 1980; McLaughlin, 2000). By 1978 the ICPP had converted from using hexone to TBP. The first solvent extraction cycle was operating on highly enriched uranium fuel, but the aluminum nitrate feed into a scrubbing column was outside of parameters; the column began to strip uranium rather than scrub. Uranium built up in the column and instrumentation to warn operators of low out-ofspecification aluminum nitrate was inoperative. The operators also did not follow all procedures for sampling the feed. Consequently, the uranium reached about $22.2 \mathrm{~g}$ of $82 \%$ U-235 in the column and attained criticality. After the event was recognized, a combination of diluting and dumping solution from the column reestablished subcriticality. No one was injured in the event. 
6.2.4 United Nuclear Corporation. The United Nuclear Corporation operated a fuel recovery plant near Wood River Junction, Rhode Island in the 1960's. The plant was to recover enriched uranium from scrap material left over from the production of fuel elements. Scrap was shipped to the plant as uranyl nitrate in 55-gallon drums. The uranyl nitrate was purified and concentrated by using TBP with kerosene as a wash. Then trichloroethane was used in stripping columns to remove kerosene. On July 24, 1964, at about 6:00 pm, a technician was working in the plant along with the shift supervisor, three other technicians, and a security guard. The technician was working with a "makeup" tank of sodium carbonate that was used to remove uranium from trichloroethane used the stripping columns. The plant had just started operation in March 1964, and typical of new plants, the trichloroethane was allowing kerosene carryover and was retaining uranium; these unwanted features reduced the useful life of the trichloroethane to $\sim 1$ week. The original procedure was to manually shake the 11-liter bottles of trichloroethane solution with sodium carbonate solution added, to recover the 400 to $800 \mathrm{ppm}$ uranium. The sodium carbonate solution wash was performed to remove uranium before discarding the trichloroethane. The technician had gotten permission to use a makeup tank instead of manually shaking the 11-liter bottle. The sodium carbonate makeup tank was constructed of stainless steel and was not designed to be a 'criticalitysafe' tank. The trichloroethane operation had been in progress for over a week without incident. On July 23 , the plant evaporator had plugged with uranium nitrate crystals. It was steam cleaned to removed the crystals and the resulting concentrated solution was stored in 11-liter bottles. The technician mistook the contents of one of the steamcleaning 11-liter polyethylene bottles for mildly contaminated trichloroethane, even though the bottle was clearly marked as concentrated liquor from the evaporator (the label was found near the transport cart for the 11-liter bottle). As had been performed for over a week, the technician turned the tall cylindrical bottle to pour the contents into the makeup tank of 41 liters of 0.54 molar sodium carbonate solution; the bottle actually contained 11 liters of uranyl nitrate with a concentration of 256 grams of uranium (which was $93 \%$ enriched in U-235) per liter. An electric stirrer was operating in the tank as well. When ten of the eleven liters was poured into the tank, the technician witnessed a blue-white flash and physical ejection of $\sim 20 \%$ of the liquid from the tank, some of which impinged on the ceiling and some splashed on the technician (Auxier, 1965; Nakache, 1964; McLaughlin, 2000). The criticality was estimated to be approximately $1 \mathrm{E}+17$ fissions. The technician received an estimated total dose of 10,000 rads of neutron-gamma exposure, as estimated from blood sodium activation; this is a supralethal dose. He perished 49 hours later from radiation induced physical deterioration. The plant superintendent and the supervisor made entries into the room to secure the equipment to avoid additional criticalities. The plant superintendent turned off the electric stirrer to the makeup tank,; after the stirrer vortex dissipated another criticality occurred that yielded 2 to $3 \mathrm{E}+16$ fissions at 15 feet from the tank. The two men were farther away $(\sim 12$ feet versus $<2$ feet) from the tank than the technician had been and were shielded by the room's concrete block walls when the second excursion occurred. After the second excursion, there was enough settling in the tank that the uranium was no longer in a critical concentration with the aqueous sodium carbonate solution. Their exposure during mitigation and amelioration activities was estimated to be on the order 
of 100 and 60 rems based on film badges and silver activation in the dimes and silver dollar in the pocket of one of the men. Others in the facility received less than $1.25 \mathrm{rem}$ in this event. 


\section{Chapter 6 References}

ACI, 1978. Recovery of ICPP from Criticality Event of October 17, 1978, Part I - Basic Technical Data, ACI-362, Allied Chemical Idaho, November 1978.

AEC, 1955. Chemical Processing and Equipment, United States Atomic Energy Commission, McGraw-Hill Book Company, New York, 1955.

Auxier, 1965. J. A. Auxier, "Nuclear Accident at Wood River Junction," Nuclear Safety, 6 (1965) 298-301.

Backman, 1965. G. E. Backman, Summary of Environmental Contamination Incidents at Hanford, 1958-1964, HW-84619, General Electric Hanford Atomic Products Operation, April 12, 1965.

Bailey, 1990. W. J. Bailey, West Valley Facility Spent Fuel Handling, Storage, and Shipping Experience, PNL-7436, Pacific Northwest Laboratory, November 1990.

Bebbington, 1960. W. P. Bebbington, Contamination of the Hot Gang Valve Corridor and First-Level Clean Areas of Building 221-F - September 13, 1960, DPSPU60-11-34, E. I. du Pont de Nemours \& Company, December 1960.

Bebbington, 1990. W. P. Bebbington, History of Du Pont at the Savannah River Plant, E. I. du Pont de Nemours and Company, ISBN 0-934870-27-6, 1990.

Benedict, 1957. M. Benedict and T. H. Pigford, Nuclear Chemical Engineering, McGraw-Hill Book Company, New York, 1957, chapter 8.

Brown, 1989. C. L. Brown, The April 1962 Criticality Event in the Recuplex Facility, WHC-SA-0718, Westinghouse Hanford Company, September 1989.

Delange, 1985. M. Delange, "Operating Experience with Reprocessing Plants," Atomwirtschaft-Atomtechnik, 30 (January 1985) 24-28.

DOE, 1991. Rupture of Dissolver No. 1 in the Hot Chemistry Lab, Occurrence Report ID-WINC-ICPP-1991-0026, Department of Energy, February 11, 1991.

DOE, 1992. "Worker Safety Compromised When Operating Forklifts in Reverse," DOE Environment, Safety and Health Bulletin, DOE/EH-255, Issue 92-3, US Department of Energy, June 1992.

DOE, 1992a. Explosion Hazards of Uranium-Zirconium Alloys, DOE/NS-0008, ONS Safety Notice Issue No. 92-03, US Department of Energy, August 1992. 
DOE, 2003. Hanford Site Historic District, History of the Plutonium Production Facilities 1943-1990, DOE/RL-97-1047, ISBN 1-57477-133-7, Battelle Press, Columbus, Ohio, 2003.

Durant, 1991. W. S. Durant, D. K. Craig, M. J. Vitacco, J. A. McCormick, Adverse Experiences with Nitric Acid at the Savannah River Site, WSRC-TR-91-22, revision 1, Westinghouse Savannah River Company, June 1991.

Ginkel, 1960. W. L. Ginkel et al., Nuclear Incident a the Idaho Chemical Processing Plant on October 16, 1959, IDO-10035, Phillips Petroleum Company, February 15,1960 .

Gordon, 1994. P. L. Gordon, C. O’Dell, and J. G. Watkin, "Synthesis and energetic content of red oil," Journal of Hazardous Materials, 39 (1994) 87-105.

HW, 1951. P-11 Laboratory Fire Investigation, December 4, 1951, HW-22936, Hanford Works, December 7, 1951.

HW, 1953. Manufacturing Department Radiation Incident Investigation, Incident Number 65, HW-28021, Hanford Works, May 11, 1953.

Irish, 1958. E. R. Irish, Separations Plant Silver Reactor Incident, HW-57048, also in Proceedings of the 1958 Atomic Energy Commission and Contractor Safety and Fire Protection Conference, Germantown, Maryland, June 24-25, 1958, report TID-7569, 1958, pages 44-53.

James, 1991. N. J. James and G. T. Sheppard, "Red oil hazards in nuclear fuel reprocessing," Nuclear Engineering and Design, 130 (1991) 59-69.

Knecht, 1997. D. Knecht et al., "Historical Fuel Reprocessing and HLW Management in Idaho," Radwaste Magazine, 4, May 1997, pages 35-47.

McKibbon, 1976. J. M. McKibbon, Explosion and Fire in the Uranium Trioxide Production Facilities at the Savannah River Plant on February 12, 1975, DPSPU 76-11-1, E. I. du Pont de Nemours \& Company, October 1976.

McLaughlin, 2000. T. P. McLaughlin et al., A Review of Criticality Accidents, 2000 Revision, LA-13638, Los Alamos National Laboratory, May 2000.

McMurray, 1983. B. J. McMurray, "1976 Hanford Americium Exposure Incident: Accident Description,” Health Physics, 45 (1983) 847-853.

Mottel, 1995. W. J. Mottel, J. F. Long, and D. E. Morrison, Industrial Safety is Good Business, the DuPont Story, John Wiley \& Sons, New York, 1995, chapter 9. 
Nakache, 1964. F. R. Nakache and M. M. Shapiro, The Nuclear Aspects of the Accidental Criticality at Wood River Junction, Rhode Island, July 24, 1964, TID21995, November 12, 1964.

NS, 1980. “ICPP Criticality Event of October 17, 1978," Nuclear Safety, 21 (1980) 648653.

Parker, 1951. H. M. Parker, Health Instrument Divisions Report for Month of June, 1951, HW-21506-E, Hanford Works, July 2, 1951.

Paulus, 1961. R. C. Paulus et al., Nuclear Incident at the Idaho Chemical Processing Plant on January 25, 1961, IDO-10036, Phillips Petroleum Company, June 1, 1961.

Raab, 1970. G. J. Raab and R. E. van der Cook, Operating Experience Using Silver Reactors for Radioiodine Removal in the Hanford PUREX Plant, ARH-SA-67, Atlantic Richfield Hanford Company, June 1970.

Reed, 2002. M B. Reed et al., Savannah River Site at Fifty, US Department of Energy, Washington, DC, ISBN 0-16-067182-5, 2002.

Robinson, 2003. R. N. Robinson et al., Control of Red Oil Explosions in Defense Nuclear Facilities 2003, DNFSB/TECH-33, Defense Nuclear Facilities Safety Board, November 2003.

Runion, 1969. T. C. Runion and W. H. Lewis, "Construction and Operation of the West Valley Reprocessing Plant," Proceedings of the $60^{\text {th }}$ Annual Meeting of the American Institute of Chemical Engineers, Chemical Engineering Progress Symposium Series No. 94, 1969, pages 53-60.

Stacy, 2000. S. M. Stacy, Proving the Principle: A History of the Idaho National Engineering and Environmental Laboratory, 1949-1999, US Government Printing Office, ISBN 0-16-059185-6, 2000.

Till, 2002. J. E. Till et al., Identification and Prioritization of Radionuclide Releases from the Idaho National Engineering and Environmental Laboratory, RAC Report No. 3-CDC Task Order 5-2000-FINAL, Centers for Disease Control, Department of Health and Human Services, October 2002.

Walker, 1961. W. L. Walker, Examination of PUREX F-6 Heat Exchanger Failure, HW68268, General Electric Hanford Atomic Products Operation, January 30, 1961. 


\section{FUEL AND WASTE TRANSPORTATION}

\subsection{Brief History and Description of Fuel and Waste Transportation}

As noted in previous chapters, the uranium was continually being moved from one operation at a given location to the next operation at another location. Uranium is generally moved by two means, truck or rail. Some of the facilities, such as Hanford, Idaho, and Savannah River had private rail lines to allow movement of heavy shielded casks. From the ISL mine, the yellow cake uranium is typically packaged in 55-gallon drums and is moved by truck to the purification and conversion facility. Then the unenriched uranium hexafluoride is moved in large (10 or 14 ton) cylinders, usually by rail, to the gaseous diffusion enrichment plant. Then the enriched uranium hexafluoride is moved in the same type of cylinder to a fuel fabrication facility, usually by rail. The hexafluoride cylinders are overpacked for protection in case of off-normal events. After fuel is fabricated, the fuel elements are shipped in casks to power reactor sites. After the fuel has been used, it is referred to as spent fuel and it is stored at the reactor site. This is called the once-through fuel cycle (Graves, 1979). There has been some fuel shipping for Naval reactors and DOE reactors. SAIC estimated that 2,600 commercial spent fuel shipment have taken place from 1965 to 1991 , both by rail and truck, without radioactive fatalities, injuries, or environmental harm (SAIC, 1991). Shipments on highways must meet Department of Transportation and Nuclear Regulatory Commission regulations.

\subsection{Summary of Off-Normal Events in Uranium Fuel and Waste Transportation}

There are many shipments of nuclear materials every year in the US. In the six month time period from October 1961 to March 1962, there were over 24,000 shipments. Nearly half were in type A packages, and over 10,000 were in type B packages, and the remainder were shipments that exceeded the Curie limits for type B packages (Shappert, 1963). There are also many shipment of nuclear waste. Shappert presented data that from 1949 to 1956, there were fifteen accident events with radioactive material; of those, six did not release any radioactive material, two had package breach but no release, three events released material to the ground, one accident event resulted in aerial dispersal, and one event resulted in released material entering a waterway. Shappert also presented data on the 1957-1961 time frame, citing 47 accident events. Of those, 29 were accidents with no material release, seven events had package breach but no release, another seven events had material release that was confined to the vehicle, three events of release to the ground, and one event of aerial dispersal. More recent data (Emerson, 1985) cited 811 transportation incidents from 1971-1981, but only 108 of the incidents were vehicle accidents. In 1981, there were only eight radioactive material highway accidents in the US, and only two of those resulted in releases.

Some other event case histories are briefly described here. An operations report (AEC, 1975) has listed a number of inconsequential accidents with trucks and trains, and a few events of interest. On July 23, 1964, near the Fernald plant, a freight car door broke open during railcar switching operations and two drums fell out of the car. One 
drum breached, and the contents were cleaned up. In another event on March 31, 1971, a train was en route from Hanford to Fernald. One railcar was loaded with 74 containers of uranium fuel elements. The car experienced a fire due to a dragging brake shoe that overheated. Seven containers were affected by the fire, but none breached.

Chandler (1972) discussed an event where a casked spent fuel element from the Peach Bottom high temperature gas-cooled reactor was involved in a traffic accident. The truck was carrying only the one element; it was en route to Oak Ridge National Laboratory. The cask weighed about 23 tons empty, and measured about $6 \mathrm{~m}$ in length and $0.6 \mathrm{~m}$ in diameter. The cask was well cradled and bolted rigidly to the truck trailer. About 3 miles north of Clinton, Tennessee, an oncoming tractor-trailer veered toward the spent fuel truck as both were rounding a tight curve in the road. Witnesses stated that the cask vehicle was traveling at appropriate speed for the curve and that the oncoming truck was "crowding" the spent fuel truck. The spent fuel truck driver steered toward the shoulder to avoid a head-on collision with the oncoming truck. The spent fuel truck driver lost control of his truck while it was on the shoulder of the highway. His vehicle overturned and the cask dug into the soft soil about $1 \mathrm{~m}$ deep, then skidded for about 28 $\mathrm{m}$. Then the trailer and cab broke away from the cask and continued on for another $15 \mathrm{~m}$ before coming to a rest. Investigators believed that the tie down cables parted under the forces developed during the accident, but the cask was not breached nor significantly damaged in the accident. The truck driver was killed; this was the only human injury in the accident.

Another highway accident event occurred in 1991. On December 16, 1991, at about 3:15 am, a truck hauling unirradiated reactor fuel from the GE fuel fabrication facility in Wilmington, North Carolina to the Vermont Yankee power plant encountered an allegedly intoxicated motorist in a passenger car at Springfield, Massachusetts (Carlson, 1992). The passenger car was traveling southbound in the northbound lanes. Weather was not a factor; the night was clear, the road was dry, and there was little other traffic. The car and truck were both using the same lane. The car struck the truck, apparently impacting the trailer rather than head-on with the tractor, because the truck driver had veered left in an attempt to avoid collision while the car continued in the lane. The truck then struck a small curb and guardrail at the side of the highway, then the truck continued across the road and impacted the barrier there. In these collisions, the truck lost the left front wheel, the hood and fenders from the cab, and the front axle. In the final impact with the barrier, at least one of the truck's fuel tanks ruptured. A fire ignited from either engine fluids or from diesel fuel, and all these fluids burned. The fire spread to engulf the entire tractor and burned vigorously for over three-fourths of an hour. After about an hour of tractor fire, the tarpaulin over the fuel containers ignited, then the wooden outer containers ignited. The fire then spread to the wood planks in the trailer bed, then the tires. Evaluation of the post-fire evidence suggested that the fire temperature had reached 1,800 F. Some containers fell from the truck as the bed burned; therefore, some containers were exposed to fire for perhaps an hour while other containers were exposed to fire for two hours. During the course of the fire, as well as the combustibles in the truck, even some asphalt from the roadway burned. There was no release of radioactivity from the containers in this event. The fuel elements inside the 
containers did suffer thermal damage; they deformed to the shape of the inner containers, with calculated peak temperatures of $1,500 \mathrm{~F}$ reached in the fuel rods. The fuel remained in a safe geometry and criticality was not possible in this accident. The truck driver and co-driver had only minor injuries. The car driver suffered non-fatal collision injuries.

A rail accident was documented by Devries (1988). In February 1982, a locomotive operated by a commercial railroad company impacted three railroad cars that were in the process of being uncoupled from the train. The locomotive had brought the railroad cars from the Mound plant in Ohio and the Rocky Flats plant in Colorado, the waste being transported was to be stored at the Radioactive Waste Management Complex (RWMC) at the INEL. At about 3:20 am on February 24, the caboose and other cars not bound for the RWMC were released to stand on the track. Then the locomotive moved forward, pulling only the three railcars. The locomotive uncoupled from the three cars after the cars began moving, and a spur line switch was thrown after the locomotive passed. This was a routine action performed to route the three cars toward the RWMC. The three cars traveled down the spur line toward the RWMC as planned. Then the locomotive stopped and backed up so that it could also travel down the spur line to RWMC. Because the RWMC had a security fence, the three rail cars were manually slowed as they approached the facility. When the locomotive came around a bend in the spur line, the engineer realized that the three cars were there, stopped. The locomotive could not brake quickly enough to avoid a collision. Several railroad workers jumped from the cars and the locomotive before the impact, they suffered only minor abrasions. The three cars rolled about 245 feet before coming to a stop. They did not strike the security fence. The locomotive had some damage, and the car that was struck had some damage. The middle car had no cargo damage. The waste boxes in the car closest to the locomotive were not damaged. Two cargo containers, filled with waste drums, in the last car showed slight damage - one had doors bulged and another had doors sprung slightly ajar. Some waste drums were dented but none were breached. There were no radioactive releases from this event. Damaged drums were overpacked into 83 gallon drums for storage at RWMC.

Eide (2003) has reviewed accident rates for truck and rail shipments. The basic value for a truck accident on the US interstate highway system is $3.2 \mathrm{E}-07 / \mathrm{km}$. For rail cars, the representative national value for accident probability is $6.1 \mathrm{E}-08 /$ railcar-km. Eide also reported that the fatality rate is 0.028 fatalities per truck accident on interstate highways, and 0.37 fatalities per rail accident.

Since highway accidents involving radioactive materials are low frequency events, and since casks are robust structures that are not often breached during the course of accident events, the hazard from accident-free shipment has been assessed. Weiner (1991; Weiner, 1991a) has examined the 1.6 million radioactive material yearly highway shipments (1.1 million are medical isotopes, only 10,000 are fuel cycle shipments each year) and calculated that the maximum public dose per shipment is $27 \mathrm{pSv}$ (2.7 nanorems). While activists point out that transportation of radioactive materials affects tens of thousands of people, and these shipments cross many states, operating 
experiences show that accidents have been rare, and releases are rare given an accident. Most of the time the public is being affected only by vanishingly small doses. 


\section{Chapter 7 References}

AEC, 1975. Operational Accidents and Radiation Experience within the United States Atomic Energy Commission, 1943-1975, WASH-1192, Us Atomic Energy Commission, Fall 1975.

Carlson, 1992. R. W. Carlson and L. E. Fischer, A Highway Accident Involving Unirradiated Nuclear Fuel in Springfield, Massachusetts, on December 16, 1991, NUREG/CR-5892, UCRL-ID-110638, Lawrence Livermore National Laboratory, June 1992.

Chandler, 1972. J. M. Chandler, The Peach Bottom Spent Fuel Element Shipping Cask Accident, December 8, 1971, ORNL-TM-3844, Oak Ridge National Laboratory, July 1972.

Devries, 1988. R. L. Devries and E. E. Bybee, Railroad Accident at RWMC Involving Railroad Cars Transporting Radioactive Material, WM-PD-88-001, EG\&G Idaho, Inc., March 1988.

Eide, 2003. S. A. Eide and T. E. Wierman, Environment, Safety, and Health Risk Assessment Program (ESHRAP), INEEL/EXT-02-00181, Idaho National Engineering and Environmental Laboratory, December 2003.

Emerson, 1985. E. L. Emerson and J. D. McClure, Radioactive Material (RAM) Accident/Incident Data Analysis Program, NUREG/CR-3611, SAND82-2156, Sandia National Laboratories, March 1985.

Graves, 1979. H. W. Graves, Jr., Nuclear Fuel Management, John Wiley \& Sons, Inc., New York, 1979, chapter 2.

SAIC, 1991. Historical Overview of Domestic Spent Fuel Shipments - Update, ORNL/Sub-88-997962/1, Science Applications International Corporation, July 1991.

Shappert, 1963. L. B. Shappert, "Accidents in Shipping Radioactive Material," Nuclear Safety, 5 (1963) 123-127.

Weiner, 1991. R. F. Weiner, P. A. LaPlante, and J. P. Hageman, “Approach to assessing the impacts of incident-free transportation of radioactive materials. I. Air Transportation,” Risk Analysis, 11 (1991) 655-660.

Weiner, 1991. R. F. Weiner, P. A. LaPlante, and J. P. Hageman, “Approach to assessing the impacts of incident-free transportation of radioactive materials. II. Highway Transportation,” Risk Analysis, 11 (1991) 661-666. 


\section{URANIUM FUEL AND WASTE STORAGE}

The storage of uranium fuel or uranium waste is the final step in the fuel cycle. Since there is no commercial spent fuel reprocessing, and there is no permanent repository for commercial spent nuclear fuel, the uranium spent fuel from commercial power reactors is typically stored at the site where it was used.

\subsection{Brief History and Description of Uranium Fuel and Waste Storage}

US electric utilities typically store their spent fuel at reactor sites. Recently used fuel is kept in water-filled spent fuel pools. Some fuel that has decayed for long times ( $\sim$ decades) can be stored in casks without any water cooling. These casks are referred to as dry casks, since many short-term shipping casks are filled with water for its benefits of cooling and extra radiation shielding.

There are also wastes from the fuel cycle. Uranium mill tailings were briefly discussed in Chapter 2. Fuel purification and the fuel reprocessing plants have also generated chemical and radiological wastes. Leventhal (1989) stated that while much attention had been focused on the effects of radiation on workers in the nuclear industry, there were also important industrial hygiene safety concerns with waste disposal. Workers could be exposed to gases, volatiles, particulates and liquids, as well as heat, explosions, spontaneous ignition, and noise.

\subsection{Summary of Off-Normal Events in Uranium Fuel and Waste Storage}

For the purposes of this report, there are two classes of waste storage. The first class is waste stored at fuel cycle facilities, and the second class is spent fuel elements stored at commercial power plants. Some events from each type of storage are briefly described below.

Gerber (1991) has pointed out that two-thirds of all the nuclear waste in the DOE complex is located at Hanford. An issue of safety and environmental concern has been underground waste tanks at Hanford. Underground tanks were first built to take advantage of the shielding that earth can provide. Underground tanks are also less vulnerable to other types of events, such as vehicles colliding with tanks, lightning strikes on tanks, radiant heat from area fires near the tanks, etc. As Hanford was required to increase production in the 1950's, there was a chronic shortage of tank space, so evaporators were built to boil off low level aqueous waste for cribbing (a crib was a wood or concrete walled trench where wastes were poured and then buried) and to reduce the volume of high level wastes.

Backman (1965) described two notable events at the Hanford site. In the first event, on January 8, 1959, a burial box containing Redox processing equipment collapsed during trench backfilling. Contamination spread past the area fence, but not off the Hanford site. Near the area fence the contamination read at 400 counts/minute, and 50 millirads/hour near the burial site. In the other event, on June 10, 1960, some PUREX 
equipment that had been removed from service was also being buried at the site. The burial box had been placed in a trench, but the box walls collapsed during the trench backfilling operation. The contamination spread was severe. Contaminated particles were located as far as three miles from the area fence. Contamination levels were 60 millirads/hour near the burial trench to about 1,000 counts/minute outside the area. Two private vehicles in the PUREX plant parking lot were contaminated; but the contamination did not leave the Hanford boundaries.

Forby (1980) discussed several uranium metal fire events involving scrap uranium that was to be sent by truck or rail from Hanford to the Fernald plant in Ohio. Uranium scraps were produced when manufacturing fuel for the $\mathrm{N}$ reactor at Hanford. The uranium was initially burned in a furnace to reduce the uranium to oxide, but the contamination from burning was high, so the uranium metal scraps (fines, chips and turnings) were encapsulated in concrete. For six years the encapsulation process was performing well. The process involved using metal cans for the concrete forms, and adding the uranium as the concrete was added, then allowing 7-day curing. After curing, the metal cans would be lidded and banded, then crated for shipment. In August 1977, six of ninety-six cans caught fire during the curing process. The August temperatures in a non-air conditioned metal building added to the heat of hydration allowed the uranium to burn in air. After that event, the uranium-concrete was cured under a cold water spray for the seven days. In July 1979, another fire occurred. Wooden crates were on fire. Firefighters applied water, but only the wood extinguished, the metal can contents continued to burn. The crates on pallets were moved out of the warehouse building and met-l-x fire suppressant and sand were applied to the burning uranium. Several of the metal cans broke open, and then uranium would be propelled outward, energetically burning and giving the impression of sparklers used in July $4^{\text {th }}$ celebrations. The fires burned for about nine hours. The contamination was very minor for the severity of the fire, most of the contamination was in the firefighting water that had run off from the warehouse. Investigation revealed that the concreted uranium cans had been removed from water spray curing 4 days early, so when lidded and encased in crates in a hot room, the uranium caught fire. One can fire was enough to ignite other can fires. Tests were conducted to determine the sensitivity of the concreted cans to heat since these were being shipped to Ohio. A temperature of $63 \mathrm{C}$ over more than three days seemed to be sufficient to cause a uranium fire. Testing showed that reduced water content concrete, better cooling during curing, and longer curing time could eliminate uranium autoignitions.

At the Savannah River Site, there are also low level burial grounds for wastes generated from reprocessing nuclear fuels. Cornman (1977) discussed the approaches to burial and a few events that had occurred. Earthen trench burial for low level waste and above ground storage for transuranic materials have been the principal modes of storage at Savannah River. In the previous twenty years, there had been only a few incidents. The typical wastes in the burial ground are contaminated equipment such as failed tanks, pipes, and process equipment, reactor and reactor fuel hardware from the Savannah River reactors, spent lithium-aluminum targets (after tritium extraction), laboratory and operations wastes such as clothing, small equipment, and analytical waste, and spent de- 
ionizer resins. There is also a storage facility for spent organic solvent; about 150,000 gallons of solvent are stored in underground storage tanks. Any incidents with releases or contamination usually were with fractional Curies of activity and only affected a few thousand square feet. The types of incidents were equipment burial events, where poorly wrapped items for burial allowed a particulate release. Any contaminated ground would generally be bulldozed into the burial trench. Such events have been rare since 1969 because more care is taken in wrapping and preparing materials for burial, and burial operations are now performed only during favorable weather conditions. There had been eight minor waste fires in the twenty years discussed by Cornman. Seven fires were in low level waste trenches and were of undetermined origin. The most likely explanation was spontaneous combustion. All of the fires were extinguished by either smothering with backfill soil or by applying water. There were nine organic liquid spills; all occurred either in transporting solvent to burial or in transferring solvent from the tank truck to storage tanks. The overall incident frequency has decreased from five per year to two per year or less.

Commercial power plants store waste either in spent fuel pools, whose water cleanliness, temperature, and level are monitored, or in dry casks. Ibarra (1996) reviewed spent fuel pool accident scenarios and operating experience. That study found several conclusions. The loss of spent fuel pool coolant inventory of greater than $30 \mathrm{~cm}$ depth was about 1 per 100 reactor-years. Loss of spent fuel pool water cooling with a temperature increase greater than $20 \mathrm{~F}$ has occurred with a rate of 3 per 1,000 reactoryears. The highest temperature reached in any thermal excursion of the pool water was $140 \mathrm{~F}$; there were no reported approaches to boiling in the data reviewed. Human performance is the most important factor for both loss of spent fuel cooling (incorrect valve or electrical power alignments, incorrectly isolating air to pneumatic seals, etc.) and for recovery actions. Often, the spent fuel pool is not regarded as a serious issue, even though several cores may reside there. The sheer volume of water in the pool indicates that any transient which can occur would be slow acting, giving operators much time to assess and act on the initiator. In a counterpoint, as refueling outages grow shorter, and partial cores are transferred from the reactor to the spent fuel pool faster. This shortened time frame results in significant heat loads to the pool. The potential to reach near boiling conditions is within 5 to 10 hours if active cooling is lost. Ibarra called for improved procedures and training, and improvement in instrumentation and power supplies for spent fuel pool equipment.

Dry cask storage has been approached by the electric utilities because the spent fuel pools at some utilities have reached capacity (Kane, 1997). The basic dry cask approach is to store from 7 to 24 fuel assemblies in a holder basket, then the basket is placed inside a stainless steel container. The container is loaded with fuel elements in a spent fuel pool, then the lid is welded on. Next, the container ports are opened to drain water, dry by vacuum, and fill with helium. Then the container is sealed and placed inside a concrete, ventilated cask for above ground storage (Wilson, 1996). An accident occurred during a loading activity on May 28, 1996 (NRC, 1996). On that date, a utility was loading fuel elements into a stainless steel container in preparation moving those elements to dry storage. Some water had been drained, as is the practice, to allow 
welding the lid in place. Hydrogen gas had formed and the welding process ignited the gas in the container headspace. The stainless steel container lid (weighing 2,898 kg) was moved by the deflagration pressure and canted about $7.6 \mathrm{~cm}$. No one was injured or contaminated in the event. The basket, container, and the fuel elements were not damaged by the explosion. The utility and the NRC Augmented Investigation Team agreed that the hydrogen was generated from the pool water inside the stainless steel container. The basket that holds the fuel elements had been coated to prevent corrosion with the borated pool water. The basket coating was 'carbozinc', which in theory was a prudent design provision for corrosion prevention. Unfortunately, the acidic borated water reacted with the zinc in the coating, creating zinc oxide, zinc hydroxide, and hydrogen. Macfarlane (2001) noted that dry cask storage in the US has had a good safety record, since inception in 1985 there have not been any events where radiation was released. There were some other cask events noted by Macfarlane, two other hydrogen generation events at two other utilities, and some events of defective welds and cracked seals were detected in some casks at two utilities.

Macfarlane (2001) noted that the safety issues for dry casks are: casks maintaining integrity over their 20-year licensed lifetimes, if the presently designed casks can accommodate spent fuel at higher burnups than past fuel (i.e., over 45,000 MWdays/ton versus less than $30 \mathrm{MW}$-days/ton), and what provisions must be on hand if a cask leaks. For example, if a utility shuts down a reactor, safely transfers all the spent fuel to low-cost dry storage, and then a cask leaks (i.e., loses helium), some provision must be retained at the site so that the fuel elements be transferred to a new cask. The NRC is considering these issues. 


\section{Chapter 8 References}

Backman, 1965. G. E. Backman, Summary of Environmental Contamination Incidents at Hanford, 1958-1964, HW-84619, General Electric Hanford Atomic Products Operation, April, 1965.

Cornman, 1977. W. R. Cornman, "Improvement in Operating Incident Experience at the Savannah River Burial Ground," DP-MS-77-19, CONF-770512011, Proceedings of the Symposium on Management of Low Level Radioactive Waste, Atlanta, Georgia, May 23, 1977.

Forby, 1980. L. P. Forby, Auto-Ignition of Concreted Uranium Scrap, UNI-SA-75, CONF-800436-1, UNC Nuclear Industries, April 10, 1980.

Gerber, 1991. M. S. Gerber, Historical Genesis of Hanford Site Wastes, WHC-SA-1224, Westinghouse Hanford Company, September 1991.

Ibarra, 1996. J. G. Ibarra et al., “Assessment of Spent Fuel Cooling,” Nuclear Safety, 37 (1996) 237-255.

Kane, 1997. W. F. Kane and P. L. Eng, "Challenges in Dry Cask Storage of Spent Fuel in the US," Proceedings of the $5^{\text {th }}$ International Conference on Nuclear Engineering, May 26-30, 1997, Nice, France, paper 2282.

Leventhal, 1989. L. Leventhal and G. Caesar, Jr., "Low-Level Radioactive Waste Disposal Needs Industrial Hygiene Expertise," Occupational Health and Safety, November 1989, pages 36-38.

Macfarlane, 2001. A. Macfarlane, "Interim Storage of Spent Fuel in the United States," Annual Review of Energy and Environment, 26 (2001) 201-235.

NRC, 1996. Chemical, Galvanic, or Other Reactions in Spent Fuel Storage and Transportation Casks, NRC Bulletin 96-04, US Nuclear Regulatory Commission, July 5, 1996. 
Appendix A. Trip Notes from a Visit to a Fuel Fabrication Facility 


\section{Westinghouse Savannah River Company Aiken, SC 29808}

March 30, 2004

TO: KEMAL PASAMEHMETOGLU, LANL, TA-53

FROM: $\quad$ STEVE SHEETZ

\section{FACILITY TOUR OF BNFL/WESTINGHOUSE COLUMBIA NUCLEAR FUELS PLANT}

Several AFCI participants toured the Columbia Nuclear Fuel manufacturing facility on March 5, 2004. This helped provide baseline knowledge of fuel manufacturing process and its facilities.

\section{AFCI Participants}

Mitch Meyer, ANL

Steve Long, LANL

Brent Boore, WSRC

Dave McGuire, WSRC

Steve Sheetz, WSRC

Dave Harris, Manager Fuel Rod Operations, was the host for our three-hour tour through the facility.

The Columbia Fuels Plant located in Columbia, South Carolina makes uranium oxide (UOX) fuels for both PWR's and BWR's. Average annual production is about 1200 tonnes of fuel with a peak capacity of approximately 1350 tonnes. Total staffing is approximately 1100 personnel with 600-700 in operations and maintenance.

The basic production operations are:

- Rod receipt and preparation

- Pellet manufacture, fuel rod loading

- Rod inspection 
- Fuel assembly area

- Final inspection and shipping

\section{Rod Receipt and Preparation}

When the rods are received from the suppliers, no receipt inspection is conducted. The rods are produced to NQA-1 standards, and the additional work is not required. Each rod has a unique laser engraved barcode so it can be tracked throughout the process. (Note: The barcode is also used for material accountability - missing rods are reportable to NRC.) The rods are fed onto a stepping conveyor system that uses a "rope cleaner" to swab the weld area, presses on the bottom cap and the caps are then automatically TIG welded. The rods are then ready to be loaded with pellets. Latex gloves are worn by operations personnel throughout this and all other processes to minimize introduction of oils and moisture.

\section{Pellet Manufacturing}

The pellet manufacturing area consists of 5 parallel and independent operating lines. Each consists of a uranium hexafluoride evaporator, chemical converter, a green pellet press, a sintering furnace, and a grinding station followed an inspection step.

Low-enriched uranium hexafluoride, the starting material for the chemical conversion process, is vaporized. This gaseous uranium hexafluoride is then absorbed by pure water to produce uranyl fluoride solution. Ammonium hydroxide is added to this solution and ADU (ammonium diuranate) is precipitated. Further, through processes of dewatering, drying, calcination / reduction, and milling, uranium dioxide powder is manufactured from ADU. The powder is collected into 2-gallon cylindrical plastic tubs - with the lids taped shut - and is bar-coded for tracking.

The powder blend, including a lubricant and some recycled $\mathrm{U}_{3} \mathrm{O}_{8}$, is sent to the pellet presses. The presses are a basic design that is modified from those used in the aspirin industry. Each batch of pellets is tracked by barcode to maintain traceability of which powder batch is used. The amount of tool wear on the dies and punches is critical to prevent end capping and leads to frequent change out - often between 2 and five days. The pellets are pressed to a green density of approximately $6.7 \mathrm{gm} / \mathrm{cm}^{3}$.

Green pellets are transferred to molybdenum "boats" for sintering. The boats are open top containers about half the size of a shoebox. An automated handler picks up many of the green pellets (guessing $50+$ ) at a time using air suction and loads them into the boats. The pellets are not arranged in any orderly fashion in the boats - simply loosely placed within - to a depth of maybe 2 inches. Some dimension checks of the green pellets are conducted on grab samples as they leave the press- there are plans for implementing more rigorous QA controls at this step in the future.

Boats filled with pellets are moved into furnace for sintering at approximately $1700^{\circ} \mathrm{c}$. Sintered pellets were subsequently wet ground to their final diameter and dried, the OD was automatically checked with 
feedback to the grinder, and finally loaded into grooved trays for visual inspection. This manual, handson inspection leads to approximately $3 \%$ rejected pellets.

Any rejected pellets or in-process materials are recycled by burning to $\mathrm{U}_{3} \mathrm{O}_{8}$. This material is blended back into powder streams - it is added to increase porosity of the green pellets.

\section{Fuel Rod Loading}

Completed pellets are segregated by batch, stored in rolling cabinets and moved to a "staging" area. Here the "design" of the fuel rods is developed in accordance with the contract. Working in batches for 25 fuel rods, trays with 25 grooves are used to set up the correct numbers and types of pellets required for each rod. Depending on the customer requirements - a rod may be made up completely of a single enrichment of fuel pellet, but more likely each rod will have multiple zones. For example, we observed an operator build a set of rods with three zones. There was a blanket zone of annular, low enrichment pellets at both the bottom and top of the rod, with a center zone made up of $4.6 \%$ enriched solid pellets. The required pellets are staged on the trays in proper proportion and arrangement, with barcodes for tracing the powder batches included, before being sent to the rod assembly area to be loaded.

To load the rods, 25 tubes with the bottom plug already girth welded in place are clamped by hand into the vibrating loading fixture. The barcodes off each rod are read into the computer followed by the code from each batch of pellets. The grooved tray with the first zone of pellets is placed in the fixture, once the operator verifies the pellet batch and the number of pellets; a pusher-stick is used to slide all 25 stacks of pellets onto the vibrating feeder. The pellets then vibrate their way into the rod. Likewise, the subsequent zones of pellets are loaded. After the enriched zone was completely loaded, the operator used a go-no go gauge to verify the column height - once confirmed or adjusted to the proper height, the top blanket zone was loaded and another gauge used to confirm the total height. Plenum springs where loaded into the rods as they worked their way across a stepping conveyor. The top seal plug (with gas charging hole) was pressed into place and girth welded. The rod was then charged with high-pressure helium. Also in this area is a separate station for cutting rods that failed inspections and unloading the pellets for recycling.

\section{Rod Inspection}

The rods are then sent for inspection. The welds are gauged to assure seal the plug is straight and the OD isn't too large. The rods are manually rolled on granite inspection tables to check for bends or warps and visually inspected for abrasions or other possible defects. The welds are x-rayed and then depending on customer requirements, the rods are UT and/or gamma scanned. 
The inspected rods are bulk stored in simple channel shaped metal trays. These trays can be handled by forklift or are loaded on to special carts to be manually moved to and from the assembly area.

\section{Assembly Area}

In the assembly area, an appropriate grid design is selected based on reactor design and customer requirements and it is placed in a horizontal fixture. The primary design and process difference is between the BWR and PWR assembly. In the Westinghouse 17x17 PWR design, the fuel rods are "pulled" into the assembly whereas the BWR rods are pushed. To load an assembly, the proper fuel rod types are gathered. A template is used for each rod type to assure proper orientation within the assembly. Once all the rods are arranged, the barcodes and positions are entered into the computer to record the exact configuration of each fuel assembly. The rods are then completely inserted into the assembly grid and the top plate is installed. The assembly is up-ended from the assembly fixture and is maintained in the upright position until prepared for shipment.

Care is taken during assembly to ensure no foreign objects are caught within. Water is flushed through the grids while the rods are inserted in the BWR assemblies to provide lubrication and flush away any particulates. Each crane hook that handles the assemblies has a protective hood to prevent lubricants and metallic particles from falling onto the assembly.

\section{Final Inspection and Shipping}

The assemblies are visually inspected and dimensionally checked and adjusted as required. Once a final wash is complete, the assemblies are wrapped in a temporary fire resistant blanket required by the insurance companies to minimize the source term in the event of a fire.

For shipment, each assembly is wrapped in a plastic wrap and placed in a shipping strong back. Up to four assemblies are rotated to horizontal in the shipping containers and fixed into place. Accelerometers are placed on the inside and out of the containers to verify that the assemblies haven't seen undue stresses during shipping.

\section{Burnable Poison Pellets}

In addition to the traditional UOX fuels, the Westinghouse plant produces two pellet types that incorporate burnable poisons. One line produces an erbia/uranium oxide pellet. Although the erbia pellets utilize almost the same manufacturing process and equipment as the UOX pellets, they find them somewhat more difficult to make due to the higher pressure required to press the green pellets.

The second burnable poison pellet is call the Integral Fuel Burnable Absorber (IFBA). This is a process developed by Westinghouse that used standard sintered fuel pellets that are sputter coated with zirconium diboride $\left(\mathrm{ZrB}_{2}\right)$. The boron-coated pellets have their own challenges with lessons applicable to $\mathrm{Pu}$ fuels. To begin with, completed UOX fuel pellets are placed in flat baskets and clamped in a 
cylindrical fixture. This fixture or drum is placed in a vacuum chamber where the drum rotates as the $\mathrm{ZrB}_{2}$ is atomized using an electric arc. Once the coating is complete, the pellets are inspected then they are staged on grooved trays in preparation for loading into fuel rods. This is where the IFBA rod loading diverges from the standard rod assembly. Since the boron is hygroscopic, the fuel pellets are "baked" to remove the moisture and are then moved into glove boxes for assembly. All the steps of loading these fuel rods are the same as described on the production floor, except they are completed in the low moisture, argon inerted atmosphere in the gloveboxes. Once the top plug is pressed in place, the rods are removed from the glovebox and the final girth weld, helium pressurization and seal weld are completed hands-on under ambient conditions.

Working in the gloveboxes is inefficient and arduous enough that the company is building a "dry-room" in which to move the process. This will be a low humidity room that will allow the same traditional hands on operations and maintenance utilized throughout the rest of the facility.

\section{$\underline{\text { Notes and Observations }}$}

Following are items noted during the tour with special relevance or concern to the AFCI:

- The facility was essentially all hands-on operations and maintenance, including a lot of close visual inspection of the pellets, rods and assemblies.

- The handling of the green and sintered pellets is not overly cautious/gentle throughout the process. The pellets in both stages of the operation seem relatively immune to cracking or chipping, albeit approximately $3 \%$ of the finished pellets are rejected for a number of reasons and recycled.

- To make balanced fuel for the reactors, a variety of zones are defined across the core, across each assembly and even along the length of each rod. This means several powders of various enrichments along with different pellets must be made, staged and tracked prior to insertion into fuel rods. Then the rods must be staged and tracked to ensure proper placement into the fuel assemblies. Add in the need for some annular-shaped pellets and some incorporating burnable poisons, and there is a challenging materials control and accountability problem to be managed in gloveboxes or shielded cells.

- Some of AFCI designs have considered erbia as a burnable poison - the fuels plant has a more difficult time pressing those pellets. It's suggested that this shouldn't be a problem, but this is production experience of which we should be aware. 
Appendix B.

Preliminary Quantification of Fuel Cycle Worker Accident Rates 


\section{Preliminary Quantification of Fuel Cycle Worker Accident Rates}

1. Introduction. The Advanced Fuel Cycle Initiative (AFCI) has been initiated by the Department of Energy to examine attractive potential options for new commercial nuclear power fuel cycles. This report is from the Facility Cycle Safety Assessment task under the area of Systems Analysis.

The existing US nuclear fuel cycle is the "once-through" cycle of obtaining new uranium, fabricating it into fuel, burning the fuel in a light water reactor, and then storing the spent fuel. The AFCI is to identify several other fuel cycles that are attractive candidates for adoption. There are many criteria to judge in reviewing and comparing various fuel cycle pathways, among them is the safety of the process. There are several levels of safety - the public, fuel cycle workers, co-located workers, and environmental safety.

This paper offers an initial step in quantifying fuel cycle worker safety to provide AFCI researchers with data to support one area of the pathway-to-pathway comparison process. These quantification steps for personnel safety are subjective, based on judgments of similarity between fuel cycle processes and US industrial processes. The worker risk steps in the fuel cycle presented here should be considered as relative; they are just an initial judgment and do not wholly represent the safety of a given step in the fuel cycle. This initial quantification does serve to show the relative risk when several pathways are compared.

2. Description of Fuel Cycle Steps. The once-through fuel cycle is the current US fuel cycle. The steps consist of mining uranium, conversion of uranium to enrich the percentage of U-235, fabrication of the enriched uranium into fuel assemblies, uranium transport between processing steps and also to a reactor facility, uranium use in the power reactor, and then spent fuel storage. While 10CFR20.1003 defines the uranium fuel cycle as milling, conversion, enrichment, fuel fabrication and use in reactors, and reprocessing (not including mining, transportation, disposal site operations or reuse of recovered uranium), here we define the fuel cycle to include all operations. Each of the major steps - mining, conversion, fuel fabrication, transportation, and spent fuel storage is assigned a worker risk value. These risk values will be applied to the once through and the other potential fuel cycle pathways. Then the relative worker safety merits of each pathway will be delineated.

A. Uranium Mining. Mining is the initial event where new uranium is procured. Mining can be underground mining, open pit mining, or in situ leaching (ISL). The type of mining depends on the type of ore that exists and the local geology.

Underground mining of sedimentary ores is performed mainly by the room and pillar method. Veins of ore are mined by the cut and fill method. Some underground mines will crush ore to the $\sim 300 \mathrm{~mm}$ size. Then the ore is trucked to a nearby mill (Wilson, 1996). Underground mines have some principal hazards - roof collapse, getting enough fresh air to miners, keeping working conditions cool (with electrical motor 
exhaust heat, hydraulic system heat, and friction heat, temperatures can be high), keeping noise within limits, keeping air breathable despite the dust, electrical power hazards, moving large masses of ore safely, and dealing with accidents such as fires, dust explosions, etc.

Open pit mining is used for materials that are found at depths less than about 200 meters. Typically, explosives are used to break rock into benches of 5 to 20 meters height. Then miners drive progressively into the face at the bench. Open pit mining usually has advantages over underground mining, such as higher productivity, higher recovery, and safer working conditions. However, the environmental impact is greater than in underground mining. Open pit mining has concerns of wall collapse, congestion of traffic in and out of the mine, and blasting.

In situ leaching (ISL) is also called solution mining, and it has two potential advantages over the other two more traditional mining approaches (Wilson, 1996). First, leaching eliminates stripping, mining and milling of the ore, and it does not deposit waste tailings in the mining area. Second, ISL offers the possibility of uranium recovery from lower ore grades than can be achieved by the other methods. Solution mining has been used in Texas and Wyoming since the 1970's (Cochran, 1999). In ISL, typically four small wells are drilled at the corners of a 50-foot square, and then another small well is drilled at the center of the square. The center well is an injection well for the liquid solution and the corner wells are production wells that recover solution and remove uranium. The liquid solution is a mixture of water, oxidants, and an ionic complex agent; it is injected at $\sim 1 \mathrm{l} / \mathrm{s}$ under a pressure of perhaps $1.5 \mathrm{MPa}$ to mobilize and dissolve uranium from porous media such as sandstone and then the solution carries the uranium to the surface. ISL eliminates stockpiling and hauling ore, and it eliminates ore crushing, grinding, and some other milling operations. It also eliminates large-scale excavations (either at ground level or underground), and reduces risk to miners. With ISL the miners do not work underground or with explosives. ISL hazards are judged to be primarily those hazards associated with well drilling and operating pressurized liquid systems; these are hazards found with petroleum and gas production (FOP, 2002). For that reason, ISL is modeled as the oil and gas extraction process in petroleum production that uses injection and production wells. ISL also has the hazards of radiation from some uranium decay products, notably radon gas.

Information from the US Bureau of Labor Statistics (at www.bls.gov) was used to provide petroleum industry values. These injury and fatality rates are based on labor hours, with 2,000 hours being a typical person-year of work. The "oil and gas extraction" subset of mining cited 71 worker fatalities and 3.4 injuries per 100 workers in 2002. The uranium raw material industry in the US is not large; in 2002 employment was only 426 person-years (EIA, 2003). US mine production of uranium is by ISL; there were three commercially operating uranium mines during 2002; the Smith RanchHighland mine complex in Wyoming, the Highland mine in Wyoming, and the Crow Butte mine in Nebraska. All 3 mines used the ISL process, so applying the oil and gas extraction values to uranium mining is reasonable. The mines produced $2.3 \mathrm{E}+06$ pounds of $\mathrm{U}_{3} \mathrm{O}_{8}$ in 2002 . 
The Smith Ranch mine (Stover, 1997) uses anionic resin ion-exchange treatment to remove the uranium oxides from the ISL solution. A salt-water solution is added to saturated resin to strip the uranium oxides. Eluted uranium is precipitated, washed to remove impurities, and the yellow cake $\left(\mathrm{U}_{3} \mathrm{O}_{8}\right)$ is dried and packaged in metal drums for truck shipment to an enrichment plant. There are few public risks from ISL. The Wyoming Department of Environmental Quality has granted approval to operate such mines (Stover, 1997). Tables B-1 and B-2 give worker fatality and injury values for analogous industries.

B. Uranium Enrichment. This is the step where the natural uranium, whose isotopic abundance of U-235 is $0.7 \%$ by weight, is typically enriched to the 2 to $4 \%$ range because US commercial power reactors are designed to use enriched uranium rather than natural uranium. The US NRC allows up to 5\% enrichment in U-235; higher burnup fractions in world reactors are pushing fuel to the 5\% level (Vesterlund, 1998). For mines that produce ore, moving ore is expensive, so the mill is usually very close to the mine. Yellow cake $\left(\mathrm{U}_{3} \mathrm{O}_{8}\right)$ is produced in the mill; yellow cake is a solid material that is more easily shipped than ore. The yellow cake is the basic feed material for uranium conversion or enrichment. There were two initial approaches used for uranium enrichment in the 1940's. One was electromagnetic separation of uranium isotopes and the other was gaseous diffusion. Gaseous diffusion of uranium hexafluoride gas was found to be more cost effective and had higher output than electromagnetic separation (Cochran, 1999). Europe began its uranium enrichment in the 1960's and has favored the less energy-intensive centrifugal enrichment process (Wilson, 1996). A more recent idea is the use of tuned lasers to ionize only the U-235 isotope in uranium metal vapor; however, the existing commercial approach in the US is gaseous diffusion.

The first step in gaseous diffusion is to convert the yellow cake to a gaseous uranium compound. As part of conversion, the yellow cake must have elemental impurities removed. These impurities can include boron, cadmium, chlorine, and rare earth elements. In the US, there are two purification approaches; both are based on chemical extraction of uranium compounds from the impurities by using organic solvents (Benedict, 1957; Cochran, 1999). After purification, the gas is formed. Uranium hexafluoride $\left(\mathrm{UF}_{6}\right)$ gas was chosen since it is the only known uranium gaseous compound at moderate temperatures; in fact, it is a solid at room temperature. Also, Fluorine is a low atomic weight element; it does not interfere in the diffusion process (Cochran, 1999).

Solvent extraction processes may use organic solvents, such as diethyl ether, methyl isobutyl ketone, and tributyl phosphate (Cochran, 1999). These are chemicals that pose hazards of toxic exposure, flammability, and environmental pollution. In this way, the purification processes are similar to the industrial organic chemical industry that handles hazardous chemicals.

The diffusion plant has many sets of thin barriers for the gas to traverse. These thin barriers have numerous tiny pores, billions per square inch. At constant temperature, the few ${ }^{235} \mathrm{UF}_{6}$ molecules will diffuse through these pores slightly faster than the ${ }^{238} \mathrm{UF}_{6}$ 
molecules. The difference is slight, but after traversing a barrier, the gas stream is slightly enriched in U-235 molecules. To reach 2 to $4 \%$ enrichment, many sets of the thin barriers must be traversed, so the diffusion plant is designed to have "cascades" or set after set of gas barriers. Since uranium is mainly an alpha particle emitter, its radiation does not penetrate the steel walls of the diffusion chambers. But air inleakage is a concern; if air or water enters, the uranium forms solid compounds and if these contain a high percentage of U-235 there is a criticality concern. Leaks of gaseous $\mathrm{UF}_{6}$ are a radiological exposure and health concern for workers (Cochran, 1999). The diffusion plant consumes a great deal of electrical power to operate large gas compressors that provide differential pressure across the thin barriers, heat the system to $\sim 60^{\circ} \mathrm{C}$, operate vacuum pumps that evacuate air out of the system, etc. Wilson (1996) speculated that since diffusion plants required many stages (very high capital equipment investment cost), had high power consumption, required large process inventories, and the process was ill suited to recycling uranium where contaminants tend to remain in the plant for many months, that no more diffusion plants would ever be built.

The diffusion plant is not very similar to most manufacturing or chemical process industry operations; however, it does bear a few similarities to a natural gas distribution and transmission facility. A natural gas facility has sets of modest pressure compressors that consume energy, large amounts of gas being handled, similar amounts of capital equipment (i.e., pipelines, compressors, storage tanks), and it operates continuously. For these reasons, the natural gas distribution network is used as an analogous process to give a preliminary value of occupational risk at a diffusion plant. 
Table B-1. Worker Risk Values from BLS Data

\begin{tabular}{|c|c|c|c|c|c|c|c|c|}
\hline \multirow{2}{*}{$\begin{array}{l}\text { Industry } \\
\text { and work } \\
\text { force count }\end{array}$} & \multirow[b]{2}{*}{$\begin{array}{l}\text { Analo- } \\
\text { gous } \\
\text { fuel } \\
\text { cycle } \\
\text { pro- } \\
\text { cess }\end{array}$} & \multirow{2}{*}{$\begin{array}{l}2002 \\
\text { BLS } \\
\text { Fatal- } \\
\text { ities }\end{array}$} & \multicolumn{6}{|c|}{ Percentage due to event or exposure } \\
\hline & & & $\begin{array}{l}\text { Transpor- } \\
\text { tation } \\
\text { incidents }\end{array}$ & $\begin{array}{l}\text { Violent } \\
\text { acts }\end{array}$ & $\begin{array}{l}\text { Contact } \\
\text { with } \\
\text { Objects } \\
\text { or Eq. }\end{array}$ & Falls & $\begin{array}{l}\text { Harmful } \\
\text { exposure }\end{array}$ & $\begin{array}{l}\text { Fires and } \\
\text { explosions }\end{array}$ \\
\hline $\begin{array}{l}\text { Oil \& gas } \\
\text { extraction } \\
337,000\end{array}$ & $\begin{array}{l}\text { ISL } \\
\text { mining }\end{array}$ & 71 & 35.2 & -- & 25.4 & 8.5 & 12.7 & 15.5 \\
\hline $\begin{array}{l}\text { Trucking } \\
1,854,000\end{array}$ & $\begin{array}{l}\text { Trans- } \\
\text { port } \\
\text { mater- } \\
\text { ials }\end{array}$ & 352 & 84.1 & 4.0 & 5.1 & 3.4 & 3.1 & -- \\
\hline $\begin{array}{l}\text { Manufac- } \\
\text { turing } \\
\text { industrial } \\
\text { inorganic } \\
\text { and organic } \\
\text { chemicals } \\
96,000 \text { and } \\
118,000\end{array}$ & $\begin{array}{l}\text { Yellow } \\
\text { cake } \\
\text { convers } \\
\text { ion }\end{array}$ & $\begin{array}{l}5 \\
\text { and } \\
3 \\
\text { total }= \\
8\end{array}$ & $\begin{array}{l}-- \\
--\end{array}$ & -- & -- & -- & $\begin{array}{l}-- \\
--\end{array}$ & $\begin{array}{l}60 . \\
--\end{array}$ \\
\hline $\begin{array}{l}\text { Gas } \\
\text { production } \\
\text { and } \\
\text { distribution } \\
124,000\end{array}$ & $\begin{array}{l}\text { UF6 } \\
\text { enrich- } \\
\text { ment }\end{array}$ & 6 & 50. & -- & -- & -- & -- & -- \\
\hline $\begin{array}{l}\text { Manufac- } \\
\text { turing } \\
\text { electronic } \\
\text { compo- } \\
\text { nents and } \\
\text { accessories } \\
647,000\end{array}$ & $\begin{array}{l}\text { Fuel } \\
\text { fabri- } \\
\text { cation }\end{array}$ & 7 & -- & -- & -- & -- & -- & -- \\
\hline $\begin{array}{l}\text { Electric } \\
\text { services } \\
354,000\end{array}$ & $\begin{array}{l}\text { power } \\
\text { plant } \\
\text { opera- } \\
\text { tion }\end{array}$ & 35 & 28.6 & -- & 8.6 & -- & 42.9 & 11.4 \\
\hline
\end{tabular}

Work force employee counts from the Statistical Abstract of the United States: 2002, US Census Bureau, Washington, DC, 2002, ch. 12, Table 603, available at www.census.gov; and fatality counts from the Department of Labor, Bureau of Labor Statistics, fatalities for 2002, available at www.bls.gov. 
Table B-2. Worker Injury Values from BLS Data

\begin{tabular}{|c|c|c|c|c|c|c|}
\hline \multirow[t]{2}{*}{ Industry } & \multirow{2}{*}{$\begin{array}{c}\text { Analogous } \\
\text { fuel cycle } \\
\text { process }\end{array}$} & \multirow{2}{*}{$\begin{array}{l}2002 \text { BLS } \\
\text { injury } \\
\text { rate per } \\
100 \\
\text { workers } \\
\text { per year }\end{array}$} & \multicolumn{4}{|c|}{$\begin{array}{l}\text { Recordable Cases with days away from work, } \\
\text { job transfer or restriction }\end{array}$} \\
\hline & & & Total & $\begin{array}{c}\text { Cases } \\
\text { with } \\
\text { days } \\
\text { away } \\
\text { from } \\
\text { work }\end{array}$ & $\begin{array}{c}\text { Cases } \\
\text { with job } \\
\text { transfer or } \\
\text { restriction }\end{array}$ & $\begin{array}{c}\text { Other } \\
\text { recordable } \\
\text { cases }\end{array}$ \\
\hline $\begin{array}{l}\text { Oil \& gas } \\
\text { extraction }\end{array}$ & $\begin{array}{l}\text { ISL } \\
\text { mining }\end{array}$ & 3.4 & 2.2 & 1.5 & 0.7 & 1.3 \\
\hline Trucking & $\begin{array}{l}\text { Trans- } \\
\text { porting } \\
\text { materials }\end{array}$ & 6.8 & 4.5 & 3.3 & 1.2 & 2.3 \\
\hline $\begin{array}{l}\text { Manufacturing } \\
\text { organic } \\
\text { chemicals }\end{array}$ & $\begin{array}{l}\text { Yellow } \\
\text { cake } \\
\text { conversio } \\
\mathrm{n}\end{array}$ & 2.2 & 1.2 & 0.6 & 0.6 & 1.1 \\
\hline $\begin{array}{l}\text { Gas } \\
\text { production } \\
\text { and } \\
\text { distribution }\end{array}$ & $\begin{array}{l}\text { UF6 } \\
\text { enrich- } \\
\text { ment }\end{array}$ & 3.4 & 2.2 & 1.5 & 0.7 & 1.3 \\
\hline $\begin{array}{l}\text { Manufacturing } \\
\text { inorganic } \\
\text { chemicals, } \\
\text { and } \\
\text { Manufacturing } \\
\text { electronic } \\
\text { components } \\
\text { and } \\
\text { accessories }\end{array}$ & $\begin{array}{l}\text { Fuel pellet } \\
\text { fabrication }\end{array}$ & $\begin{array}{c}2.8 \\
\text { and } \\
3.1 \\
\text { total }=5.9\end{array}$ & $\begin{array}{c}1.8 \\
\text { and } \\
1.6\end{array}$ & $\begin{array}{l}0.6 \\
\text { and } \\
0.7\end{array}$ & $\begin{array}{c}1.2 \\
\text { and } \\
0.8\end{array}$ & $\begin{array}{c}1.0 \\
\text { and } \\
1.5\end{array}$ \\
\hline $\begin{array}{l}\text { Electric } \\
\text { services }\end{array}$ & $\begin{array}{l}\text { Power } \\
\text { plant } \\
\text { operation }\end{array}$ & 3.7 & 2.0 & 1.1 & 0.9 & 1.7 \\
\hline
\end{tabular}

Note: injury rates are from the Department of Labor, Bureau of Labor Statistics, injuries and illnesses for 2002, available at www.bls.gov. 
C. Fuel Fabrication. After the uranium is enriched from 2 to $5 \% \mathrm{U}-235$, the individual fuel pellets can be manufactured. The first step is to convert enriched uranium hexafluoride to uranium dioxide. The enriched $\mathrm{UF}_{6}$ is heated to sublime to gaseous state, then it is bubbled in pure water to make $\mathrm{UO}_{2} \mathrm{~F}_{2}$ in solution. Then the water solution is mixed with ammonia water to yield ammonium diuranate, which precipitates out. The precipitate is dried and heated to form yellow cake of enriched uranium. Adding hydrogen reduces the yellow cake to enriched uranium dioxide. These steps are similar to processes found in the inorganic chemical manufacturing industry. The uranium dioxide granules are ground to fine powder. The fuel is formed from this enriched uranium dioxide powder and then is pressed into the small cylindrical shape needed for assembly in a fuel rod. The cylinder is then sintered (heated at $\sim 1600^{\circ} \mathrm{C}$ ) to densify the cylinder (Cochran, 1999). This work is done in controlled atmospheric conditions to prevent any contaminants from entering the pellets or adhering to the pellet surfaces.

Typically, over a hundred thousand fuel pellets are needed for one fuel assembly. A power plant might order 60 or 65 assemblies to replace one-third of the assemblies in the core for a given refueling outage. Therefore, over five million fuel pellets are typically needed to meet a single power plant's refueling order. If one fabrication facility were supplying all the 100 nuclear power plants in the US, assuming an 18-month fuel cycle, then there would be 5 or 6 orders per month to fill, for a total of about 30 million fuel pellets per month.

Besides the chemical steps in the process, fuel fabrication bears some similarities to computer chip manufacturing. A large computer chip production plant, such as the Micron complex in Idaho, can produce on the order of 3 to 5 million chips per week (Cadwallader, 2001). The chip fabrication process uses chemicals such as nitric acid and water rinsing, the cleanliness of the workplace is carefully controlled by 'clean rooms' to preserve the purity of the chips, chips are placed under heat and pressure when encapsulated with thermosetting plastic, the chips are heat treated, the chips are remotely handled at a number of stations, and each chip is tested to determine if it meets specifications. Small trays of chips are carried by hand; bins of completed chips are handled with machinery such as lift trucks and hoists. These same steps are also used for fuel pellet manufacture - chemical processing under very clean conditions, heat and pressure processes, inspection of the pellets to ensure proper size, handling the pellets remotely to reduce contamination, etc. Therefore, the combined inorganic chemical manufacturing industry and electronics manufacturing industry work risk values are used as a first indicator of the hazard in fuel fabrication.

D. Transportation. The fuel has actually been transported in several of the steps that have been discussed. Transportation total distances are estimated for various fuel cycle options based on the distances between facilities. Since the trucking environment of acceleration, vibration, heat, etc., is not a threat to the chemical forms of uranium (yellow cake, ceramic $\mathrm{UO}_{2}$ fuel, etc.), the primary concern is accident events. In a trucking accident, it is possible to overstress or breach a container, especially a yellow cake container. There is also the rare event of a vehicle fire following an accident; a fire could lead to container breach. 
Eide (2003) has reviewed accident rates for truck and rail shipments. The basic value for a truck accident on the interstate highway system is $3.2 \mathrm{E}-07 / \mathrm{km}$. For rail cars, the representative national value for accident probability is $6.1 \mathrm{E}-08 /$ railcar-km. Eide also reported that the fatality rate is 0.028 fatalities per truck accident on interstate highways, and 0.37 fatalities per rail accident. These values can be compared to Table B-1 truck driver fatality rates when examining the kilometers to be traveled.

E. Fuel usage in power reactors. The safety of fuel in the power reactor is not our primary concern in AFCI; other tasks are devoted to reactor safety. However, the US Nuclear Regulatory Commission (NRC) has directed that Individual Plant Examinations (IPE) of risk be conducted for US nuclear power plants, and the results are presented in two reports (NRC, 1997; NRC, 2002). Fullwood (2000) summarized the internal event IPE findings as given in the Figures 2 and 3 below. The majority of the plants are below the 1E-04/reactor-year core damage frequency range and the containment failure probability is sometimes less than 1 in 10, which was recommended by the Nuclear Regulatory Commission (NRC) (Ramsey, 1998). The internal event IPE findings are easily compared among power plants; the external IPE results have used differing methodologies and are not easily compared.

Slaper (1998) takes a less rigorous approach and states that there have been two commercial reactor accidents that have caused notable offsite radiation releases, the Three Mile Island unit 2 event in 1979 and the Chernobyl unit 4 event in 1986. He gave a value of approximately 8,000 reactor-years of experience with commercial plants worldwide at the time of his writing, so the average probability of an accident with damage to the reactor core and environmental release is $\sim 2.5 \mathrm{E}-04 /$ reactor-year.

For a preliminary quantification, a value of 1E-04/reactor-year frequency of a fuel-damaging event with offsite consequences is a reasonable value to assume for US nuclear power plants. If a particular fuel cycle path means longer on-line time between refueling outages, a more detailed assessment may be needed to address the benefits of that issue.

Power plant operation is covered by the Bureau of Labor Statistics (BLS) under 'electric services', but this category includes all types of power plants. These include coal-fired plants, oil and gas burning plants, hydroelectric dams, wind farms and solar plants, pumped storage, compressed air storage, and nuclear plants. Accurate values cannot be obtained from the BLS, there is no data resolution by type of plant.

More detailed examination has provided some information. The reader must recall that the first commercial nuclear power plant in the US was the Shippingport PWR that came on line in 1957, and the next plants were the Dresden I BWR and the Yankee Rowe PWR in 1960, and the Big Rock Point BWR in 1963. There were 18 plants on line by mid-1965. After that, dozens more plants came on line in the rest of the 1960's and the 1970's. There are now just over 100 operating power plants in the US. 
The earliest data located was a series of reports that the US Atomic Energy Commission requested from the Bureau of Labor Statistics (BLS) of the US Department of Labor. These data spanned 1965-1970 (BLS, 1967; BLS, 1969; BLS, 1970; BLS, 1971, BLS, 1972) and are presented in Table B-3. 


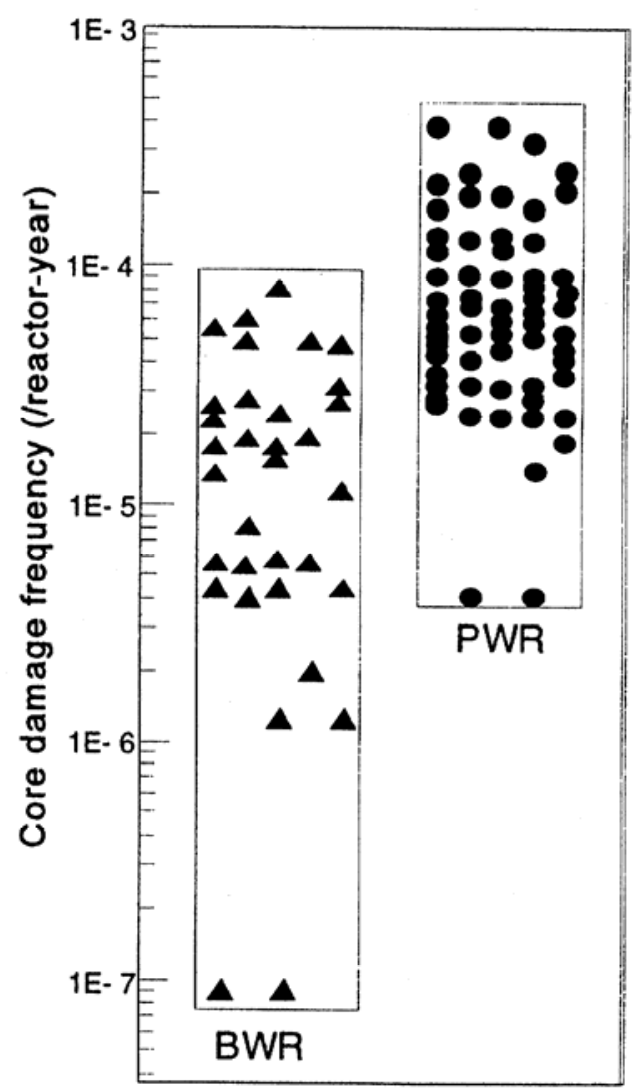

Figure B-1. A plot of power reactor core damage frequencies from the NRC IPE results (taken from Fullwood, 2000).

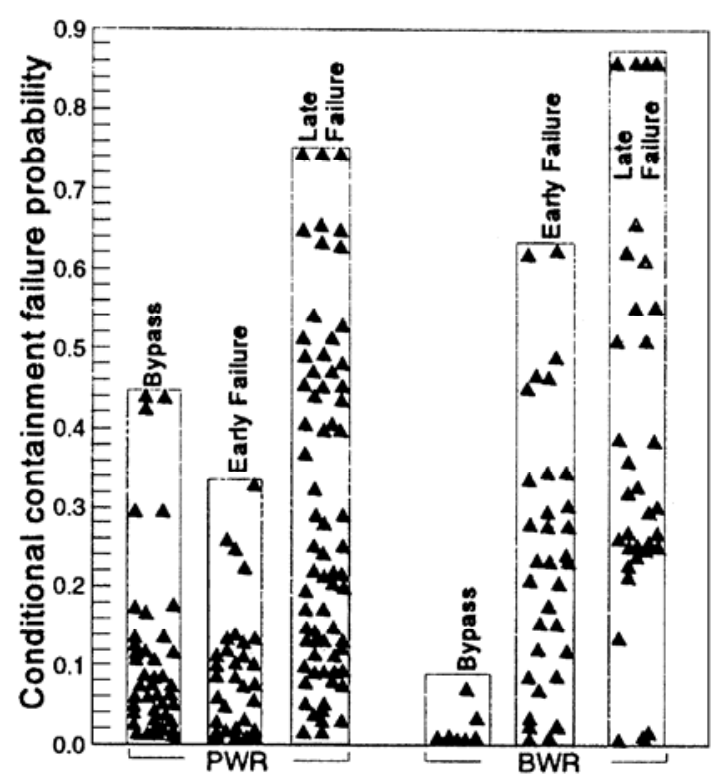

Figure B-2. A plot of containment failure probabilities from the NRC IPE results (taken from Fullwood, 2000). 
Other sources of data are also available. O'Donnell (1981) referred to the data in Table B-4, and they used plant data from the Tennessee Valley Authority, that was operating several nuclear power plants at that time (Browns Ferry 1, 2, and 3 were all operational by 1977; the Sequoyah and Watt's Bar plants came later). This is only a small sample of the 100 US power plants that now operate.

\begin{tabular}{|c|c|c|c|c|}
\hline Incidence Rates & $\underline{1975}$ & $\underline{1976}$ & $\underline{1977}$ & \\
\hline $\begin{array}{l}\text { fatalities } \\
\text { per } 100 \text { man-years }\end{array}$ & 0.0 & 0.0 & 0.0 & (note: they assumed $0.01 / 100$ man-years) \\
\hline $\begin{array}{l}\text { Serious injuries } \\
\text { per } 100 \text { man-years }\end{array}$ & 0.38 & 0.27 & 1.7 & \\
\hline
\end{tabular}

Cochran (1999) reported some data from a Nuclear News article (NN, 1981) that outlined worker injury rates that had been complied for a United Kingdom safety report; this report also cited other data sources. Operating a nuclear power station of 1,000 MWe at $75 \%$ availability gave these results:

\begin{tabular}{lll} 
& \multicolumn{2}{c}{ Nuclear power plant annual operation (including reprocessing) } \\
\cline { 2 - 2 } Study & Accidental injuries per 750 MWe & Accidental deaths per 750 MWe \\
Inhaber & 1.37 & $0.01-0.013$ \\
Norwegian & $0.7-2.8$ & $0.01-0.2$ \\
Swedish & 11.1 & 0.03 \\
WASH-1224 & 1.42 & 0.012 \\
Comar \& Sagan & 1.3 & 0.01 \\
Fagnani \& Maccia & 4.9 & 0.013 \\
Hamilton & 1.3 & 0.015 \\
Black \& Niehaus & 3.48 & 0.011 (this value excludes reprocessing) \\
& & \\
Ranges & $0.7-11.1$ & $0.01-0.2$
\end{tabular}

To convert the UK report values to injuries and fatalities per worker-year, the average number of workers at a nuclear power plant is needed. Not all the sources above were US data, but we only have available counts of US workers at nuclear plants. Therefore, the conversion will only be applied to the ranges of values. The annual radiation exposure NUREG (Burrows, 2002) gives the number of workers monitored for radiation exposure in all of the 104 commercial power plants in the US. This number of monitored workers was 140,776 for 2001 and the average number of workers per plant is rounded off to 1,350. We note that the Statistical Abstract of the US for 2002 cited 354,000 workers in the overall electrical services industry (code 491). Therefore, nuclear plants that produce about $20 \%$ of the nation's power employ $\sim 40 \%$ of the electric services workers, meaning that nuclear plants are more highly staffed than coal-fired, hydroelectric, and other types of power plants. As a first approximation, we assume that most of the US plants are large output; this is reasonable since the first several plants that were small power output have been decommissioned (e.g., Shippingport, Dresden 1, Big 
Rock Point). Using this average number of workers per plant value to match the 1,000 MWe plant, we find new range values for the data given above:

Nuclear power plant annual operation (including reprocessing)

Study Accidental injuries per $750 \mathrm{MWe}$ Accidental deaths per $750 \mathrm{MWe}$

Adjusted Ranges $\quad 5.19 \mathrm{E}-04-8.22 \mathrm{E}-03 \quad 7.4 \mathrm{E}-06-1.48 \mathrm{E}-03$ 
Table B-3. Early Values of Occupational Safety Rates for the Nuclear Industry

\begin{tabular}{|c|c|c|c|c|c|c|}
\hline \multirow[b]{2}{*}{ Type of Activity } & \multicolumn{6}{|c|}{ Annual Injury Frequency Rate } \\
\hline & 1965 & 1966 & 1967 & 1968 & 1969 & 1970 \\
\hline $\begin{array}{l}\text { Production of special } \\
\text { materials for use in } \\
\text { reactors } \\
\text { (graphite, beryllium, } \\
\text { etc.) }\end{array}$ & $\begin{array}{c}9.2 \\
(0.018)\end{array}$ & $\begin{array}{c}13.3 \\
(0.027)\end{array}$ & $\begin{array}{c}25.2 \\
(0.050)\end{array}$ & $\begin{array}{c}36.8 \\
(0.074)\end{array}$ & $\begin{array}{c}28.2 \\
(0.056)\end{array}$ & $\begin{array}{c}42.6 \\
(0.085)\end{array}$ \\
\hline $\begin{array}{l}\text { Fuel element } \\
\text { fabrication }\end{array}$ & $\begin{array}{c}4.2 \\
(0.008)\end{array}$ & $\begin{array}{c}4.6 \\
(0.009)\end{array}$ & $\begin{array}{c}6.9 \\
(0.014)\end{array}$ & $\begin{array}{c}5.3 \\
(0.011)\end{array}$ & $\begin{array}{c}7.1 \\
(0.014)\end{array}$ & $\begin{array}{c}6.4 \\
(0.013)\end{array}$ \\
\hline $\begin{array}{l}\text { Reactor and reactor } \\
\text { component design and } \\
\text { manufacture }\end{array}$ & $\begin{array}{c}4.2 \\
(0.008)\end{array}$ & $\begin{array}{c}4.0 \\
(0.008)\end{array}$ & $\begin{array}{c}2.8 \\
(0.006)\end{array}$ & $\begin{array}{c}4.8 \\
(0.01)\end{array}$ & $\begin{array}{c}4.7 \\
(0.01)\end{array}$ & $\begin{array}{c}3.3 \\
(0.007)\end{array}$ \\
\hline $\begin{array}{l}\text { Design and engineering } \\
\text { of nuclear facilities }\end{array}$ & $\begin{array}{c}7.2 \\
(0.014) \\
\end{array}$ & $\begin{array}{c}5.9 \\
(0.012) \\
\end{array}$ & $\begin{array}{c}10.5 \\
(0.021) \\
\end{array}$ & $\begin{array}{c}1.4 \\
(0.003) \\
\end{array}$ & $\begin{array}{c}1.6 \\
(0.003) \\
\end{array}$ & $\begin{array}{c}2.3 \\
(0.005) \\
\end{array}$ \\
\hline $\begin{array}{l}\text { Power reactor operation } \\
\text { and maintenance }\end{array}$ & $\begin{array}{c}3.3 \\
(0.007)\end{array}$ & $\begin{array}{c}3.9 \\
(0.008)\end{array}$ & $\begin{array}{c}5.0 \\
(0.01)\end{array}$ & $\mathrm{n} / \mathrm{c}$ & $\mathrm{n} / \mathrm{c}$ & $\begin{array}{c}7.9 \\
(0.016) \\
\end{array}$ \\
\hline $\begin{array}{l}\text { Nuclear instruments } \\
\text { manufacturing }\end{array}$ & $\begin{array}{c}3.8 \\
(0.008)\end{array}$ & $\begin{array}{c}5.8 \\
(0.012)\end{array}$ & $\begin{array}{c}5.5 \\
(0.011)\end{array}$ & $\begin{array}{c}6.8 \\
(0.014)\end{array}$ & $\begin{array}{c}6.2 \\
(0.012)\end{array}$ & $\begin{array}{c}7.9 \\
(0.016)\end{array}$ \\
\hline $\begin{array}{l}\text { Processing and } \\
\text { packaging } \\
\text { radioisotopes }\end{array}$ & $\begin{array}{c}1.3 \\
(0.003)\end{array}$ & $\begin{array}{c}1.8 \\
(0.004)\end{array}$ & $\begin{array}{c}7.9 \\
(0.016)\end{array}$ & $\begin{array}{c}6.5 \\
(0.013)\end{array}$ & $\mathrm{n} / \mathrm{c}$ & $\begin{array}{c}4.5 \\
(0.009)\end{array}$ \\
\hline Private research labs & $\begin{array}{c}3.7 \\
(0.007) \\
\end{array}$ & $\begin{array}{c}4.7 \\
(0.009) \\
\end{array}$ & $\begin{array}{c}2.7 \\
(0.005) \\
\end{array}$ & $\begin{array}{c}4.0 \\
(0.008) \\
\end{array}$ & $\begin{array}{c}4.6 \\
(0.009) \\
\end{array}$ & $\begin{array}{c}4.0 \\
(0.008) \\
\end{array}$ \\
\hline $\begin{array}{l}\text { Injury distribution }(\%) \\
\text { death } \\
\text { permanent impairments } \\
\text { temporary impairments }\end{array}$ & $\begin{array}{c}1.1 \\
5.8 \\
93.1 \\
\end{array}$ & $\begin{array}{c}1.3 \\
4.7 \\
94.0 \\
\end{array}$ & $\begin{array}{c}0.5 \\
2.9 \\
96.6 \\
\end{array}$ & $\begin{array}{c}1.0 \\
3.3 \\
95.7 \\
\end{array}$ & $\begin{array}{c}0.7 \\
3.8 \\
95.5 \\
\end{array}$ & $\begin{array}{c}0.8 \\
2.6 \\
96.6\end{array}$ \\
\hline $\begin{array}{l}\text { Notes: The injury frequ } \\
\text { per year. Assuming a st } \\
\text { per year. The second nu } \\
\text { "n/c" stands for not cite } \\
\text { reliability (e.g., low valu }\end{array}$ & $\begin{array}{l}\text { he data } \\
\text { of man }\end{array}$ & omit & $\begin{array}{l}\text { f they } \\
\text { were re }\end{array}$ & $\begin{array}{l}\text { of que } \\
\text { ted to } B\end{array}$ & $\begin{array}{l}\text { employ } \\
\text { er } 500\end{array}$ & $\begin{array}{l}\text { hours } \\
\text { kers } \\
\text { istical }\end{array}$ \\
\hline
\end{tabular}


The US industry has had a recent publication of occupational safety data $(\mathrm{NN}$, 2001). These data were compiled by the US Institute of Nuclear Power Operations (INPO). Their compilation was based on 200,000 worker-hours, with a standard work year being 2,000 hours. Yearly aggregate values for lost work time injuries, injuries resulting in restricted work, and fatalities (combined under the term "accidents") for nuclear power plants have been given as:

\begin{tabular}{lll} 
Calendar year & $\begin{array}{l}\text { Accidents per } \\
\text { 200,000 worker-hours }\end{array}$ & $\begin{array}{l}\text { Accidents per } \\
\text { worker-year }\end{array}$ \\
\cline { 2 - 2 } 1980 & 2.10 & 0.0210 \\
1984 & 1.50 & 0.0150 \\
1988 & 1.34 & 0.0134 \\
1990 & 1.03 & 0.0103 \\
1992 & 0.77 & 0.0077 \\
1994 & 0.64 & 0.0064 \\
1996 & 0.46 & 0.0046 \\
1998 & 0.29 & 0.0029 \\
1999 & 0.34 & 0.0034 \\
2000 & 0.26 & 0.0026
\end{tabular}

The stated 1998-1999-2000 goal value was 0.40 accidents/200,000 worker-hours. Note the factor of 8 decrease in the accident rate from 1980 to 2000 , even though the number of plants coming on line was still slowly increasing throughout the 1980's. INPO has also published a performance indicators update (INPO, 2003) that gives 2001 and 2002 values of 0.24 and 0.22 accidents per 200,000 worker-hours.

The World Association of Nuclear Operators (WANO) has also published some occupational safety data that has been shared from member utilities (WANO, 2004). The accident rate is for industrial accidents that result in lost work time, restricted work, or fatalities. These data are summarized below for comparison to the Nuclear News/INPO data:

\begin{tabular}{lccl}
$\begin{array}{l}\text { Calendar } \\
\text { Year }\end{array}$ & $\begin{array}{c}\text { Number of } \\
\text { Power Plants Reporting }\end{array}$ & $\begin{array}{c}\text { Accident Rate per } \\
\text { 200,000 man-hours }\end{array}$ & $\begin{array}{l}\text { Accident Rate } \\
\text { per worker-yr }\end{array}$ \\
\cline { 3 - 4 } 1990 & 169 & 1.04 & 0.0104 \\
1994 & 175 & 0.80 & 0.0080 \\
1996 & 183 & 0.63 & 0.0063 \\
1998 & 198 & 0.51 & 0.0051 \\
2000 & 202 & 0.42 & 0.0042 \\
2001 & 203 & 0.33 & 0.0033 \\
2002 & 200 & 0.33 & 0.0033 \\
2003 & 203 & 0.31 & 0.0031 \\
& 201 & 0.28 & 0.0028
\end{tabular}

Note that the US is a member of WANO, and the count of US nuclear power plants in the 1990-2003 time span was about 100; consequently there are data from other countries as 
well as US data represented in this table. The numbers closely agree between the Nuclear News/INPO values and the WANO values.

An issue here is how to decompose the reported "accident" data into fatality and injury events. The earliest data compiled by the BLS held some percentage values that have been given at the bottom of Table B-4. It is reasonable to assume that two factors would tend to reduce the cited percentages of death in occupational accidents. The first is the OSHA regulations that came into effect in 1971. While the set of BLS reports shows that the nuclear industry was generally experiencing fewer incidents than general industry, some aspects of the OSHA regulations would still impact power plant safety; for example, electrical safety and ladder safety regulations. The OSHA regulations have had the overall industry effect of reducing occupational fatalities throughout the country. From the National Institute of Occupational Safety and Health ${ }^{1}$ :

"The numbers and rates of traumatic occupational fatalities declined from 1980 through 1998. The number of fatal occupational injuries decreased $35 \%$, from 7,343 fatalities in 1980 to 4,798 in 1998 . The annual fatality rate per 100,000 civilian workers decreased $47 \%$, from 7.4 in 1980 to 3.9 in 1998."

The second factor is the increasing medical knowledge and increased levels of emergency medical care, with paramedics and emergency medical technicians that can administer first aid much more quickly than the 1950's and 1960's ambulances that merely transported an injured person to a hospital. The exact count of recent annual fatalities at nuclear power plants is not readily available, but fatality counts are only a few persons each year from electrocutions, vehicle accidents, falls and other events. Considering 2002, when a worker was electrocuted while trimming tree branches near a $138 \mathrm{kV}$ line on a reactor site (NRC, 2002a), the fatal accident ratio is $1 / 140,776$ or $7.1 \mathrm{E}-$ 06 fatalities per worker-year. Combining with 0.0022 accidents per worker-year for 2002 from INPO, the fatality percentage is $0.32 \%$. Comparing to the data in Table B-4, this is a small decrease in the fatality percentage, but the industry has also expanded a great deal in $\sim 30$ years.

An overall table of the commercial power plant operation occupational safety data is given below, on a per worker basis.

\begin{tabular}{|c|c|c|c|}
\hline Year & $\begin{array}{l}\text { Accident rate } \\
\text { per worker-year }\end{array}$ & $\begin{array}{l}\text { Fatality rate } \\
\text { per worker-year }\end{array}$ & $\underline{\text { Source }}$ \\
\hline 1965 & 0.007 & 7.7E-05 & BLS, 1967 \\
\hline 1966 & 0.008 & $1.0 \mathrm{E}-04$ & BLS, 1967 \\
\hline 1967 & 0.01 & $5.0 \mathrm{E}-05$ & BLS, 1969 \\
\hline 1968 & $\mathrm{n} / \mathrm{c}$ & $\mathrm{n} / \mathrm{c}$ & BLS, 1970 \\
\hline 1969 & $\mathrm{n} / \mathrm{c}$ & $\mathrm{n} / \mathrm{c}$ & BLS, 1971 \\
\hline
\end{tabular}

${ }^{1} \mathrm{http} / /$ www.cdc.gov/niosh/injury/traumatrend.html 


$\begin{array}{llll}1970 & 0.016 & 1.3 \mathrm{E}-04 & \text { BLS, 1972 } \\ & & & \\ 1975 & 0.0038 & 1 \mathrm{E}-04 \text { (assumed) } & \text { O'Donnell, 1981, only 2 plants } \\ 1976 & 0.0027 & 1 \mathrm{E}-04 \text { (assumed) } & \text { O'Donnell, 1981, only 2 plants } \\ 1977 & 0.017 & 1 \mathrm{E}-04 \text { (assumed) } & \text { O'Donnell, 1981, only 3 plants }\end{array}$

\begin{tabular}{|c|c|c|c|}
\hline Year & $\begin{array}{l}\text { Accident rate } \\
\text { per worker-year }\end{array}$ & $\begin{array}{l}\text { Fatality rate } \\
\text { per worker-year }\end{array}$ & $\underline{\text { Source }}$ \\
\hline 1980 & 0.0210 & $1.3 \mathrm{E}-04$ & NN, 2001, (assumed $0.6 \%$ deaths) \\
\hline 1984 & 0.0150 & $9.0 \mathrm{E}-05$ & NN, 2001 , (assumed $0.6 \%$ deaths) \\
\hline 1988 & 0.0134 & 8.0E-05 & NN 2001, (assumed $0.6 \%$ deaths) \\
\hline 1990 & 0.0103 & 4.6E-05 & NN, 2001 , (assumed $0.6 \%$ deaths) \\
\hline 1992 & 0.0077 & $3.5 \mathrm{E}-05$ & NN, 2001, (assumed $0.45 \%$ deaths) \\
\hline 1994 & 0.0064 & 2.9E-05 & NN, 2001, (assumed $0.45 \%$ deaths) \\
\hline Year & $\begin{array}{l}\text { Accident rate } \\
\text { per worker-year }\end{array}$ & $\begin{array}{l}\text { Fatality rate } \\
\text { per worker-year }\end{array}$ & $\underline{\text { Source }}$ \\
\hline 1996 & 0.0046 & $2.1 \mathrm{E}-05$ & NN, 2001, (assumed $0.45 \%$ deaths) \\
\hline 1998 & 0.0029 & $1.3 \mathrm{E}-05$ & NN, 2001, (assumed $0.45 \%$ deaths) \\
\hline 1999 & 0.0034 & $1.5 \mathrm{E}-05$ & NN, 2001, (assumed $0.45 \%$ deaths) \\
\hline 2000 & 0.0026 & 8.3E-06 & NN, 2001, (used $0.32 \%$ deaths) \\
\hline 2001 & 0.0024 & 7.7E-06 & INPO, 2003, (used $0.32 \%$ deaths) \\
\hline 2002 & 0.0022 & $7.0 \mathrm{E}-06$ & INPO, 2003 , (used $0.32 \%$ deaths) \\
\hline
\end{tabular}

The comparison values show that the accident rates at nuclear power plants have been decreasing with time.

Yearly aggregate values for lost work time injuries, injuries resulting in restricted work, and fatalities for nuclear power plants (NN, 2001) have been given as:

\begin{tabular}{lc} 
Calendar year & Accidents/200,000 worker-hours \\
\hline 1980 & $2.10 \quad$ (note: the OSHAct became law in 1971) \\
1984 & 1.50 \\
1988 & 1.34 \\
1990 & 1.03 \\
1992 & 0.77 \\
1994 & 0.64 \\
1996 & 0.46 \\
1998 & 0.29 \\
1999 & 0.34 \\
2000 & 0.26
\end{tabular}


The stated 1998-1999-2000 goal value was 0.40 accidents/200,000 worker-hours. Note the factor of 8 decrease in the accident rate from 1980 to 2000 .

Using the average of the last three years of reported data gives 0.33 per 200,000 worker-hours and the standard 2,000 hours/year indicates that these rates are calculated per 100 workers in a year, like the BLS injury rates (but these nuclear data also include fatalities). The nuclear power rate is 0.0033 injuries\&fatalities/worker-year. Compared to the electric services value of 0.037 injuries/worker-year, the nuclear data is slightly lower than $10 \%$ of the overall value. Using the electric services ratio between injuries and fatalities on the nuclear industry value gives a nuclear plant fatality rate of approximately 8.8E-06 fatalities per worker-year.

F. Spent fuel storage. After usage in the power reactor, the fuel is removed in a refueling outage and is allowed to decay in a spent fuel pool. The decay heat is naturally convected to the water in the pool; this is often referred to as wet storage. After several years of decay, the short-lived fission products have decayed away and the fuel self-heating from decay is reduced enough that it can be stored in dry spent fuel casks.

Eide (2003) estimated the standard industrial risk for radioactive waste workers. For workers directly involved with the waste, the fatality rate is $8.6 \mathrm{E}-09$ fatality/workerhour, and for the support personnel (those workers who provide office support) the rate is ten times lower, or 8.6E-10 fatality/worker-hour. Assuming a standard 2,000 hour work year, these values become 1.72E-05 fatality/worker-year and 1.72E-06 fatality/workeryear, for direct workers and support personnel, respectively.

3. Conclusions. This appendix presents initial results of a task to quantify worker risk in the nuclear fuel cycle processes of mining, enrichment, fuel fabrication, transportation, fuel usage, and spent fuel storage. Table B-4 gives the results for all processes. Some of the analogies are more coarse than others, but using these values in a relative manner to compare fuel cycle pathways to each other can provide worker risk insights between the candidate fuel cycle pathways. Comparisons to the 1973-1974 O'Donnell data showed that most of the commercialized parts of the process (mining, transport, yellow cake conversion and power plant operation) gave injury and fatality rates higher than the present suggested estimates. The Atomic Energy Commissioncontrolled processes of uranium enrichment and fuel fabrication showed fatality rates a factor of $\sim 2$ lower than the present estimates derived from BLS data. There has long been a contention that the US DOE operates at about $10 \%$ of the losses and fatality rates of comparable industries, but finding comparable data sets to prove or disprove this ratio is not a simple task. One existing discrepancy between the data sets is that O'Donnell used underground mining, which was the major contributor at the time, while present estimates are data inferred for ISL mining. Other discrepancies between the O'Donnell data and present estimates may be due to the last two decades of increased occupational safety in all US industries. The fact that O'Donnell showed lower values for the enrichment and fuel fabrication processes suggests that the present estimates should be used only in a pathway-to-pathway relative comparison rather than as absolute values. 
Table B-4. Preliminary Fatality and Injury Rates per Worker

\begin{tabular}{|c|c|c|c|c|}
\hline $\begin{array}{l}\text { Fuel cycle } \\
\text { process }\end{array}$ & $\begin{array}{l}\text { Analogous } \\
\text { US Industry } \\
\text { and } \\
\text { employee } \\
\text { count }\end{array}$ & $\begin{array}{c}\text { Suggested } \\
\text { US Industry } \\
\text { Occupational } \\
\text { Injury rate per } \\
\text { worker per year }\end{array}$ & $\begin{array}{c}\text { Suggested } \\
\text { US Industry } \\
\text { Occupational } \\
\text { Fatality rate per } \\
\text { worker per year }\end{array}$ & $\begin{array}{l}\text { O'Donnell AEC data } \\
\text { from 1973-1974, } \\
\text { Injury and Fatality } \\
\text { rates per } \\
\text { worker per year }\end{array}$ \\
\hline $\begin{array}{l}\text { ISL } \\
\text { mining }\end{array}$ & $\begin{array}{l}\text { Oil \& gas } \\
\text { extraction } \\
337,000\end{array}$ & 0.034 & $2.1 \mathrm{E}-04$ & $\begin{array}{l}0.076 \text { and } 1.23 \mathrm{E}-03 \\
\text { note: for underground } \\
\text { mining }+ \text { milling }\end{array}$ \\
\hline $\begin{array}{l}\text { Trans- } \\
\text { porting } \\
\text { materials }\end{array}$ & $\begin{array}{l}\text { Trucking } \\
1,854,000 \\
\end{array}$ & 0.068 & $1.9 \mathrm{E}-04$ & 0.082 and $6.1 \mathrm{E}-04$ \\
\hline $\begin{array}{l}\text { Yellow } \\
\text { cake } \\
\text { conversio } \\
\mathrm{n}\end{array}$ & $\begin{array}{l}\text { Manufac- } \\
\text { turing } \\
\text { organic } \\
\text { chemicals } \\
118,000\end{array}$ & 0.022 & $2.5 \mathrm{E}-05$ & 0.024 and $1.4 \mathrm{E}-04$ \\
\hline $\begin{array}{l}\text { UF6 } \\
\text { enrich- } \\
\text { ment }\end{array}$ & $\begin{array}{l}\text { Gas } \\
\text { production } \\
\text { and } \\
\text { distribution } \\
124.000\end{array}$ & 0.034 & $4.8 \mathrm{E}-05$ & 0.0013 and $2.3 \mathrm{E}-05$ \\
\hline $\begin{array}{l}\text { Fuel pellet } \\
\text { fabrication }\end{array}$ & $\begin{array}{l}\text { Manufac- } \\
\text { turing } \\
\text { inorganic } \\
\text { chemicals } \\
96,000 \\
\text { and } \\
\text { Manufac- } \\
\text { turing } \\
\text { electronic } \\
\text { components } \\
\text { and } \\
\text { accessories } \\
647,000\end{array}$ & $\begin{array}{c}0.028 \\
\text { and } \\
0.031 \\
\text { total }= \\
0.059\end{array}$ & $\begin{array}{l}5.2 \mathrm{E}-05 \\
\text { and } \\
1.1 \mathrm{E}-05 \\
\text { total }= \\
6.3 \mathrm{E}-05\end{array}$ & 0.0055 and $3.4 \mathrm{E}-05$ \\
\hline $\begin{array}{l}\text { Power } \\
\text { plant } \\
\text { operation, } \\
\text { fuel usage }\end{array}$ & $\begin{array}{l}\text { From nuclear } \\
\text { industry data }\end{array}$ & 0.0022 & $7.0 \mathrm{E}-06$ & $\begin{array}{l}0.0078 \text { and } 1 \mathrm{E}-04 \\
\text { note: } L W R \text { values }\end{array}$ \\
\hline $\begin{array}{l}\text { Spent fuel } \\
\text { storage }\end{array}$ & $\begin{array}{l}\text { Direct data } \\
\text { estimate, no } \\
\text { analogy }\end{array}$ & -- & $1.72 \mathrm{E}-05$ & (not included) \\
\hline
\end{tabular}




\section{Appendix B References}

Benedict, 1957. M. Benedict and T. H. Pigford, Nuclear Chemical Engineering, McGraw-Hill Book Company, New York (1957) chapter 5.

BLS, 1967. Work Injury Experience in Atomic Energy 1965 and 1966, BLS Report 334, PB 227 527, Bureau of Labor Statistics, Washington DC, 1967.

BLS, 1969. Work Injuries in Atomic Energy, 1967, BLS Report 359, PB 227 524, Bureau of Labor Statistics, Washington DC, December 1969.

BLS, 1970. Work Injuries in Atomic Energy, 1968, BLS Report 378, PB 227 540, Bureau of Labor Statistics, Washington DC, 1970.

BLS, 1971. Work Injuries in Atomic Energy, 1969, BLS Report 385, PB 227 528, Bureau of Labor Statistics, Washington DC, 1971.

BLS, 1972. Work Injuries in Atomic Energy, 1970, BLS Report 411, Bureau of Labor Statistics, Washington DC, 1972.

Burrows, 2002. S. Burrows and D. A. Hagemeyer, Occupational Radiation Exposure at Commercial Nuclear Power Reactors and Other Facilities, 2001, thirty-fourth annual report, NUREG-0713, Volume 23, US Nuclear Regulatory Commission, Washington DC, September 2002.

Cadwallader, 2001. L. C. Cadwallader, "Trip Notes from the Visit to Micron Technologies on July 18, 2001,” unpublished document, July 30, 2001.

Cochran, 1999. R. G. Cochran and N. Tsoulfanidis, The Nuclear Fuel Cycle: Analysis and Management, second edition, American Nuclear Society, La Grange Park, Illinois (1999).

EIA, 2003. Uranium Industry Annual 2002, DOE/EIA-0478(2002), US Department of Energy, Energy Information Administration (May 2003). This report is available at http://www.eia.doe.gov/fuelnuclear.html.

Eide, 2003. S. A. Eide and T. E. Wierman, Environment, Safety, and Health Risk Assessment Program (ESHRAP), INEEL/EXT-02-00181, Idaho National Engineering and Environmental Laboratory (December 2003).

FOP, 2002. Fundamentals of Petroleum, Naval Education and Training Command, Books for Business, New York (2002) chapter 4.

Fullwood, 2000. R. R. Fullwood, Probabilistic Safety Assessment in the Chemical and Nuclear Industries, Butterworth Heinemann, Boston (2000) chapter 11. 
INPO, 2003. 2002 Performance Indicators for the U.S. Nuclear Industry, Institute of Nuclear Power Operations, Atlanta, GA, 2003.

Murray, 1994. R. L. Murray, Understanding Radioactive Waste, fourth edition, Battelle Press, Columbus, Ohio (1994).

NN, 1981. S. Rippon, "Comparison of comparative risks," Nuclear News, 24, February 1981, pages 58-60.

NN, 2001. "Statistics show U.S. Nuclear plants always improving," Nuclear News, 44 (May 2001), pages 38-40.

NRC, 1997. Individual Plant Examination Program Perspectives on Reactor Safety and Plant Performance, NUREG-1560, volumes 1-5, US Nuclear Regulatory Commission, Washington, DC (December 1997).

NRC, 2002. Perspectives Gained from the Individual Plant Examination of External Events (IPEEE) Program, NUREG-1742, US Nuclear Regulatory Commission, Washington, DC (April 2001).

NRC, 2002a. "138 kV Ground Protection Trip Results in Auto Start of Emergency Diesel Generators," Licensee Event Report 2002-003, docket number 05000247, October 11, 2002.

O’Donnell, 1981. F. R. O’Donnell and H. C. Hoy, Occupational Safety Data and Casualty Rates for the Uranium Fuel Cycle, ORNL-5797, Oak Ridge National Laboratory (October 1981).

Ramsey, 1998. C. B. Ramsey and M. Modarres, Commercial Nuclear Power, assuring safety for the future, John Wiley \& Sons, Inc., New York (1998) chapter 5.

Slaper, 1998. H. Slaper and R. Blaauboer, "A probabilistic risk assessment for accidental releases from nuclear power plants in Europe," Journal of Hazardous Materials, 61 (1998) 209-215.

Stover, 1997. D. E. Stover, "Smith Ranch, North America's newest ISL uranium mine," Mining Magazine (October 1997) pp. MNA-1 to MNA-8.

Vesterlund, 1998. G. Vesterlund and S. Junkrans, "Perspectives on LWR Fuel Development," Twenty-third Annual Symposium of the Uranium Institute, September 10-11, 1998, London, United Kingdom. Available at internet address: www.world-nuclear.org/sym/1998/pdfs/vest.pdf.

WANO, 2004. 2003 Performance Indicators, World Association of Nuclear Operators, London, UK, June 2004, available at their web site, http://www.wano.org/. 
Wilson, 1996. P. D. Wilson, The Nuclear Fuel Cycle, from Ore to Waste, Oxford University Press, Oxford, United Kingdom (1996). 
Appendix C.

Radiological Protection When Handling Minor Actinides for Nuclear Fuel 


\title{
Radiological Protection When Handling Minor Actinides for Nuclear Fuel
}

\author{
L, C. Cadwallader
}

Introduction. A question has been raised about the means to safely handle fuel materials for nuclear fuels incorporating minor actinides. The methods employed to protect personnel when handling radioactive materials are commensurate with the radioactive decay energy, intensity and type of radiation. The approaches may be classified as a) contact handling, b) ventilation control, c) sealed enclosures, d) semi-remote handling, and e) remote handling. The first three approaches allow human handling directly, usually wearing gloves and perhaps using simple tools (i.e., tongs, forceps). Very weak radiation sources of low specific activity, such as natural uranium, are handled by hand contact in well ventilated areas, either open areas of mill buildings, process facilities, or well-ventilated lab rooms. Small amounts of alpha particle emitters can be handled in fume hoods that provide ventilation control. As radiation levels increase, then sealed enclosures, such as gloveboxes, are used. These provide excellent alpha particle protection and some protection against low energy gamma and x-ray radiation. Shielded gloveboxes and leaded gloves provide higher protection against gamma and x-ray radiation. As the gamma and/or x-ray radiation intensity increases, these design features are insufficient radiological protection (Shuck, 1966). At that point, "semi-remote" equipment, such as in-glovebox tongs and manipulators can be used to reduce radiological exposure (NE, 1962), although these reduce dexterity, thereby increasing exposure time for completing the task. High energy radiation sources require thick shielding walls or a considerable distance from the source to the operator to reduce radiation levels to safe values. The high energy radiation sources are handled using electrically or mechanically controlled remote equipment, operated from remote stations. This increasing personnel protection comes with penalties - for example, using a factor of one to define the time to carry out an operation on an open lab bench with low-activity materials, then in-hood work is about 1.2, glovebox work is in the 1.5 to 3 range, and hot cell operations are 3 to an indefinite upper range (Stewart, 1981).

These pages will set practical limits on transitions between these five methods of personnel protection.

Contact handling. Cember (1996) states that handling radioactive materials in a laboratory room begins with a separated area of the lab room, on a benchtop. Cember states that if the material has a low radiation level and cannot release a gas, vapor or aerosol in a quantity exceeding one Annual Limit on Intake (ALI), then handling with open trays on benchtops allows adequate safety. Actual exposure to ALI inhalation values over a year result in a committed effective dose equivalent of 5 rem. The ALIs have been set by the International Commission on Radiological Protection (ICRP) and are also specified in the US Code of Federal Regulations (CFR, 2004) for a variety of radioactive materials; the ALI value for the given actinide radionuclides of interest here are generally in the 'small fraction of a microcurie' range. The actinides of concern are all classified as 'very high radiotoxicity' (IAEA, 1973). If the emitted radiation could result in a measurable external dose, then additional precautions of portable shielding and 
tongs or reach tools can be used to reduce occupational exposure. Cember implies that no special ventilation control beyond that for a typical laboratory space is needed at $<1$ ALI for materials that do not release gas, vapor or aerosol. Considering that the US Department of Energy (DOE) has also set an Administrative Control Level (ACL) of $0.5 \mathrm{rem} /$ year effective dose equivalent (DOE, 2004), then the ALI would be reduced from 1 ALI at 5 rem to 0.1 ALI at $0.5 \mathrm{rem}$. Other DOE regulations state that general occupancies shall be designed for radiation exposure as low as reasonably achievable (ALARA) and maintained at radiation levels below $0.5 \mathrm{mrem} / \mathrm{h}$ for 2,000 hour work years (CFR, 2002), or 1 rem/year exposure.

Ventilation control. Cember (1996) stated that if the radioactive material can release gas, vapor or aerosol in the range of 1 to $10 \mathrm{ALI}$, the usual practice is to use a fume hood to provide for radiological protection. Considering the US DOE limitations, the lower limit would be less than 0.1 ALI. The IAEA (1981) more generously recommended a range for fume hood work with radium, plutonium, and americium of 10 microcuries to 1 millicurie. The IAEA did have a qualifier that if the dry box work was dusty, then the limit would be 0.1 microcurie to 0.01 millicurie (this would be on the order of $\sim 10$ to 1000 ALI for most actinide nuclidess). The fume hood sweeps the radioactive material release with the air drawn in to the hood, removing the inhalable material from the worker's breathing zone. The fume hood may filter its releases, but gas and vapor are not easily captured, and there is high air flow to treat. Also, fume hoods are susceptible to air flow issues, such as those created by the person standing in front of the sash, quick hand movements in and out of the hood, placement of room air ventilation ducts too close to the hood, and people walking past the hood passing too close to the front of the hood thus creating eddies that could allow the release of small amounts of airborne material out of the hood.

Sealed enclosures. If the radioactive material is over $10 \mathrm{ALI}$, or large amounts of air flow for a hood are not available or practical in the laboratory (Cember, 1996), or there is an environmental protection reason to confine/contain rather than dilute, disperse and vent the material, or an inert atmosphere is needed for material purity or safety, then the glovebox enclosure is the next engineering solution. The IAEA (1981) recommended moving to the glovebox at over 1 millicurie of $\mathrm{Ra}, \mathrm{Pu}, \mathrm{Am}$, etc. The same qualifier from the fume hood discussion was given; if the work was dry and dusty then the transition limit would be 0.01 millicurie. This is on the order of 1,000 ALI for most actinides. The glovebox is a complete enclosure that allows workers to manipulate radioactive and hazardous materials with their hands, using flexible gloves - without high exposure to themselves or unfiltered release of material to the environment. The glovebox is capable of modest differential pressure and may use air, inert gas, or vacuum as an atmosphere. The glovebox may serve multiple functions - it can protect workers from exposure, protect the environment from material release, and it may protect the process material from air and humidity as well (DOE, 2003). Gloveboxes, gloves, and their windows work well to shield against alpha particles and low energy beta particles. Early in the exploration of nuclear energy, gloveboxes were a trademark of the nuclear industry and were considered to be good protection against alpha radiation (Ferguson, 1964). There is 
no longer an industry monopoly on gloveboxes; various types are now used in medical, life science, pharmaceutical, semiconductor manufacturing, and other industries.

An unshielded glovebox can be used for handling 'low exposure' plutonium (10 w/o Pu240, 0.9 w/o Pu-241, balance $\mathrm{Pu}-239$ ) up to the criticality mass limit of a dry process glovebox, which can be kilograms (Louwrier, 1976). Uranium and plutonium are low specific activity elements with low spontaneous fission rates. Their main radiological hazard is inhalation of these low solubility (long term lung retention) alpha particle emitters.

Semi-remote enclosures. If the radioactive material over 10 ALI emits penetrating radiation (e.g., gamma rays or energetic beta particles), then the glovebox steel walls, gloves, and windows may not provide adequate dose protection to the glovebox worker. In the past, the US DOE design guidance was to consider use of remote handling equipment when exposures to the hands and forearms would approach yearly limits, or where contaminated puncture wounds could occur; appropriate shielding was required to minimize radiation to the skin and eyes (DOE, 1989). That guidance is no longer official, but it is still prudent from ALARA considerations.

Consider the example of an isolation glovebox used for removing actinides from irradiated plutonium samples (Schuman, 1957). The sample contained about 20 Curies of beta/gamma actinide activity and 1 Curie of alpha activity. The glovebox had 9-inch steel shielding on four sides but plexiglass walls in front and on top. Through-wall manipulators and tongs penetrated the plexiglass sides to conduct the separations work. In processing the sample ( $\sim 1$ day), operators each received $200 \mathrm{mrem}$. Such a dose would not be allowed any longer in the US DOE complex. The dose could have been reduced by additional precautions of front face shielding, but the implication is clear that $1 \mathrm{E}+01$ Curie levels of actinides pose radiation exposure concerns in gloveboxes.

The federal annual limit for worker dose in the US DOE is 5 rem effective dose equivalent, with 15 rems for the lens of the eye, the sum of deep dose equivalent for external exposure plus committed dose equivalent to organs or tissues must be under 50 rems, and a shallow dose to the skin and extremities also has a limit of 50 rems (CFR, 2002). However, in a standard the US DOE also states that a limit of $2 \mathrm{rem} /$ year is feasible and approval from a DOE Secretarial Officer is required to exceed that level. Furthermore, the US DOE has also set an Administrative Control Level (ACL) of $0.5 \mathrm{rem} /$ year effective dose equivalent "As a challenging and achievable goal for personnel exposure in facilities" (DOE, 2004). Some level of ACL has been adopted at national laboratories and other DOE-operated facilities; for example, the INL uses $700 \mathrm{mrem} /$ year as an ACL (INL, 2005). The INL does not have an ACL for extremities, the $50 \mathrm{rem} /$ year is used for extremity dose. For a new facility, taking $500 \mathrm{mrem} / \mathrm{year}$ as the ACL and using a typical 2,000-hour work year, a maximum dose of $0.25 \mathrm{mrem} / \mathrm{h}$ is allowable. The radiation protection ALARA considerations call for whatever reductions are possible from that average dose. 
If the material above 10 ALI emits gamma radiation that can penetrate the box walls, or beta radiation that can penetrate the windows and gloves, or neutrons that can penetrate any of the glovebox materials, then the glovebox can be fitted with radiation shielding to provide personnel radiological protection. The IAEA (1981) stated that shielded gloveboxes can accommodate radioactive materials in the millicurie to thousands of Curies range, but cautioned that this span was highly dependent on the energy of gamma rays emitted. Strong gammas produce too much exposure to allow hands-on work. As an initial assumption, the range was set as 10 to 1,000,000 ALI. For some actinides, $1 \mathrm{E}+06 \mathrm{ALI}$ is still millicuries, while for some others it is multiple Curies. An example of a very heavily shielded glovebox with a $\sim 1 \mathrm{E}+09$ ALI (Nichols, 1963) housed up to 1 gram of $\mathrm{Cm}-244$ (specific activity $=82 \mathrm{Ci} / \mathrm{g}$ ). However, that appears to be a rather high value that was only accommodated by a specialized, highly shielded glovebox. $\mathrm{Cm}$ isotopes that emit neutrons would now be handled in hot cells.

The typical approach to shielding a glovebox is to build a general stainless steel-walled glovebox shell, then layer lead sheets onto the outer walls of the box for gamma shielding, either gluing or clamping the sheets, overlapping and perhaps melt bonding sheets together to reduce radiation streaming, then welding on another thin layer of stainless steel sheet to the glovebox as an outer cover over the lead. As an example, some gloveboxes in the TA-55 plutonium facility at Los Alamos National Laboratory used 0.25 inch-thick lead sheet on a 0.125 inch-thick stainless steel glovebox shell and then a 0.0625 inch-thick stainless steel cover over the lead. The lead sheet does not extend completely to the window frame or the glove port rings, so there are some areas of reduced shielding that allow the potential for radiation streaming in this approach. A thicker window - usually leaded glass rather than lexan - is framed in metal, the frame is gasketed and bolted to the steel shell.

The shielded glovebox design briefly described above is rather standard. However, if the radiation hazard is high, gloveboxes can be built with thicker shielding layers. For example, a glovebox for chemical analysis of radioactive liquids at INL uses $\sim 1$ inch thick shielding. For neutron shielding, a neutron thermalizer may be used (e.g., hydrogenous material such as polyethylene or water) and a neutron absorber such as boron carbide or boral (boron carbide mixed in aluminum) may be sandwiched with the lead used for gamma shielding. The glovebox windows, which may be constructed of lexan or other plexiglass for low radioactivity boxes, are usually lead oxide or lead silicate impregnated silica glass for radiation protection when penetrating radiation is confined in the glovebox. The gloves are 'leaded' by impregnating the glove material (neoprene, hypalon, etc.) with lead oxide powder to give some fraction of a $\mathrm{mm}$ of effective $\mathrm{Pb}$ shielding to the worker's hands, which are closest to the radioactive material. A typical glove is the North (see northsafety.com) lead-loaded hypalon dry box glove with $0.1 \mathrm{~mm} \mathrm{~Pb}$ equivalent for attenuation of soft gammas. The definition of 'soft gamma' varies, but can be assumed to be in the keV range, usually the upper bound of 'soft' is considered to be $200-300 \mathrm{keV}$, and certainly under $0.5 \mathrm{MeV}$. Glove work poses some concerns that are not easily solved: gloves reduce touch sensitivity and dexterity (so there is the chance of glove abrasion, puncture, or damage), gloves can become slippery when wet and operator perspiration in the anti-contamination hand gloves inside 
the glovebox gloves is very uncomfortable. The operator's sense of heat within the glovebox is greatly reduced, and the person may be under strain when operating the glovebox station (e.g., small hands in large gloves, arms in gloveports are poor ergonomic conditions) (Garden, 1962). Selection of leaded versus non-leaded gloves is not always obvious - radiological ALARA considerations must be balanced against glove durability and the extra "in-box" time required by reduced dexterity (Cournoyer, 2004). Leaded gloves tend to have shorter lifetimes than typical gloves (Dodoo-Amoo, 2003) and crack more easily than non-leaded gloves (Carmack, 2005). The designer defines what process or processes are to be carried out in the glovebox and designs the shielding to meet the yearly DOE ACL, plus a safety factor to avoid overexposures. For new facilities, the ACL would probably be $0.5 \mathrm{rem} / \mathrm{year}$.

An important case history of actinide handling in shielded gloveboxes was given by Louwrier (1976). Handling $2.5 \mathrm{~g}$ increments of americium oxide and aluminum powder for cermet pellet batch preparation in a lead shielded glovebox, with leaded gloves and using tongs of $20-\mathrm{cm}$ length to preclude glove contact with the material, resulted in these in-box gamma dose rates and corresponding finger/hand doses:

preparation and blending of powder

separation and weighing

loading powder in can

cold pressing pellets

dimension control, transfer to furnace

discharging furnace, quality control checks

$600 \mathrm{mrem} / \mathrm{h}$
$800 \mathrm{mrem} / \mathrm{h}$
$500 \mathrm{mrem} / \mathrm{h}$
$200 \mathrm{mrem} / \mathrm{h}$
$200 \mathrm{mrem} / \mathrm{h}$

$200 \mathrm{mrem} / \mathrm{h}$
150-200 mrem

400-600 mrem

$300-500 \mathrm{mrem}$

$30-50 \mathrm{mrem}$

$100-150$ mrem

The finger/hand dose to prepare 132 pellets with a total of 27.5 grams of americium oxide was 19.6 rems. This is a significant fraction of the yearly 50 rem allowed for doses to the extremities, especially since only 132 pellets were fabricated. Typical fuel fabrication facilities with $4 \%$ enriched uranium oxide have had worker extremity doses less than $25 \%$ of the annual exposure limit, as measured by finger ring dosimeters (Sanders, 1975). Louwrier's exposure of 19.6 rems is $39 \%$ of the yearly limit. Louwrier (1976) also described some work with gram amounts of americium-curium; a spent isotopic power source, containing $3.3 \mathrm{~g}$ of Am-241 $(10.7 \mathrm{Ci}, \gamma$ dose $=495 \mathrm{mrem} / \mathrm{h}[1 \mathrm{E}+09$ ALI]), $18 \mathrm{mg}$ of Cm-242 (61 Ci, $2.4 \mathrm{mrem} / \mathrm{h}$ dose is $9 \% \gamma$ and $91 \%$ neutron), and $380 \mathrm{mg}$ of $\mathrm{Pu}-238(6.6 \mathrm{Ci}, \gamma$ dose $=30 \mathrm{mrem} / \mathrm{h})$, was separated into constituent elements. The alpha radiation is not described since it was well-shielded. This Am-Cm work was judged to have high gamma radiation despite the low gamma energy, and was placed in a shielded cell with master-slave manipulators on the primary working side and leaded gloves on the opposite side. On the primary side, there was a lead sheet and a watercontaining wall for radiation shielding, and a leaded glass viewing window. The work was performed solely with the manipulators rather than the gloves because of the high dose rate, and resulted in an exposure rate of $<1 \mathrm{mrem} / \mathrm{h}$ to the operators. The cell had an additional $2 \mathrm{~mm}$ thickness of lead shielding applied to the glove side assure future safe handling of Am-243. After that shielding augmentation, a test was performed using 5.7 micrograms of Cf-252 to simulate 1.2 grams of $\mathrm{Cm}-244$. The neutron dose-rate outside the cell on the glove side (through the lead shielding) was $30 \mathrm{mrem} / \mathrm{h}$ and outside on the 
manipulator side (through the water and lead shielding wall) at the front of the cell was $0.4 \mathrm{mrem} / \mathrm{h}$.

This operating experience shows that the hand doses with modest amounts of Am oxide were quite high even with use of $20-\mathrm{cm}$ tongs. Also, as glovebox wall thickness increases with extra shielding, reach into the glovebox (normally $\sim 26$ inches is the design standard, based on the length of a person's arms) is reduced; hence the usability of the glovebox is reduced. Louwrier's experience shows that despite the higher allowable exposure to hands, leaded gloves cannot offer nearly the same level of hand protection as the shielded glovebox walls offer to the body. Although every effort is made to provide shielding protection, and the $50 \mathrm{rem} /$ year extremities limit is not reduced to lower values by other DOE documentation, the leaded gloves at $\sim 0.1 \mathrm{~mm}$ shield thickness do not offer the same level of radiation protection as the thicker lead sheeting clad on the glovebox walls. ALARA considerations for the extremities dose also affect the time operators work with the high Curie levels in shielded gloveboxes. At the Materials and Fuels Complex at INL, in-box work with materials reading over $100 \mathrm{mrem} / \mathrm{h}$ requires the operator to wear finger dosimeter rings to better record the dose to the hands. Working with such a high radiation level is rare at INL and steps are taken preserve ALARA. The staff endeavors to reduce the frequency that the evolutions occur and samples for chemical analysis are often diluted to reduce the radiation level. As an initial assignation, based on the practical operating experience described above, the transition point for moving from a shielded glovebox to a hot cell is on the order of $1 \mathrm{Ci}$, which for some of the actinides would be $1 \mathrm{M}$ ALI, and for higher hazard actinides would be $1 \mathrm{E}+09$ ALI or greater.

Remote handling. As the materials to be handled increase in radioactivity, the glovebox cannot provide adequate radiological protection. The next step is the hot cell, also referred to as a shielded cell or "cave". Basically, a small hot cell is a robust walled glovebox with metal manipulator arms rather than gloves for handling the higher radioactive materials. The hot cell can be designed to accommodate the highest radiation level of material considered in a given process or operation. The radiation source term has been described in the past as some number of "MeV-Curies". The energy of the penetrating radiation is used with the Curie radioactivity measurement to define the shielding needed. Some early hot cells were designed for $100 \mathrm{Ci}$ at $1 \mathrm{MeV}$ gamma energy for analytical chemistry applications, 10,000 to $100,000 \mathrm{Ci}$ at $1 \mathrm{MeV}$ for post irradiation examination work, and up to $1,000,000 \mathrm{Ci}$ at $1 \mathrm{MeV}$ gamma energy for spent fuel handling work. The smallest hot cell facility noted during literature review was the INL Test Reactor Area cell 2, a lightly shielded cell for metallography and photography, was found to provide protection for a maximum of 10 Curies of Co-60 but some walls required temporary shielding for operator protection when operating above 2.5 Curies (Wagner, 1993). In general, the cell wall concrete thickness increases with increasing source term. The typical design practice has been to define the hot cell operator's allowable dose (such as $5 \mathrm{rem} /$ year with 2,000 work hours/year), use a safety factor of 10 on that value, then determine the required concrete shield wall thickness to reduce the penetrating radiation source term to that dose level (Ferguson, 1964). The concrete walls would be several feet thick for hot cells, necessitating use of augmented reach tools. Hot 
cell windows are then designed to provide the same level of protection as the walls (Northrup, 1965). Other design steps were outlined by Long (1978): the floor area and wall thickness would be established based on the process requirements, then the shielding window would be determined so that it offered similar radiological shielding as the concrete walls of the same thickness, followed by manipulator equipment selection based on process requirements, area to be covered, heaviest load to be lifted, versatility required, and if an airtight seal was needed at the manipulator wall penetration.

The hot cell viewing windows are multiple panes of lead silicate glass with mineral oil or zinc bromide to allow better optical transmission between panes. Tools are all remote manipulators, which have a reasonable reliability. As an example of manipulator reliability, a data point on metal tape driven units at the Materials and Fuels Complex (MFC) of the INL is given. The hot cell is roughly 30 years old that has 21 left-right manipulator stations, and at any given time there may be three individual manipulators down for maintenance due to broken drive tapes or other problems. Tape slippage from a pulley and tape breakage are two of the most common problems of manual manipulator units (Smith, 1957). Considering work on a two-manipulator station basis, with three manipulators down at different stations, such faults give a $14 \%$ outage rate for the mature equipment, or $86 \%$ availability of the hot cell between maintenance outages to repair the manipulators. The design of the MFC hot cell is such that if the center of the cell is handling a $1,000 \mathrm{rem} / \mathrm{h}$ object, the inside wall is exposed to $\sim 100 \mathrm{mrem} / \mathrm{h}$, and the operators at manipulator stations are typically exposed to less than $0.1 \mathrm{mrem} / \mathrm{h}$ (Houser, 2005).

Likar (1988) pointed out that defense high level waste to be remotely handled at the Waste Isolation Pilot Plant would have canister surface dose rates of up to $15,000 \mathrm{rem} / \mathrm{h}$. The hot cell purpose is to unpack canisters of radioactive material from shipping casks, inspect the canisters and overpack any damaged or leaking canisters, place canisters into facility casks for long term storage, and transfer the facility casks to an emplacement machine that places each cask in a position underground. The remote equipment has been designed to tolerate the high dose rate.

Conclusions. Table $\mathrm{C}-1$ gives the suggested radioactivity ranges for moving through the approaches of successive levels of greater protection when handling actinide elements. The transition points given in the table are approximate, but for the multi-gram quantities of actinides to be mixed in to fuel, fully remote hot cell handling is warranted despite the costs of hot cells and the difficulty of handling $4.3-\mathrm{m}$ fuel pins in cells. 
Table C-1. Suggested progression of enclosures for handling radioactive materials

Work environment

level

laboratory benchtop

laboratory fume hood

unshielded glovebox enclosure

shielded glovebox enclosure

hot cell
Level of Radioactivity

Qualitative

$<0.1$ ALI

0.1 to $10 \mathrm{ALI}$

10 to $1,000 \mathrm{ALI}(\mathrm{a})$

10 to $1,000,000 \mathrm{ALI}$

$>1,000,000$ ALI sub-nano to nanocuries

nano to microcuries

micro to millicuries

milli to unity Curies

unity to megacuries

(a) The glovebox may protect at levels greater than 1000 ALI if the emitted radiation is alpha or beta rather than gamma or neutron. If the radiation is penetrating, then a shielded glovebox may need to be used at a small ALI value. 


\section{Appendix C References}

Carmack, 2005. W. J. Carmack, private communication, INL, July 26, 2005.

Cember, 1996. H. Cember, Introduction to Health Physics, third edition, McGraw Hill Book Company, New York, 1996, chapter 11.

CFR, 2002. "Occupational dose limits for general employees," 10CFR835.202, and "Facility design and modifications," 10CFR835.1002, February 4, 2002.

CFR, 2004. "Annual Limits on Intake (ALIs) and Derived Air Concentrations of Redionuclides for Occupational Exposure; Effluent Concentrations; Concentrations for Release to Sewerage", 10CFR20, Appendix B, January 1, 2004.

Cournoyer, 2004. M. E. Cournoyer et al., "Minimizing Glovebox Glove Breaches," Enclosure, 17, number 2 (2004) 6-21.

Dodoo-Amoo, 2003. D. N. Dodoo-Amoo et al., "Development of Composite Materials for Non-Leaded Gloves for Use in Radiological Hand Protection," Health Physics, 84 (2003) 737-746.

DOE, 1989. General Design Criteria, DOE 6430.1A, US Department of Energy, April 6, 1989, page 13-9.

DOE, 2003. Air Cleaning Handbook, DOE HDBK-1169-2003, US Department of Energy, 2003, chapter 7 .

DOE, 2004. Radiological Control, DOE-STD-1098-99, US Department of Energy, reaffirmed December 2004.

Ferguson, 1964. K. R. Ferguson, W. B. Doe, and R. C. Goertz, "Remote Handling of Radioactive Materials," in S. McLain and J. H. Martens, Reactor Handbook, Volume IV, Engineering, John Wiley Interscience, New York, 1964, chapter 14.

Garden, 1962. N. B. Garden, Report on Glove Boxes and Containment Enclosures, TID16020, US Atomic Energy Commission, June 1962, appendix III.

Houser, 2005. H. A. Houser, private communication, INL, August 2, 2005.

IAEA, 1973. Safe Handling of Radionuclides, 1973 Edition, IAEA Safety Series No. 1, International Atomic Energy Agency, Vienna, March 1973. 
IAEA, 1981. Manual on Safety Aspects of the Design and Equipment of Hot Laboratories, IAEA Safety Series No. 30, International Atomic Energy Agency, Vienna, 1981.

INL, 2005. Radiological Worker Training Student Guide, revision 6, Idaho National Laboratory, July 2005, page 3-27.

Likar, 1988. V. F. Likar, "Remote Handling System for Waste at the Waste Isolation Pilot Plant," Proceedings of the $35^{\text {th }}$ Conference on Remote Systems Technology, Los Angeles, California, November 1987, American Nuclear Society, 1988, pages 45-48.

Long, 1978. J. T. Long, Engineering for Nuclear Fuel Reprocessing, American Nuclear Society, 1978, chapter 11.

NE, 1962. "Handling Radioactive Materials," Nuclear Engineering, 7 (June 1962) 224238.

Nichols, 1963. J. P. Nichols et al., "Evaluation of Shielding and Hazards in the Transuranium Processing Plant," Nuclear Science and Engineeirng, 17 (1963) 486-491.

Northrup, 1965. T. E. Northrup, "A Gam-Neu Viewing Window Design," Nuclear Structural Engineering, 1 (165) 108-117.

Sanders, 1975. C. F. Sanders and R. D. Bibb, "Industrial Fuel Fabrication Operation," Conference on Occupational Health Experience with Uranium, ERDA-93, US Energy Research and Development Administration, 1975, pages 195-203.

Schuman, 1957. R. P. Schuman and M. E. Jones, "A Small, Steel-shielded Isolation Box for Chemical Experiments," Proceedings of the Fifth Hot Laboratories and Equipment Conference, 1957 Nuclear Congress, March 14-15, 1957, Philadelphia, Pennsylvania, 1957, pages 128-132.

Shuck, 1966. A. B. Shuck, A. L. Lotts, and K. Drumheller, "The Remote Fabrication of Reactor Fuels," in L. E. Link, editor, Reactor Technology, Selected Reviews 1965, TID-8541, US Atomic Energy Commission, January 1966, pages 71-148.

Smith, 1957. S. C. Smith, "Remote Manipulation Maintenance," Proceedings of the Fifth Hot Laboratories and Equipment Conference, 1957 Nuclear Congress, March 1415, 1957, Philadelphia, Pennsylvania, pages 67-72.

Stewart, 1981. D. C. Stewart, Handling Radioactivity, A Practical Approach for

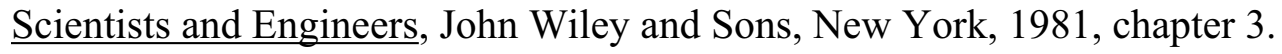


Wagner, 1993. W. D. Wagner, TRA Hot Cell 2 Shielding Evaluation for Safe Operating Basis, engineering design file TRA-HC-796, Idaho National Engineering Laboratory, October 1993. 
Appendix D.

Safety and Reliability Issues in Fabrication of Recycle Nuclear Fuel 


\title{
SAFETY AND RELIABILITY ISSUES IN FABRICATION OF RECYCLE FUEL
}

\author{
L. Cadwallader
}

Introduction. A question has been posed in the Advanced Fuel Cycle Initiative (AFCI) about using recycled uranium fuel with the addition of actinide wastes in reactors so that the excess neutrons in the reactor core will fission or transmute the actinide wastes in the recycled fuel. With the consumption of the long-lived actinides placed into recycle fuel, then there is less high level waste to store in an underground repository. This paper examines several safety and reliability issues of fabricating new fuel pellets and assemblies with the addition of the minor actinides in the uranium fuel.

Background. In the present uranium fuel cycle in the United States, the "fresh" fuel originating from uranium mines and enrichment for reactor use is composed mainly of $U$ $238, \sim 5 \%$ of U-235, and $\sim 0.04 \%$ U-234 (Rice, 1994). Therefore, with these long-lived radionuclides, the fuel is low specific activity. It is a low radiological hazard and has low dose rates. Table D-1 gives the radioactivity of unirradiated uranium dioxide fuel. The typical safety precautions in a fuel fabrication facility are mainly for laboratory-type cleanliness. Gloves are worn to protect hands from surface contamination and to keep skin oils, skin cells, etc., from the fuel. Hats or caps might be worn to prevent hairs from getting into the process, and lab coats are worn to protect against contamination of clothing and from clothing contamination of the fuel. General area ventilation is used in portions of the fabrication buildings where the uranium is in solid form. When handling uranium dioxide in powder form for individual fuel pellet manufacture, gloveboxes and respirators are used to prevent inhalation of fuel particles and control contamination by fuel dust. Uranium is a heavy metal, and most heavy metals have some level of chemical toxicity when inhaled (Klaassen, 2001; ATSDR, 2004; ATSDR, 1990; ATSDR, 1999). Heavy metals are generally not soluble in water and do not clear from the lungs easily when inhaled. While their radioactivity is low, these are alpha particle emitters. Depositing alpha particle energy in the lungs is very damaging.

Typically, meeting the 10CFR20.1201 occupational dose limit of $5 \mathrm{rem} / \mathrm{year}$ in the existing "once-through" fuel fabrication plants is not difficult if inhalation of dust is precluded. These plants use gloveboxes for dusty operations and ventilation control in other portions of the fuel fabrication line (Brodsky, 1985).

If uranium is recycled and some of the actinide elements are included in the recycled fuel, then concentrations of more highly radioactive elements will be present. Table D-2 lists the actinides from irradiated uranium fuel (Benedict, 1981). Note in Table D-2 that most of the principal decay modes are alpha particles, often in the $5 \mathrm{MeV}$ range, accompanied by low energy gamma emission, with a few isotopes decaying by beta particles emission. Also note the annual limits on intake (ALIs) for airborne matter are also in the microCurie range for nearly all of these isotopes. 
Table D-1. Uranium radioactivity

\begin{tabular}{|c|c|c|}
\hline Isotope & half-life (yrs) & principal decay \\
\hline U-238 & $4.47 \mathrm{E}+9$ & alpha at $\sim 4.1 \mathrm{MeV}$ \\
\hline U-235 & $7.04 \mathrm{E}+8$ & alpha at $\sim 4.4 \mathrm{MeV}$ \\
\hline U-234 & $2.46 \mathrm{E}+5$ & alpha at $\sim 4.7 \mathrm{MeV}$ \\
\hline
\end{tabular}

Uranium chemical toxicity as a carcinogenic heavy metal is:

$\begin{array}{lll}\text { NIOSH }= & 0.20 \mathrm{mg} / \mathrm{m}^{3} & \text { NIOSH IDLH }=10 \mathrm{mg} / \mathrm{m}^{3} \text { as U } \\ \text { OSHA }= & 0.25 \mathrm{mg} / \mathrm{m}^{3} & \\ \text { ACGIH }= & 0.2 \mathrm{mg} / \mathrm{m}^{3} & \\ \text { AIHA }= & \text { not listed } & \end{array}$

These values are for $\mathrm{U}$ and insoluble compounds, the listed mass as $\mathrm{U}$. The high density of uranium means that dust must be suppressed or confined to meet the $\sim 0.2 \mathrm{mg}$ level.

note: specific activity of natural uranium $(0.72 \%$ by weight $\mathrm{U}-235)$ is $\sim 7.1 \mathrm{E}-07 \mathrm{Ci} / \mathrm{gram}$ and for $5 \%$ enriched uranium the specific activity is $\sim 2.6 \mathrm{E}-06 \mathrm{Ci}$ /gram (from 10CFR71, Table A-4). These are low specific activity mixtures of uranium; protection must be provided to not inhale these alpha-particle emitters but otherwise they are not particularly dangerous to handle.

The existing fuel fabrication processes would have to be enhanced with radiation protection if the "minor actinides' of americium, neptunium, and especially curium were included in recycled fuel. There is some experience in the world with mixed oxide (MOX) fuel fabrication, where the chemical and radioactive toxicity of plutonium required confinement. Glovebox lines are typically used in MOX fuel fabrication plants because of the chemical and radiotoxicity of plutonium. There has also been some work with reprocessed uranium. The experiences of this work have been surveyed to find any reliability or safety issues that should be addressed as the US considers the idea of fuel fabrication with reprocessed uranium.

There are several issues addressed here. These include the differences between typical fuel fabrication presently performed and the inclusion of actinide elements in the handling process. The main differences are radiation and chemical composition. Each of these is addressed below. 
Table D-2. Actinide element radioactivity

\begin{tabular}{|c|c|c|c|c|c|}
\hline Isotope & $\begin{array}{l}\text { Half-life } \\
\text { (years) }\end{array}$ & Principal decay mode & $\begin{array}{l}\text { Decay } \\
\text { product }\end{array}$ & $\begin{array}{l}\text { Specific } \\
\text { activity } \\
(\mathrm{Ci} / \mathrm{g})\end{array}$ & $\begin{array}{l}\mathbf{A L I} \\
(\mu \mathrm{Ci})\end{array}$ \\
\hline $\mathrm{Np}-237$ & $2.14 \mathrm{E}+06$ & $100 \%$ alpha at $\sim 4.7 \mathrm{MeV}$ & $\mathrm{Pa}-233$ & $7 \mathrm{E}-04$ & 5E-01 \\
\hline $\mathrm{Np}-238$ & 2.117 days & $100 \%$ beta at $0.26 \mathrm{MeV}$ & $\mathrm{Pu}-238$ & $2.6 \mathrm{E}+05$ & $2 \mathrm{E}+03$ \\
\hline $\mathrm{Pu}-236$ & 2.87 & $\begin{array}{l}\sim 100 \% \text { alpha at } \sim 5.7 \mathrm{MeV} \\
\mathrm{SF}=3.39 \mathrm{E}+04 \mathrm{n} / \mathrm{s}-\mathrm{g}\end{array}$ & $\mathrm{U}-232$ & 527 & $2 \mathrm{E}-02$ \\
\hline $\mathrm{Pu}-238$ & 87.7 & $\begin{array}{l}\sim 100 \% \text { alpha at } \sim 5.4 \mathrm{MeV} \\
\mathrm{SF}=2.588 \mathrm{E}+03 \mathrm{n} / \mathrm{s}-\mathrm{g}\end{array}$ & U-234 & 17 & $7 \mathrm{E}-03$ \\
\hline $\mathrm{Pu}-239$ & $2.41 \mathrm{E}+04$ & $100 \%$ alpha at $\sim 5.1 \mathrm{MeV}$ & U-235 & 0.06 & $6 \mathrm{E}-03$ \\
\hline $\mathrm{Pu}-240$ & $6.56 \mathrm{E}+03$ & $\begin{array}{l}\sim 100 \% \text { alpha at } \sim 5.1 \mathrm{MeV} \\
\mathrm{SF}=9.087 \mathrm{E}+02 \mathrm{n} / \mathrm{s}-\mathrm{g}\end{array}$ & U-236 & 0.23 & $6 \mathrm{E}-03$ \\
\hline $\mathrm{Pu}-241$ & 14.4 & $99 \%$ beta at $20 \mathrm{keV}$ & Am-241 & 110 & $3 \mathrm{E}-01$ \\
\hline $\mathrm{Pu}-242$ & $3.75 \mathrm{E}+05$ & $\begin{array}{l}\sim 100 \% \text { alpha at } \sim 4.8 \mathrm{MeV} \\
\mathrm{SF}=1.718 \mathrm{E}+03 \mathrm{n} / \mathrm{s}-\mathrm{g}\end{array}$ & U-238 & $4 \mathrm{E}-03$ & $2 \mathrm{E}-02$ \\
\hline Am-241 & 432.7 & $100 \%$ alpha at $\sim 5.4 \mathrm{MeV}$ & $\mathrm{Np}-237$ & 3.2 & $6 \mathrm{E}-03$ \\
\hline Am-242 & 16 hours & $\begin{array}{l}82.7 \% \text { beta at } 0.18 \mathrm{MeV} \\
17.3 \% \text { electron capture }\end{array}$ & $\begin{array}{l}\mathrm{Cm}-242 \\
\mathrm{Pu}-242\end{array}$ & $8.1 \mathrm{E}+05$ & $8 \mathrm{E}+01$ \\
\hline $\mathrm{Am}-242 \mathrm{~m}$ & 152 & $\begin{array}{l}\sim 99.5 \% \text { gamma at } 0.04 \mathrm{Me} \\
\mathrm{SF}=1.247 \mathrm{E}+02 \mathrm{n} / \mathrm{s}-\mathrm{g}\end{array}$ & Am-242 & 9.7 & $6 \mathrm{E}-03$ \\
\hline Am-243 & $7.37 \mathrm{E}+03$ & $100 \%$ alpha at $5.2 \mathrm{MeV}$ & $\mathrm{Np}-239$ & 0.19 & $6 \mathrm{E}-03$ \\
\hline $\mathrm{Cm}-242$ & 162.8 days & $\begin{array}{l}\sim 100 \% \text { alpha at } \sim 6 \mathrm{MeV} \\
\mathrm{SF}=2.10 \mathrm{E}+07 \mathrm{n} / \mathrm{s}-\mathrm{g}\end{array}$ & $\mathrm{Pu}-238$ & 3,400 & $3 \mathrm{E}-01$ \\
\hline $\mathrm{Cm}-243$ & 29.1 & $\begin{array}{l}\sim 99.74 \% \text { alpha at } 5.7 \mathrm{MeV} \\
0.26 \% \text { electron capture } \\
\mathrm{SF}=1.22 \mathrm{E}+03 \mathrm{n} / \mathrm{s}-\mathrm{g}\end{array}$ & $\begin{array}{l}\mathrm{Pu}-239 \\
\mathrm{Am}-243\end{array}$ & 52 & 9E-03 \\
\hline $\mathrm{Cm}-244$ & 18.1 & $\begin{array}{l}\sim 100 \% \text { alpha at } \sim 5.7 \mathrm{MeV} \\
\mathrm{SF}=1.080 \mathrm{E}+07 \mathrm{n} / \mathrm{s}-\mathrm{g}\end{array}$ & $\mathrm{Pu}-240$ & 82 & $1 \mathrm{E}-02$ \\
\hline $\mathrm{Cm}-245$ & $8.5 \mathrm{E}+03$ & $\begin{array}{l}\sim 100 \% \text { alpha at } \sim 5.3 \mathrm{MeV} \\
\mathrm{SF}=3.875 \mathrm{E}+01 \mathrm{n} / \mathrm{s}-\mathrm{g}\end{array}$ & $\mathrm{Pu}-241$ & 0.17 & $6 \mathrm{E}-03$ \\
\hline $\mathrm{Cm}-246$ & $4.76 \mathrm{E}+03$ & $\begin{array}{l}\sim 100 \% \text { alpha at } \sim 5.3 \mathrm{MeV} \\
\mathrm{SF}=9.448 \mathrm{E}+06 \mathrm{n} / \mathrm{s}-\mathrm{g}\end{array}$ & $\mathrm{Pu}-242$ & 0.31 & $6 \mathrm{E}-03$ \\
\hline U-234 & $2.46 \mathrm{E}+05$ & $100 \%$ alpha at $\sim 4.7 \mathrm{MeV}$ & Th-230 & $6.2 \mathrm{E}-03$ & 7E-01 \\
\hline U-235 & $7.04 \mathrm{E}+08$ & $100 \%$ alpha at $\sim 4.4 \mathrm{MeV}$ & Th-231 & $2.1 \mathrm{E}-06$ & $8 \mathrm{E}-01$ \\
\hline U-236 & $2.342 \mathrm{E}+07$ & $100 \%$ alpha at $\sim 4.5 \mathrm{MeV}$ & Th-232 & $6 \mathrm{E}-05$ & $8 \mathrm{E}-01$ \\
\hline U-237 & 6.75 days & $\begin{array}{l}80 \% \text { beta at } 0.24 \mathrm{MeV} \\
40 \% \text { gamma at } 64.5 \mathrm{keV}\end{array}$ & Np-237 & $8.2 \mathrm{E}+04$ & $2 \mathrm{E}+03$ \\
\hline U-238 & $4.47 \mathrm{E}+09$ & $\begin{array}{l}\sim 100 \% \text { alpha at } \sim 4.1 \mathrm{MeV} \\
\mathrm{SF}=1.36 \mathrm{E}-02 \mathrm{n} / \mathrm{s}-\mathrm{g}\end{array}$ & Th-234 & $3.3 \mathrm{E}-07$ & $8 \mathrm{E}-01$ \\
\hline \multicolumn{6}{|c|}{$\begin{array}{l}\text { Table notes: specific activity of natural uranium }(0.72 \% \text { by weight U-235) is } \sim 7.1 \mathrm{E}-07 \mathrm{Ci} / \text { gram and for } 5 \% \text { enriched uranium the specific } \\
\text { activity is } \sim 2.6 \mathrm{E}-06 \mathrm{Ci} / \text { gram (from 10CFR71, Table A-4). These are low specific activity mixtures of uranium; protection must be provided to } \\
\text { not inhale these alpha-particle emitters but otherwise they are not dangerous to handle. } \\
\text { references: Lederer, 1978; Baum, 2002; spontaneous fission values over } 1 \mathrm{E}+01 \text { were cited, values were from report LA-UR-01-5572, } \\
\text { September } 2001 \\
\text { Annual Limits of Intake (ALI) are inhalation values taken from 10CFR20, Appendix B "Annual Limits on Intake (ALIs) and Derived Air Conc } \\
\text { of Radionuclides for Occupational Exposure; Effluent Concentrations; Concentrations for Release to Sewerage", January 1, 2004. ALI values an } \\
\text { of microCuries, and lung clearance class W was selected for consistency when multiple values were listed. }\end{array}$} \\
\hline
\end{tabular}


Issues of Radiation

These alpha emitters, with some low energy gamma emission and a few fairly strong spontaneous fission isotopes (especially $\mathrm{Cm}-242$ and $\mathrm{Cm}-244$ ) present several handling problems (Louwrier, 1976) beyond typical uranium:

decay heat

radiolysis of solutions

radiation damage of solids

personnel exposure

Another issue is that the low energy gammas sometimes emitted by the alpha emitters and perhaps also the alpha particles themselves will interact with oxygen in hot cells. Even if a hot cell or glovebox uses an inert atmosphere (e.g., argon, nitrogen) there can be small amounts of inleakage oxygen since these enclosures operate at slightly negative pressure for particulate contamination control. The maximum permissible oxygen content is suggested to be in the 25 to $50 \mathrm{ppm}$ range (ANS, 1988). The concern with oxygen is molecular dissociation. When oxygen molecules are dissociated, elemental or free radical oxygen atoms are created. These atoms generally recombine quickly with any nearby oxygen molecules to form ozone molecules. In a similar manner, nitrogen molecules can be dissociated, allowing nitrogen radicals to form nitrogen oxides $\left(\mathrm{NO}_{\mathrm{x}}\right)$. Nitric acid $\left(\mathrm{HNO}_{3}\right)$ molecules can also be formed from ozone, oxygen radicals, and atmospheric humidity (Batchelor, 1982). Ozone is chemically very corrosive and is highly detrimental to plastics, such as electrical insulation, sleeves on manipulators, containers, etc., and also to rubber gloves used in gloveboxes. For that reason, hypalon (chloro-sulfonated polyethylene) gloves are favored for their resistance to ozone degradation (Louwrier, 1976). Ozone has also been known to attack metal. Hot cells or automated gloveboxes would need to be monitored for the ppm oxygen concentration. If the oxygen level increased, then there would be concerns about ozone creation and ozone degradation of materials.

Renard (1995) points out that incorporating actinides, especially curium, into a MOX fuel line may not be the best use of the line because of the contamination and retrofitting the line to accommodate the extra radioactivity and criticality concerns. Using americium and curium targets in a reactor core rather than blending these actinides into the fuel have some advantages.

Decay heat. The decay heat given off by actinides is a concern for shielded enclosures since these inert-atmosphere enclosures are not well ventilated and require special provisions to remove heat. A typical hot cell temperature should not exceed $30 \mathrm{C}(86 \mathrm{~F})$ and it is already heated by the intense lighting in the cell (the windows reduce the light intensity by more than half, so the lights must produce high luminosity) and other heat sources, such as motors, friction in machining parts, welders, and other equipment (Wahlquist, 1998). Inert gases may not cool as well as air when it is draw through an electrical motor casing. Electrical equipment is generally favored in hot cells due to the non-contaminating nature of electrical power (versus hydraulic or pneumatic power), but 
keeping electrical equipment cool is an important issue to guarantee reliable operation and long motor lifetimes. Wahlquist (1998) notes some types of motors may not be suitable for the very low humidity gas environment of a hot cell. High temperatures in the glovebox or cell tend to degrade electrical insulation in motors and wiring, reducing the useful life of the equipment, and high temperatures also place demands on lubricants for manipulators and on television cameras that might be in use. High temperatures can degrade gloves and window seals in gloveboxes. Some hot cells have cooling systems, refrigeration systems that allow the in-cell gas or metal parts of a machine to transfer heat to the refrigerant. These are rated to remove some level of kilowatts. If actinides increase the in-cell heating, changes would be needed to bring the temperature back down within normal limits.

Recalling that U-235 is $\sim 1 \mathrm{E}-06$ watts/gram, the specific heat values for several of the actinides of interest are listed below in watts/gram (Ferguson, 1963):

$\begin{array}{ll}\mathrm{Pu}-238 & 0.555 \\ \mathrm{Pu}-240 & 0.007 \\ \mathrm{Pu}-241 & 0.004 \\ \mathrm{Pu}-242 & 0.0001 \\ \mathrm{Am}-241 & 0.106 \\ \mathrm{Am}-242 & 1000 . \\ \mathrm{Am}-242 \mathrm{~m} & 0.003 \\ \mathrm{Am}-243 & 0.006 \\ \mathrm{Am}-244 & 88,000 . \\ \mathrm{Cm}-242 & 122 . \\ \mathrm{Cm}-243 & 1.47 \\ \mathrm{Cm}-244 & 2.91 \\ \mathrm{Cm}-245 & 0.006 \\ \mathrm{Cm}-246 & 0.0072\end{array}$

Obviously, the Cm-242 and Am-242 isotopes have high heat emission that must be dealt with in the design of the facility (Am-244 is very high; however, it is quite rare). Pillon (2003) stated that work with minor actinides would require continuous forced cooling throughout the fabrication facility. Forced cooling would be necessary for the fuel assemblies during pellet loading and pin mounting to keep the long, thin-walled pin structural material temperatures low enough to avoid damage during handling and storage. One possibility to consider was discussed in Weissert (1968); completed fuel pins of Th-232/U-233 were placed into fuel assemblies under water. The fuel element assembling machine operated in a canal for the pilot plant at Oak Ridge National Laboratory.

Radiolysis of solutions. Two materials are added to the powder before compaction. The first material is called 'binder". It is usually a liquid adhesive, added to 'cement' the powder so that the fuel powder handles better for pressing into pellet form in a press. The second material is a lubricant, which is added to allow more positive and uniform compaction of the power in the press. Proper compaction results in a uniform density 
pellet, which is needed for consistent nuclear and thermal properties in the reactor core. There are some materials that can serve as both a binder and lubricant; since the liquid is expelled from the pellet during furnace heating at $\sim 1700 \mathrm{C}$ in the pellet sintering process, the liquid is not an impurity concern. Mobil \#6 motor oil has been used as a combination binder and lubricant in the US (Carmack, 2005). Cochran (1999) stated that a binder sometimes used is polyvinyl alcohol. Alpha particles are short-range radiation, but they are directly adjacent to the binder and lubricant and are energetic enough to affect these materials. When hydrocarbons like alcohol and oil are bombarded with alpha particles, the molecular chains can be broken and they can release smaller hydrocarbons, namely hydrogen and methane. Such gases pose a concern in air filled gloveboxes or hot cells.

Pillon (2003) discussed that for an industrial scale of pellet production, pellet pressing required lubricants, but the minor actinide radioactivity causes the lubricant to break down and lose lubrication properties. The green pellets (the pressed pellets before heating in the sintering furnace) also can become mechanically unstable due to binderlubricant degradation. The proposed solution was to use a separate binder and develop press dies that are automatically lubricated before each pellet rather than adding lubricant to the pellet material. This adds complexity to the machine, but the alternative is to allow fabrication of high numbers of substandard units that must be scrapped. This would mean that some material continues to traverse the fabrication line. Allowing material to "ride the circuit" means extra inventory is present and susceptible to accident events.

Radiation damage. Typically, alpha particles do not create damage in metals, and are too short range to be a concern for windows. Alpha particles may break down the lubricants in manipulators, especially the lube in the end effector joints close to the emitter. There are some concerns for gamma rays and beta radiation emitted by the actinides, although low energy gammas generally do not affect the metal components in hot cells (Wahlquist, 1998). Gamma radiation can have severe damaging effects on lubricants. Another example of a susceptible component in a hot cell is a television camera lens. Feraday (1981) stated that estimated dose rates to cameras in a remote fabrication hot cell would be $<2 \mathrm{rad} /$ hour and this was acceptable for work with thorium-uranium fuels, where U232 has some hard gamma ray emission in its decay chain. If a new facility to handle actinides in fuel is designed, then the radiation to cameras would be accounted for in the design. If an existing facility; that is, a MOX facility, began handling minor actinides, the additional radiation levels must be evaluated for the additional exposures and resulting damage from exposure. The spontaneous fission neutrons are another concern. Overall, robotic equipment in factories has exhibited high reliability in the $97 \%$ availability range (Nof, 1985), but the service lifetime of industrial robots is only 12 to 15 years (UN, 2002). The source documentation did not specify if the 12-15 year lifetime was based on obsolescence or wear out. The Materials and Fuels Complex at the INL has a large hot cell with 21 manipulator stations. The hot cell has operated for over 30 years (Houser, 2005). At any given time, there may be up to three manipulators out of service waiting for maintenance, or 18 operable stations out of a total of 21 stations gives $86 \%$ availability. Since some hot cell equipment has lifetimes of $30+$ years, then perhaps factory retooling for new products and obsolescence are the dominant factors in robot lifetimes. 
Remote manipulator "boots", that is, the sleeve-like covers over the in-cell portion of manipulator tools, are a source of continual concern for cell confinement integrity and contamination control. The boots are actually part of the seal for the manipulator penetration through the thick concrete wall, so they comprise a weak spot in the hot cell confinement boundary. Robinson (1969) stated that small particles of ${ }^{244} \mathrm{Cm}_{2} \mathrm{O}_{3}$ at a curium hot cell facility were capable of burning pinholes through polyurethane boot material. Others noted that boot lifetimes in actinide processing hot cells were on the order of 10 months (Samsel, 1970), meaning annual replacement was standard procedure. Either more resilient materials are needed, or a changeout device is needed to make the boot replacement as quick as possible. If curium particles can damage the manipulator boots, then filters are also at risk. Some method of particle capture is needed ahead of the hot cell's gas filter banks.

Personnel exposure. Roepenack (1987) stated that the low energy gamma radiation of $\mathrm{Pu}$ and Am handled in MOX fabrication was negligible as long as the materials were held in bulky configurations. In bulk configurations there is high self-absorption and selfshielding. When the powders are spread out over widespread areas there is little selfshielding and the low energy gammas can contribute considerably to the glovebox operator's dose rate. The situation would be worse with actinides adding more gammas and also spontaneous fissions to challenge the shielding. Bemden (1981), Leblanc (1982), and Carmack (2005) also stated that dust is known to accumulate in the "powder" section of fuel fabrication lines. The powder section is where the uranium dioxide in a loose powder form is mixed and blended, then compacted into pellet form; this portion of fuel fabrication is always performed in some type of enclosure to control the spread of dust and protect personnel from dust inhalation and radiation exposure from dusts. When there are low energy gamma emitters accumulating with this fuel dust, the increasing radiation level versus a fixed shield wall thickness begins to pose an exposure concern for personnel working in and near the gloveboxes that house the powder section of the fuel fabrication line (Draulans, 1985). In fact, the powder tends to spread everywhere within the enclosure and in general is tedious to clean up (Carmack, 2005). Dust can also accumulate in the filters and ventilation systems of gloveboxes and hot cells. Some of the actinide dusts, especially $\mathrm{Cm}-244$, would be difficult to detect through the shield walls because they have weak gamma emissions, but they pose a significant concern because they emit neutrons from spontaneous fission (Haggard, 1996). Typically, with low specific activity uranium, the dust accumulation concern dwells on criticality rather than radiation exposure. The actinides have relatively high critical mass limits, as shown in Table D-3, the lowest being 13 grams of Am-242m in water. The fabrication processes should be dry, so criticality mass limits are in the kilogram range which should allow reasonable size batches of fuel. The criticality safety "double contingency" precautions of mass limits and geometry/moderator limits have served well in the fuel fabrication industry and would be needed with mixtures of non-fissile and fissile isotopes. Mixtures of oxide materials will need to be addressed for criticality safety issues, especially the spontaneous fission isotopes. The fuel dust would have to be regularly and thoroughly cleaned if gloveboxes are used to house an automated process line for fuel with actinides. Otherwise, any personnel intervention for surveillance or 
maintenance would expose the person to a high dose. Design provisions must be made to remotely decontaminate such gloveboxes.

Pillon (2003) discussed that for curium, powder metallurgy processes that generate dust must be avoided. Direct synthesis of dust-free spherical particles was proposed. Vibrocompaction to form pellets for sintering was suggested. Robinson (1969) discussed that low gas flow was important for reducing curium contamination, but with low gas flow, alternate cooling had to be installed in a curium hot cell. Pillon (2003) discussed the solution-gelation (sol-gel) approach to fuel fabrication. However, alpha particle radiation, especially from curium isotopes, degrades the solution in the sol-gel process. Pillon stated that the process must be performed rapidly to be successful. Based on that information, any unplanned process delays (power outages, equipment tripping off-line, instrument noise, etc.) mean retaining the material in the processing stream longer.

Renard (1997) described that $0.165 \mathrm{~kg}$ of americium oxide in a container gave an equivalent dose $(0.0344 \mathrm{mSv} / \mathrm{h})$ to $13.2 \mathrm{~kg}$ of plutonium oxide in a container. In a MOX facility, the storage cans and storage cavity rooms would need additional shielding if the americium supply increased. As shown in Table 2, Pu-241 decays to Am-241 with a 14year half-life. Therefore, as more Pu-241 is bred, then more Am-241"grows in," increasing the americium quantity. Such increases need to be tracked and addressed, so actinide handling is more complicated than fresh uranium handling. Renard (1995) stated that neptunium recycling could occur without difficulty in existing MOX glovebox lines, that americium would require more shielding for safety, which was costly and cumbersome but feasible, and that curium recycling would give a factor of 100 increase in the neutron source. This increased neutron source would require such thick shielding that it precluded recycle fuel work in existing MOX plants; remote handling was suggested. Renard (1995a) suggested that the limitations in recycle were not in fuel fabrication since hot cells could provide adequate personnel protection, but in the core physics-neutronics issues of placing the actinide blended fuel in the reactor. 
Table D-3. Subcritical mass limits for non-fissile and fissile actinide nuclides

\begin{tabular}{|c|c|c|c|c|}
\hline \multirow[b]{2}{*}{ Nuclide } & \multirow[b]{2}{*}{ Chemical form } & \multicolumn{2}{|r|}{ Mass limit $(\mathrm{kg})$ of nuclide } & \multirow[b]{2}{*}{$\underline{\text { Steel reflector }}$} \\
\hline & & & Water reflector & \\
\hline \multirow[t]{2}{*}{ Np-237 } & $\mathrm{Np}$ & 30 & 20 & \\
\hline & $\mathrm{NpO}_{2}$ & 140 & 90 & \\
\hline \multirow[t]{2}{*}{ Pu-238 } & $\mathrm{Pu}$ & 4 & 3 & \\
\hline & $\mathrm{PuO}_{2}$ & 11 & 7 & \\
\hline \multirow[t]{2}{*}{ Pu-240 } & $\mathrm{Pu}$ & 20 & 15 & \\
\hline & $\mathrm{PuO}_{2}$ & 70 & 45 & \\
\hline $\mathrm{Pu}-242$ & $\mathrm{Pu}$ & 60 & 40 & \\
\hline \multirow[t]{2}{*}{ Am-241 } & $\mathrm{Am}$ & 24 & 16 & \\
\hline & $\mathrm{AmO}_{2}$ & 40 & 32 & \\
\hline \multirow[t]{3}{*}{ Am-243 } & $\mathrm{Am}$ & 35 & 25 & \\
\hline & $\mathrm{Am}_{2} \mathrm{O}_{3}$ & 50 & 37 & \\
\hline & $\mathrm{AmO}_{2}$ & 60 & 45 & \\
\hline \multirow[t]{3}{*}{$\mathrm{Cm}-244$} & $\mathrm{Cm}$ & 5 & 3 & \\
\hline & $\mathrm{Cm}_{2} \mathrm{O}_{3}$ & 7 & 5 & \\
\hline & $\mathrm{CmO}_{2}$ & 7 & 5 & \\
\hline Pu-239 & $\mathrm{Pu}$ & 0.450 & & \\
\hline $\mathrm{Pu}-241$ & $\mathrm{Pu}$ & 0.200 & & \\
\hline Am-242m & $\mathrm{Am}$ & 0.013 & & \\
\hline $\mathrm{Cm}-243$ & $\mathrm{Cm}$ & 0.090 & & \\
\hline $\mathrm{Cm}-245$ & $\mathrm{Cm}$ & 0.030 & & \\
\hline $\mathrm{Cm}-247$ & $\mathrm{Cm}$ & 0.900 & & \\
\hline
\end{tabular}

Note: Table taken from ANSI, 2005. 
Issues of composition

Yoshimochi (2004) described fabrication of a MOX fuel with 3\% americium oxide included. For that work they concluded that they required hot cell operation because handling the gamma-emitting americium in a glovebox was difficult. The fuel pellets were fabricated beginning with typical powder metallurgy - mixing, granulating, and pressing. The apparatus used in this fabrication was housed in stainless steel box enclosures (i.e., caissons) within a hot cell, presumably to confine dust contamination as well as reduce operator dose. The apparatus typically produced uranium oxide fuel and was remotely controlled by an operator at a control panel. The powder was weighed and an organic binder was blended into the mixture inside a ball mill that uses $10-\mathrm{mm}$ diameter tungsten balls. The resulting pellet density of that initial batch was only $88 \%$ of theoretical density after sintering. The cause of the low density was traced to the fact that $\mathrm{UO}_{2}$ and $\mathrm{Am}-\mathrm{PuO}_{2}$ powders have different morphologies and did not uniformly homogenize in the ball mill after the typical 4 hour milling time, despite attempts of enhance blending. Experimentation showed that the mixture required at least 10 hours of milling time to obtain a sintered pellet of $94.5 \%$ theoretical density. This is not a safety problem, but it does lengthen the time that powder form is being handled in the process, and may lead to more dust production. There may be other means besides ball milling available to mix the powders. Another issue occurred during the fabrication work. A large uranium spot was observed in one of the pellets; poor mixing was ruled out since the ball mill time had been more than doubled. The uranium spot was believed to have come from residue from a previous run of the powder feeder for $\mathrm{UO}_{2}$ pellet production. Therefore, complete cleaning of the equipment prior to fabricating batches of actinide bearing fuel would be necessary to prevent residues from previous fuel batches from entering in to the new process.

Croixmarie (2003) also experienced the mixing issue when fabricating americium in magnesia targets. When the densities of the magnesia powder granules and the spheres composed of $\mathrm{Am}, \mathrm{Ce}, \mathrm{Pu}, \mathrm{Y}$, and $\mathrm{Zr}$ oxides were very different, mixing led to agglomeration and segregation. Increasing the magnesia granule size to 50-71 microns produced good mixing and produced pellets with greater than $95 \%$ theoretical density, no cracks, and the preferred random distribution of isolated spheres.

Krellmann (1993) described that MOX fuel pellets needed to be dried very thoroughly to remove any residual moisture prior to placing the pellets in a fuel pin. Moisture would bond well with sub-stoichiometric plutonium oxide, leaving hydrogen trapped in the fuel pin. Then, under reactor core heat and radiolysis conditions the hydrogen would react to form zirconium hydride on the fuel pin walls, leading to localized damage of the pin. Drying over $350 \mathrm{C}$ in vacuum or in a dry inert gas was recommended.

\section{$\underline{\text { Safety and Reliability }}$}

Fullwood $(1980,1984)$ prepared a preliminary risk assessment for a fuel fabrication plant, both a reference MOX plant and a recycle plant with $\mathrm{Am}, \mathrm{Np}$, and $\mathrm{Cm}$ actinides incorporated into the MOX fuel. The MOX plant was postulated to have 1,078 Curies 
per kilogram of fuel powder (mainly from $\mathrm{Pu}-241$ and $\mathrm{Pu}-238$ ) and the recycle plant 1,408 Curies/kilogram (increases mainly from Cm-244, Cm-242, Am-241, and Np-239). The plant capacity was 600 metric tons of heavy metal per year. Preliminary hazards were identified as: powder leaks, filter failures, fire in the powder receiving area, powder overheating during processing, criticality, pellet press hydraulic fluid fire, solvent fire/explosion, pellet grinder failure, and improper fuel pin welding resulting in aerosol release. Scrap recovery in the plant also had several hazards, including criticality concerns, hydrogen explosions, solvent fires, red oil explosions, resin fire/explosion, and filter failures. External events included aircraft crash into the powder area, earthquake, and a tornado that reversed air flow in the facility. The fuel fabrication plant used thick concrete walls and remote handling. Fullwood's conclusion was that the hazard was well handled by the shielding and remote handling design, so the reference and recycle plant risks were identical at 6E-04 fatalities per GWe capacity-year from radiological releases, and industrial risks to workers were 1.1E-02 fatalities per GWe capacity-year. Occupational radiation doses were about equal between operators and maintainers, with most maintenance being performed remotely.

Conclusion. The fuel fabrication industry has enjoyed relatively easy fuel assembly since uranium is a low specific activity material. Moving to mixed oxide fuel increased the radiation hazard because of plutonium isotopes and their emissions, so MOX fuel fabrication required more shielding and enclosures of the process beyond the uranium processes. Moving to actinide inclusion in fuel poses another increasing level of difficulty. The operating experience thus far shows that handling the americium and curium has been performed in hot cells to provide for personnel protection and good confinement against environmental release. Renard (1995) stated that curium could probably not be handled in gloveboxes unless the boxes were specially shielded for that neutron emitter. Americium and curium appear to be the most challenging isotopes to handle during recycling. One recycle introduces a limited amount of radionuclides bred in the core, such as the plutonium isotopes. Additional recycle sessions would increase the concentrations of these radionuclides and their decay products. If a hot cell is used, it appears that multi-recycling fuel fabrication work can be performed safely. If an automated glovebox line is used, extensive glovebox shielding and remote reach tools would have to be provided to accommodate multiple recycling stages. 


\section{Appendix D References}

ANS, 1988. Design Guides for Radioactive Material Handling Facilities and Equipment, American Nuclear Society, La Grange Park, Illinois, 1988, page 152.

ANSI, 2005. American National Standard for Nuclear Criticality Control of Special Actinide Elements, ANSI/ANS-8.15-1981, American National Standards Institute, reaffirmed 2005.

ATSDR, 1990. Toxicological Profile for Plutonium, profile 143, US Department of Health and Human Services, Agency for Toxic Substances and Disease Registry, December 1990.

ATSDR, 1999. Toxicological Profile for Uranium, profile 150, US Department of Health and Human Services, Agency for Toxic Substances and Disease Registry, September 1990 .

ATSDR, 2004. Toxicological Profile for Americium, profile 156, US Department of Health and Human Services, Agency for Toxic Substances and Disease Registry, April 2004.

Batchelor, 1982. K. Bachelor, National Synchrotron Light Source Safety Analysis Report, BNL-51584, Brookhaven National Laboratory, July 1982.

Baum, 2002. E. M. Baum et al., Nuclides and Isotopes, $16^{\text {th }}$ Edition, Knolls Atomic Power Laboratory, 2002.

Bemden, 1981. E. V. Bemden, "Fabrication of Plutonium-Enriched Fuel at Belgionucleaire," Nuclear Technology, 53 (1981) 186-195.

Benedict, 1981. M. Benedict, T. H. Pigford, and H. W. Levi, Nuclear Chemical Engineering, second edition, McGraw-Hill, Inc., New York, 1981, page 369.

Brodsky, 1985. A. Brodsky, A. L. Soong, J. Bell, Radiation Protection Training at Uranium Hexafluoride and Fuel Fabrication Plants, NUREG-1127, US Nuclear Regulatory Commission, May 1985.

Carmack, 2005. W. J. Carmack, private communication, Idaho National Laboratory, July 26, 2005.

Klaassen, 2001. C. D. Klaassen, Casarett and Doull's Toxicology, the Basic Science of Poisons, McGraw-Hill, Inc., New York, 2001, chapter 23.

Cochran, 1999. R. G. Cochran and N. Tsoulfanidis, The Nuclear Fuel Cycle: Analysis and Management, American Nuclear Society, La Grange Park, Illinois, 1999, page 85 . 
Croixmarie, 2003. Y. Croixmarie et al., "Fabrication of transmutation fuels and targets: the ECRIX and CAMIX-COCHIX experience," Journal of Nuclear Materials, 320 (2003) 11-17.

Draulans, 1985. J. Draulans and A. Vandergheynst, "Belgonucleaire automates mixed oxide manufacture," Nuclear Engineering International, 30, number 366 (March 1985) pages 31-33.

Feraday, 1981. M. A. Feraday, "Remote Fabrication of $\left(\mathrm{Th}^{2}{ }^{233} \mathrm{U}\right) \mathrm{O}_{2}$ Pellet-Type Fuels for CANDU Reactors," Nuclear Technology, 53 (1981) 176-185.

Ferguson, 1963. D. E. Ferguson, "ORNL Transuranium Program, the Production of Transuranium Elements," Nuclear Science and Engineering, 17 (1963) 435-437.

Fullwood, 1980. R. R. Fullwood and D. Campbell, Actinide Partitioning-Transmutation Program Final Report, VI. Short-Term Risk Analysis of Reprocessing, Refabrication, and Transportation (Appendix), ORNL/Sub-80/31048/1, appendix to ORNL/TM-6986, also SAI-099-78-PA, Science Applications Inc., January 1980.

Fullwood, 1984. R. R. Fullwood, "Risks Associated with Nuclear Material Recovery and Waste Preparation," Nuclear Safety, 25 (1984) 654-667.

Haggard, 1996. D. L. Haggard, J. E. Tanner, and P. L. Tomeraasen, Determination of the Radioactive Material and Plutonium Holdup in Ducts and Piping in the 325 Building, PNNL-11288, Pacific Northwest National Laboratory, August 1996.

Houser, 2005. H. A. Houser, private communication, Idaho National Laboratory, August 2,2005 .

Krellmann, 1993. J. Krellmann, "Plutonium Processing at the Siemens Hanau Fuel Fabrication Plant," Nuclear Technology, 102 (1993) 18-28.

Leblanc, 1982. J.-M. Leblanc and G. Vanhellemont, "Plutonium-Enriched Thermal Fuel Production Experience in Belgium," Transactions of the American Nuclear Society, 40 (1982) 36-40.

Lederer, 1978. C. M. Lederer et al., Table of Isotopes, $7^{\text {th }}$ edition, John Wiley $\&$ Sons, New York, 1978.

Nof, 1985. S. Y. Nof, Handbook of Industrial Robotics, John Wiley and Sons, New York, 1985, chapter 35 
Renard, 1995. A. Renard, "Actinide Recycling in Fast and Thermal Reactors," in Safety and Environmental Aspects of Partitioning and Transmutation of Actinides and Fission Products, IAEA-TECDOC-783, Vienna, 1995, pages 25-32.

Renard, 1995a. A. Renard et al., "Implications of Plutonium and Americium Recycling on MOX Fuel Fabrication," Proceedings of Global '95, the International Conference on Evaluation of Emerging Nuclear Fuel Cycle Systems, Versailles, France, September 11-14, 1995, pages 1683-1690.

Renard, 1997. A. Renard et al., "Fuel Fabrication Constraints when Recycling Americium," Proceedings of Global '97, the International Conference on Future Nuclear Systems, Yokohama, Japan, October 5-10, 1997, pages 484-488.

Rice, 1994. T. G. Rice, "The processing of oxide reprocessed uranium (REPU) through existing fuel fabrication plants on a trial basis," Nuclear Energy, 33 (1994) 179182.

Robinson, 1969. R. A. Robinson and R. W. Schaich, "Curium Source Fabrication Facility," Proceedings of the $16^{\text {th }}$ Conference on Remote Systems Technology, March 11-13, 1969, Idaho Falls, Idaho, American Nuclear Society, La Grange Park, Illinois, 1969, pages 49-55.

Roepenack, 1987. H. Roepenack, V. W. Schneider and K. Wittmann, "Achieving good experience with MOX co-conversion," Nuclear Engineering International, 32, number 391 (February 1987), 37-38.

Samsel, 1970. G. Samsel, J. Vaane, and E. de Pas, "Three Years of Experience in the Handling of Irradiated Plutonium, Americium, and Curium," RFP-TRANS-133, translation to English of IAEA-SM-125/52, Proceedings of the Symposium on Radiation Safety of Hot Facilities, Saclay, France, October 1969, International Atomic Energy Agency, 1970, pages 497-509.

Yoshimochi, 2004. H. Yoshimochi et al., "Fabrication Technology for MOX Fuel Containing $\mathrm{AmO}_{2}$ by an In-cell Remote Process," Journal of Nuclear Science and Technology, 41 (2004) 850-856.

UN, 2002. World Robotics 2002, United Nations Publication, New York, 2002, page 30.

Wahlquist, 1998. D. R. Wahlquist and R. H. Rigg, Equipment Design Guidelines for Remote Hot Cell Operations, ANL/ED/CP-95878. Argonne National LaboratoryWest, July 1998. 
Weissert, 1968. L. R. Weissert and G. Schileo, Fabrication of Thorium Fuel Elements, American Nuclear Society, Chicago, Illinois, 1968, chapter 8. 